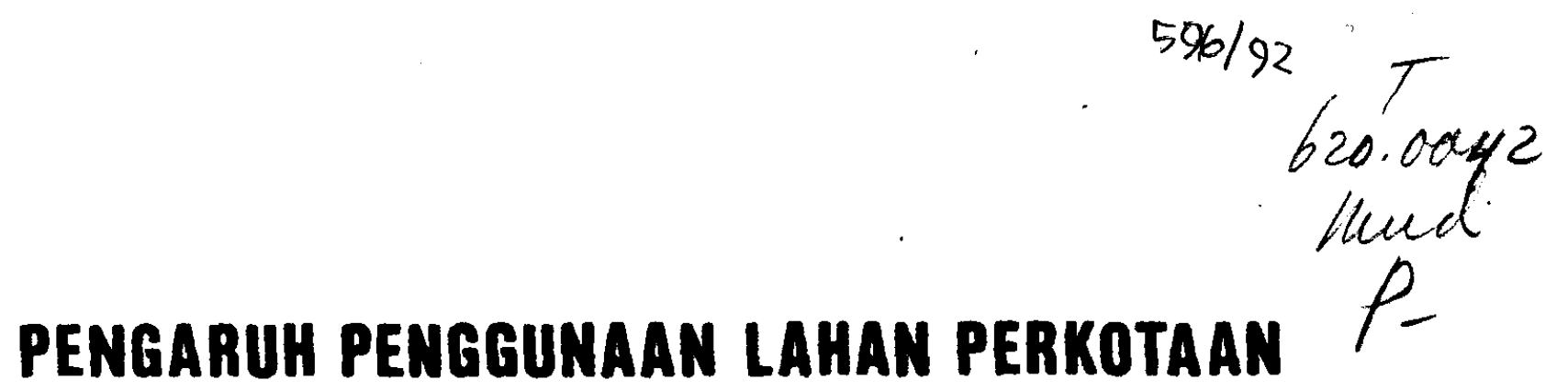

\title{
TERHADAP TEMPERATUR
}

\section{SKRIPSI/TUGAS AKHIR}

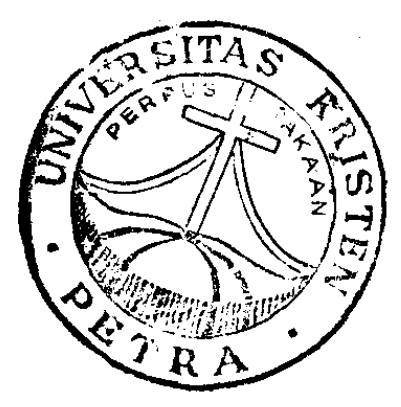

Pada Ujian Program Diploma III Jurusan Teknik Sipil

Fakultas Toknik Universitas Kristen Petra

\section{Oloh:}

Srie Wiwoho Mudjanarko Nrp:13285504

M. Bagus Wijaya

Nrp : 33287528

\section{JURUSAN TEKNIK SIPIL}

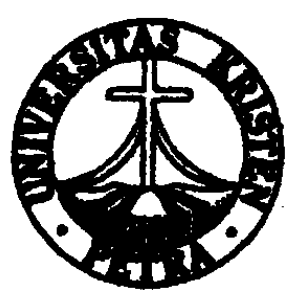

FAKULTAS TEKNIK

UNIVERSITAS KRISTEN PETRA

SURABAYA

1992 


\title{
PENGARUH PENGgunaAN LAHAN PERKotaAN TERHADAP TEMPERATUR
}

\author{
Oleh: \\ Srie Wiwoho Mudjanarko Nrp:1328550.7 \\ M. Bagus Wijaya Nrp:33:?875:8 \\ JURUSAN TEKNIK SIPIL
}

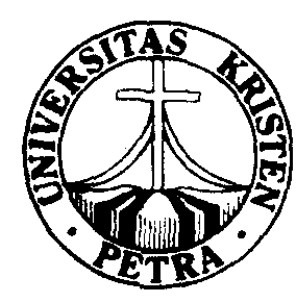

FAKULTAS TEKNIK UNIVERSITAS KRISTEN PETIIA SURABAYA 1992 
Diterima oleh Progran Teknik Sipil Diploma III

Eakultas Teknik

Universitas Kristen Petra

Ketua Tim Penguji,

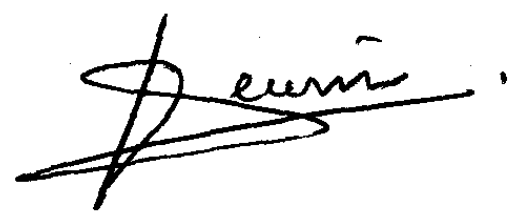

( Ir. Mutradeni Subagio M.Sce )

Pembimbing,

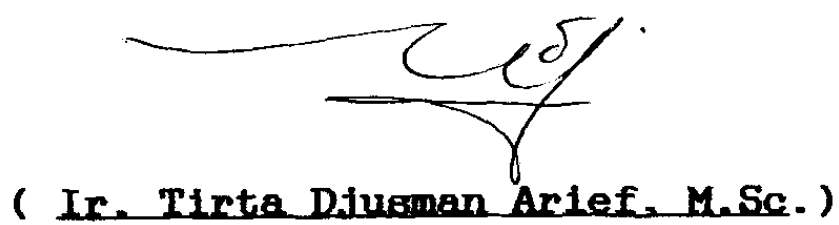

Diusahakan Oleh,

Kepala Program Teknik Sipil Diploma III Surabaya, 6 Februari 1992

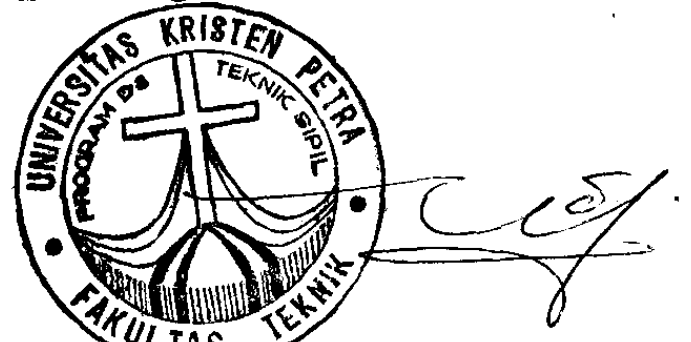

(IAStrete Djusman Arief, M.Sc.) 
Ongen ini monemangken bahwa Skripsi/Tugas hkhir dongen jualul :

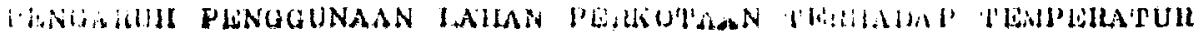

-

1

yaig dibunt oloh mahasiswa-mahasiswa torsobut di bawah ini :

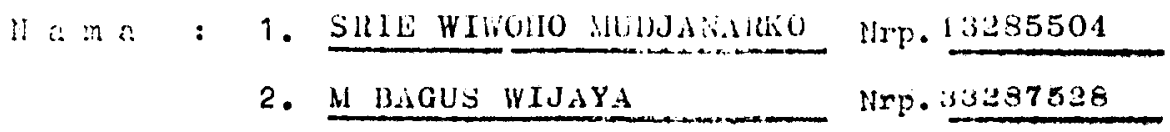

Bidang/Program Studi : DIlLUMA II I

Ysip dibunt berdesarkon Surat Panugasan Boban Akadomik No. 201/3/1/91 traterel

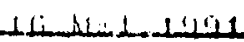

mriampuh Uilian Komprohana1p II. *).
Surabays, \& Livli!l 1992

Doson pambimbiritg skripsi/Tugas nkhir

Ponkinking II, Pombimbluge I,

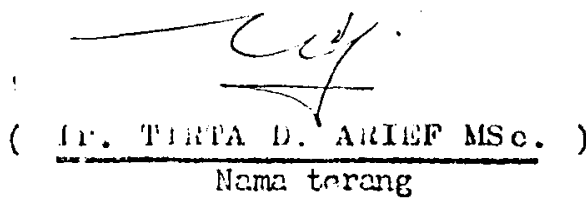

Mongotahut :

Ka Bid./Program Studi DIPLOMA III

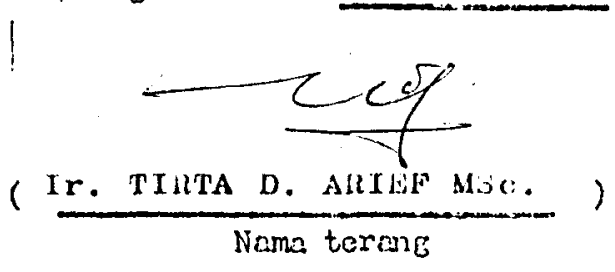

*). Katurazgan :

Pumat Skripai/Tursas Akhir boloh borbantuk fotocopy loposen darl knt1kn/

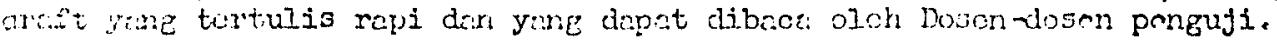

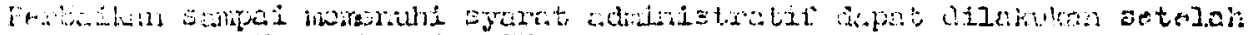

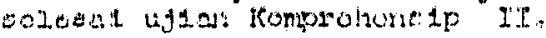

Solfin moneruhi porsyaratan ini, mahasiswa harus monyolosaikan somua matakuisah (termasuk tugas, korja proktok, dlI.) untuk dapat mrngikuti Ujian Kormohensip II. 


\section{KATA PENGANTAR}

Dengan mengucapkan puji syukur kepada Tuhan Yang Maha Esa atas segala rachmat dan bimbinganNya kepada kami sehingga kami dapat menyelesaikan dengan baik tugas akhir ini yang menjadi kewajiban mahasiswa tingkat akhir Fakultas Teknik Sipil Universitas Kristen Petra.

Tidaklah berlebihan kiranya pada kesempatan yang baik ini kami menyampaikan ucapan terima kasih yang sebesarbesarnya kepada :

1. Bapak Ir. Oentoeng, Dekan Fakultas Teknik Universitas Kristen Petra.

2. Bapak Ir. Ruslan Djajadi M.Eng, Ketua Jurusan Teknik Sipil Universitas Kristen Petra.

3. Bapak Ir. Agus A. M.Sc., Sekretaris Jurusan Teknik Sipil Universitas Kristen Petra.

4. Bapak Ir. Tirta D. Arief M.Sc. sebagai Dosen pembimbing tugas akhir.

5. Bapak Drs. Anwarudin M.S. yang banyak membantu hingga terselesaikannya tugas akhir ini.

6. Jawatan Metereologi Dan Geofisika Perak I, Jawatan Metereologi Dan Geofisika Juanda, Satlantas dan Bappeda Kotamadya Surabaya, yang banyak membantu memberikan data - data guna melengkapi tugas akhir ini.

Seperti kata pepatah tiada gading yang tak retak, kami menyadari bahwa hasil tugas akhir ini dan penulisannya masih jauh dari sempurna. Oleh karena itu kami mengharapkan adanya saran dan kritik yang membangun dari para pembaca. 
Akhir kata kami berharap hasil daripada tugas akhir ini dapat bermanfaat bagi kami pribadi maupun para pembaca pada umumnya.

Surabaya, Desember 1991

Penulis 


\section{DATA SKRIPSI / TUGAS AKHIR}

NOMOR

JUDUL

: Pengaruh Penggunaan Lahan Perkotaan

Terhadap Temperatur

NAMA \& NRP MAHASISWA : Srie Wiwoho Mudjanarko / 13285504

DOSEN PEMBIMBING : M. Bagus Wijaya

TAHUN DIBUAT

: 1991

BIDANG STUDI

: $\mathbf{X X}$ KONSTRUKSI

KEAIRAN

PERHQUNCAN

MATA KULIAH PENUNJANG UTAMA :
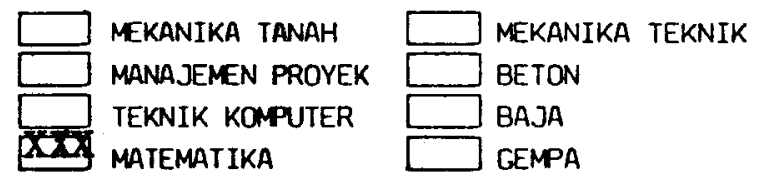

MEKANIKA TEKNIK BAJA GEMPA
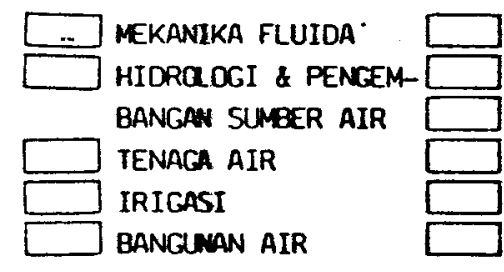
IJALAN RAYA PELABUHAN LAPANCAN TERBANG TEKNIK LALU LINTAS PLANOLGI STABILITAS TANAH

J E N IS:

$\square$ PENELITIAN HASIL LABORATORIUM
$\mathbf{X X}$ PENELITIAN HASIL LAPANGAN
$\square$ PENELITIAN HAL BARU
PERENCANAAN ( PLANNING ) PERENCANAAN ( DESICN ) STUOI KEPUSTAKAAN

A B S T RAK :

Dampak pembangunan yang pesat ierutama di kota besar, meningkatkan penggunaan lahan perkotaan untuk industri, pem bangunan gedung dan perumahan, perluasan jalan yang diseritai peningkatan kendaraan bermotor dan makin berkurangnya lahan kosong/pertanian. Adakah interaksi kenaikkan temperatur dengan perubahan penggunaan lahan perkotaan tersebut.

Dari perhitungan koefisien korelasi menunjukkan interaksi yang kuat antara penggunaan lahan perkotaan dengan tem peratur.

Dari hasil cek tersebut dibuat suatu model interaksi untuk melakukan pengukuran pengaruh perubahan penggunaan lahan perkotaan terhadap temperatur Surabaya di masa kini maupun di masa yang akan datang.

Penelitian ini kiranya dapat dilanjutkan dengan menambah variabel-variabel pendukung peningkatan temperatur se hingga didapat hasil yang lebih sempurna. 
HALAMAN JUDUL

KATA FENGANTAR $\ldots \ldots \ldots \ldots \ldots \ldots \ldots \ldots \ldots$

DAFTAR ISI $\ldots \ldots \ldots \ldots \ldots \ldots \ldots \ldots \ldots \ldots \ldots$ i i i

BAB I FENDAHULUAN $\ldots \ldots \ldots \ldots \ldots \ldots \ldots \ldots \ldots \ldots$

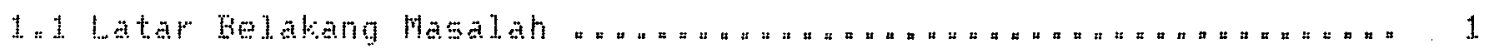

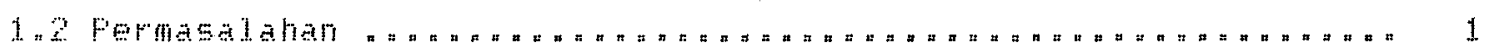

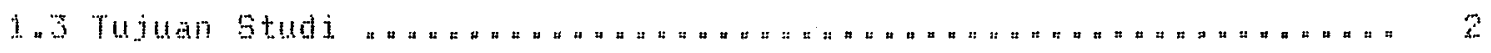

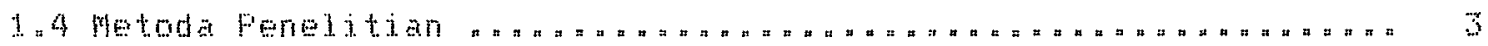

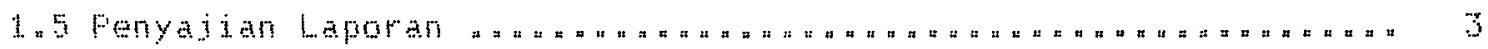

BAB II TEORI PENYELESAIAN $\ldots \ldots \ldots \ldots$

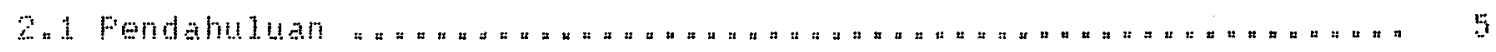

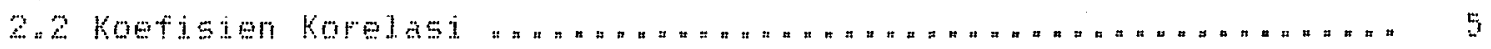

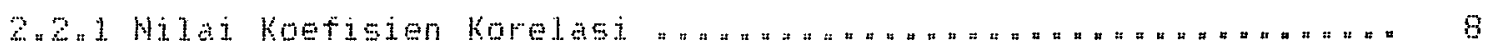

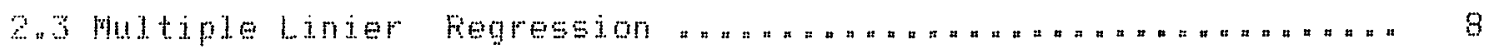

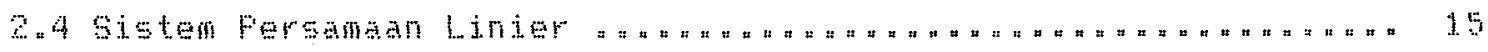

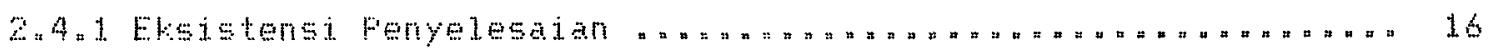

BAE III EVALUASI DATA $\ldots \ldots \ldots \ldots \ldots \ldots \ldots$

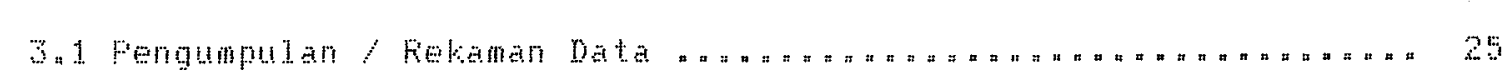

3.

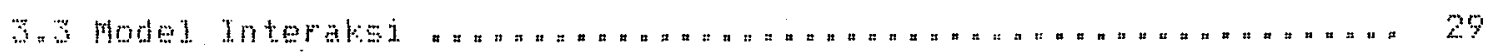

BAE IV KESIMFULAN DAN SARAN SARAN $\ldots \ldots \ldots \ldots$ DAFTAF FUSTAKA $\ldots \ldots \ldots \ldots \ldots \ldots \ldots$ DAFTAR FUSTAKA $\ldots \ldots=\ldots \ldots \ldots \ldots \ldots \ldots \ldots+\ldots \ldots$ LAMFIRAN 


\subsection{Latar Belakang Masalah}

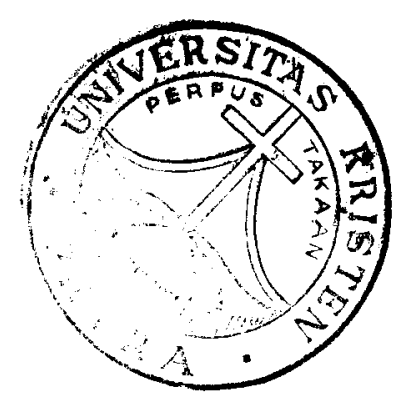

Kemajuan pembangunan yang sangat cepat dewasa ini mengakibatkan perubahan-perubahan besar yang sangat kompleks terutama yang terjadi di kota-kota besar khususnya kota Surabaya kota terbesar kedua di Indonesia ini.

Dinamika pembangunan kota yang terus semakin maju terutama di bidang ekonomi dan industri menjadi daya tarik bagi penduduk sehingga jumlah penduduk dari tahun ke tahun terus bertambah yang disertai dengan meningkatnya tingkat kesejahteraan masyarakat dan mendorong pertumbuhan jumlah kendaraan bermotor yang cukup tinggi. Hal ini berpengaruh pada pola daerah pemukiman dan jumlah luas jalan yang terus bertambah demikian pula daerah - daerah untuk industri.

\subsection{Permasalahan}

Industrialisasi di kota - kota besar membawa dampak berupa meningkatnya urbanisasi, lahan-lahan industri dan sarana-prasarana transportasi di perkotaan. Ada kecenderungan bahwa berkurangnya tanah pertanian, tanah kosong, taman dan meningkatnya jumlah kendaraan menyebabkan temperatur kota bertambah tinggi. Permasalahannya apakah pendapat tersebut benar ? Kalau benar faktor apa saja yang menegang peran atas kenaikkan temperatur tersebut dan 
bagaimana interaksi antara faktor-faktor tersebut dengan temperatur.

\subsection{Tujuan Studi}

Untuk membuktikan benar salahnya pendapat tersebut diatas perlu dilakukan suatu studi. Seandainya temperatur kota dipengaruhi oleh kualitas dan kuantitas sarana dan prasarananya maka interaksi keduanya bisa dijabarkan dalam sebuah model.

Oleh karena itu tujuan utama studi ini adalah : -membuat model interaksi antara temperatur kota Surabaya dengan sarana dan prasarananya yang berpengaruh dan berkorelasi dengan temperatur.

-bila model interaksi sudah terbentuk maka evaluasi temperatur di masa mendatang yang disebabkan oleh adanya perubahan-perubahan sarana dan prasarana kota bisa didasarkan atas model tersebut.

Maka tujuan kedua studi ini adalah aplikasi model interaksi untuk ( 1 ) prediksi temperatur Surabaya pada kurun waktu tertentu, misalkan tahun 2000 dan ( 2 ) melihat seberapa jauh perubahan temperatur yang terjadi apabila suatu prasarana kota Surabaya diganti misalkan lokasi Kebun Bibit kota Surabaya dibuat gedung pertokoan / supermaket. 


\subsection{Metoda Penelitian}

Temperatur kota secara alami merupakan besaran yang tidak tetap dari waktu ke waktu dan dari satu titik ke titik yang lain sehingga merupakan besaran acak ( random variabel). Oleh karena itu besaran-besaran yang terlibat juga merupakan besaran acak maka metode yang sesuai dengan kondisi ini adalah metode statistik determinant.

Langkah - langkah yang dilakukan adalah :

- mengumpulkan data record ( rekaman data).

- mencari keterikatan atau korelasi antara faktor-faktor yang ditinjau dengan temperatur.

- penyelesaian data-data yang berkorelasi dengan temperatur berdasar teori regresi linier banyak variabel.

- membentuk suatu model interaksi dan aplikasinya.

\subsection{Penyajian Laporan}

Di dalam penyajian laporan tugas akhir ini kami bahas dalam beberapa bab pembahasan dimana sebelumnya terlebih dahulu kami bahas didalam bab I mengenai permasalahan yang dihadapi yakni untuk mengetahui pengaruh faktor-faktor yang ditinjau terhadap kenaikkan dan penurunan temperatur, tujuan studi dan metoda penelitian yang digunakan dalam penulisan laporan ini. Bab II mengenai pembahasan teoriteori penyelesaian yang digunakan antara lain membahas koefisien korelasi, regresi linier banyak variabel dan teori penyelesaian persamaan simultan di dalam hal ini 
salah satu teori yang kami gunakan adalah metoda Persamaan Linier. Bab III berisi evaluasi data-data sampai diperoleh model interaksi yang menyatakan hubungan temperatur dengan sarana dan prasarana kota Surabaya. Dalam bab ini disajikan pula aplikasi model yang didapat dengan mengambil beberapa contoh atau kasus. Sedangkan kesimpulan dan saran untuk pengembangan studi ini dikemudian hari kami sajikan dalam bab IV. 


\section{EAE I I \\ TEORI PENYEIESAIAN}

\subsection{Pendahuluan}

Telah diuraikan di bab I, studi ini terdiri dari beberapa tahapan. Dalam masing-masing tahapan diperlukan prosedur yang berbeda sesuai dengan yang diperlukan dalam tahapan tersebut.

Oleh karena itu sebelum memenuhi tahap evaluasi data akan dipaparkan teori-teori yang dipergunakan dengan maksud agar lebih mudah dimengerti dasar pemikiran mengapa teori tersebut yang dipergunakan.

\subsection{Koefisien korelasi}

Teoritis, tiap fenomena alam bisa dinyatakan sebagai besaran acak ( random variabel). Seringkali bahwa suatu fenomena dipengaruhi oleh satu atau lebih fenomena yang lain, tetapi seberapa jauh sumbangan suatu fenomena terhadap fenomena yang ditinjau tergantung pada keterikatan fenomena yang bersangkutan. Derajat keterikatan ini dalam statistik dinyatakan dalam koefisien korelasi. Koefisien korelasi dari besaran acak $X$ dan $Y$ didefinisikan sebagai perbandingan antara ko-varian ( $X, Y$ ) terhadap deviasi standart masing-masing besaran acak, atau 


$$
\uparrow_{x y}=\frac{\operatorname{cov}(x, y)}{\sigma x \sigma y}
$$

di mana :

$\operatorname{cov}(x, y)=1 / n \sum(x-\bar{x})(y-\bar{y})$

$\sigma x^{2}=1 / n \sum(x-\bar{x})^{2}=1 / n \sum(x-\bar{x})(x-\bar{x})$

$\sigma y^{2}=1 / n \sum(y-\bar{y})^{2}=1 / n \sum(y-\bar{y})(y-\bar{y}) \quad(1 c)$

misal $\mathrm{x}=\mathrm{y}$;

persamaan ( $1 \mathrm{a}$ ), ( $1 \mathrm{~b}$ ) dan ( 1c) menunjukkan kesamaan maka dapat dipandang sebagai variasi gabungan $x$ dan $y$. Dengan demikian nilai / bisa dipandang sebagai tingkat keterkaitan $\mathrm{x}$ terhadap $\mathrm{y}$ dan sebaliknya.

Dengan mensubsitusikan persamaan $1 \mathrm{a}, 1 \mathrm{~b}$ dan $1 \mathrm{c}$ ke dalam persamaan 1 didapat :

$$
\Gamma=\frac{N \sum X Y-\Sigma Y}{\sqrt{ }\left\{N \Sigma X^{2}-\Sigma X^{2}\right\} \cdot\left\{N \Sigma Y^{2}-\Sigma Y^{2}\right\}}
$$

Persamaan ( 2 ) lebih operasional dibandingkan persamaan ( 1 ) maka data - data yang akan dihitung, dalam hal ini $X$ sebagai faktor - faktor yang mempengaruhi temperatur dan variabel $Y$ sebagai temperatur dapat diselesaikan secara tabelaris.

Berikut disajikan contoh perhitungan menentukan koefisien korelasi antara temperatur kota Surabaya dengan 
luas bangunan gedung (tabel 3.1 ). Hasil perhitungan menunjukkan koefisien korelasi antara temperatur kota Surabaya dan luas bangunan gedung adalah 0,85 .

TAEEL 3.1. PERHITUMGAN KGEFISIEN KORELAgI ANTARA TEMPERTTUR DENGAN BANGLNAN GEDUNG

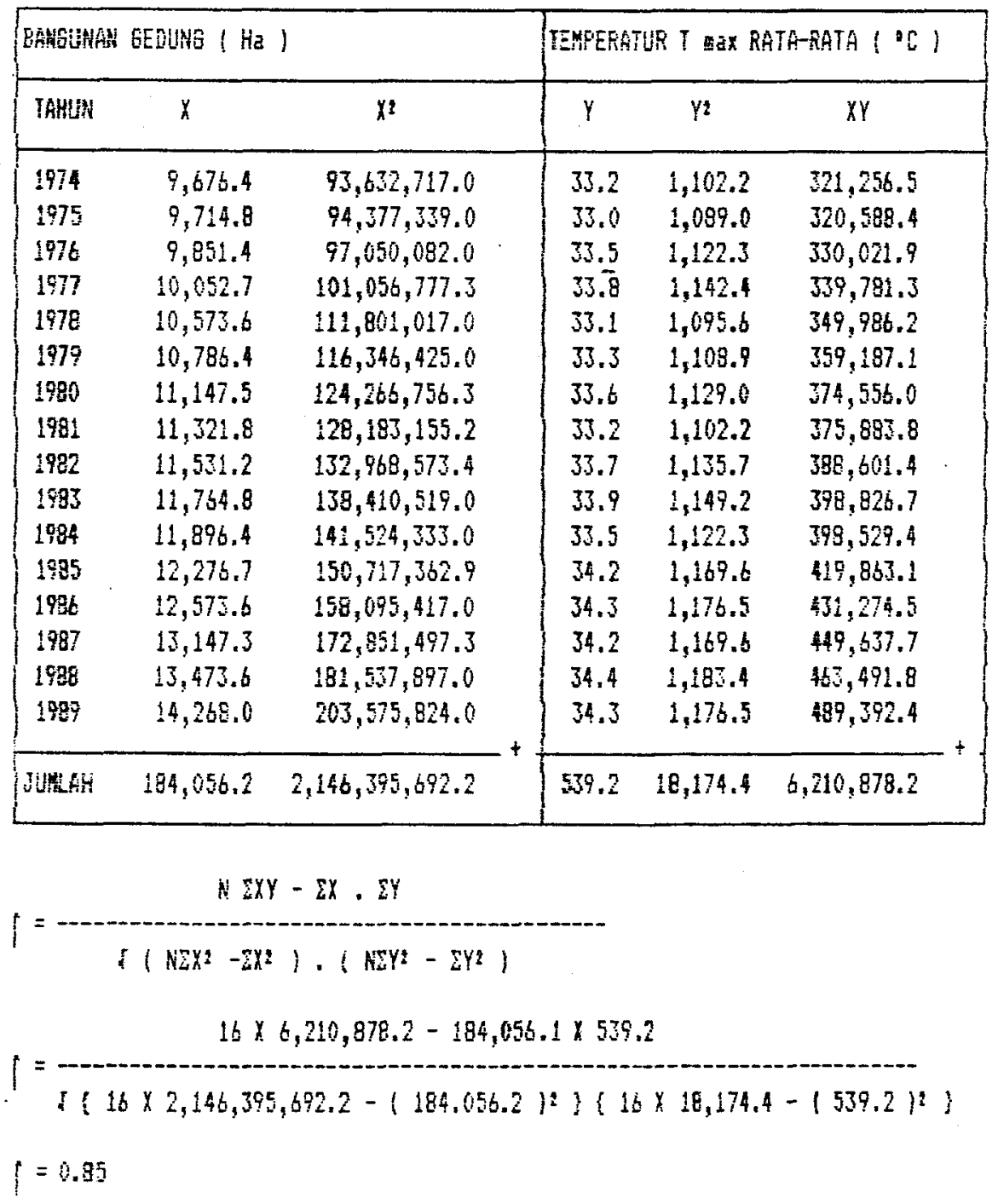




\subsubsection{Nilai Koefisien Korelasi}

Secara umum besaran acak X bisa sejalan atau berlawanan dengan besaran acak $Y$. $X$ dan $Y$ sejalan bila nilai koefisien korelasinya positif dan berlawanan bila nilai koefisien korelasinya negatif. Tapi nilai mutlak dari 「 adalah antara 0 sampai 1 .

Dari teori statistik, $\int_{x y}=0$ dapat dinyatakan bahwa variabel $X$ dan $Y$ tidak berkorelasi dan $\left|\int_{x y}\right|=1$ menyatakan korelasi $X$ dan $Y$ sangat erat. Dalam kenyataan [xy berkisar antara 0 dan 1 sehingga untuk menentukkan bahwa suatu fenomenan yang ditinjau diperlukan batasan nilai $f$. Dalam statistik korelasi besaran acak $X$ dan.$Y$ cukup berarti ( significant) bila nilai :

$$
\Gamma_{x y}>0,7
$$

Maka untuk selanjutnya batasan ini dipakai sebagai dasar penentuan faktor-faktor yang dievaluasi sehubungan dengan temperatur kota Surabaya ( Ang, Ahs, And Tang, WH , Probability Concepts In Enginnering Planning And Design Volume I, Basic Principle, John Wileyand Sons, 1984 ).

\subsection{REGRESI LINIER BANYAK VARIABEL \\ ( MULTIPLE LINEAR REGRFSSION )}

Seringkali terjadi satu variabel tak bebas ( dependent Variabel) tergantung pada lebih dari satu variabel bebas ( independent variabel) seperti halnya temperatur kota yang dipengaruhi berbagai sarana dan prasarananya. Dalam 
hal ini untuk mendapatkan model interaksi antara variabelvariabel tersebut bisa digunakan regresi linier banyak variabel ( multi variabel linier regression). Bila y adalah variabel tak bebas dan $x_{i}$, di mana $i=1, \ldots, m$ adalah fungsi bebas maka:

$\left(y \mid x_{1}, \ldots, x_{m}\right)=\beta_{0}+\beta_{1} x_{1}+\ldots+\beta_{n} x_{m} \quad(2.1)$

di mana $\beta_{i}, i=0,1, \ldots, m$ adalah konstanta

Diasumsikan pula bahwa varian y adalah konstan, maka :

$\operatorname{Var}\left(y \mid x_{i}, \ldots, x_{m}\right): \sigma^{2}$.

Selanjutnya, analisis regresi merupakan prosedur untuk menetapkan nilai $\beta_{i}, i=0, \ldots, m$ berdasarkan data rekaman $\left(x_{1 i}, x_{2 i}, \ldots, x_{m i}, y_{i}\right), i=1, \ldots, n$

Maka dari persamaan ( 2.1 ) bisa ditentukan :

$$
\begin{aligned}
\Sigma\left(z \mid x_{1}, \ldots, x_{m}\right)=a & +\beta_{1}\left(x_{1}-\bar{x}_{1}\right)+\ldots \\
& +\beta_{m}\left(x_{m}-\bar{x}_{m}\right)
\end{aligned}
$$

di mana :

$\Sigma\left(y \mid x_{1}, \ldots, x_{m}\right)=$ nilai y yang diharapkan

$\overline{\mathbf{x}}_{\mathbf{i}}=$ nilai rata-rata data rekaman

$\alpha=$ konstanta

Jumlah kwadrat galat untuk satu'himpunan $\mathrm{n}$ data adalah

$$
\begin{aligned}
\delta^{2} & =\Sigma\left(y_{i}-y_{i}\right)^{2} \\
& =\Sigma\left\{\left(y_{i}-a-\beta_{1}\left(x_{1 i}-\bar{x}_{1}\right)\right)-\ldots-\beta_{m}\left(x_{m i}-\bar{x}_{m}\right)\right\}^{2}(2.4)
\end{aligned}
$$

Untuk menentukan $\alpha \operatorname{dan} \beta_{1, j}=1, \ldots, m, \delta^{2}$ dibuat 
minimum maka :

$d \delta^{2} / d y=0$

dan

$\mathrm{d}^{2} / \mathrm{dx} x_{j}=0 \quad j=1, \ldots, m$

atau

$\mathrm{d} \delta^{2} / \mathrm{d} \alpha=2 \Sigma\left[\mathrm{y}_{\mathbf{i}}-\bar{\alpha}-\bar{\beta}_{1}\left(\mathrm{x}_{1 \mathrm{i}}-\overline{\mathrm{x}}_{1}\right)-\ldots-\right.$

$$
\left.\bar{\beta}_{\mathbf{m}}\left(x_{m i}-\bar{x}_{m}\right)\right]=0 \quad(2.6 .8)
$$

$\mathrm{d} \delta^{2} / \mathrm{d} \beta_{1}=2 \Sigma\left[\left[y_{i}-\bar{\alpha}-\bar{\beta}_{1}\left(x_{1 i}-\bar{x}_{1}\right)-\ldots-\right.\right.$

$$
\left.\left.\bar{\beta}_{m}\left(x_{m i}-\bar{x}_{m}\right)\right]\left(x_{1 i}-\bar{x}_{1}\right)\right\}=0 \quad(2.6 . b)
$$

$$
\begin{aligned}
& \mathrm{d} \delta^{2} / \mathrm{d} \beta_{\mathrm{m}}=2 \sum\left\{\left[\mathrm{y}_{\mathbf{i}}-\bar{\alpha}-\bar{\beta}_{1}\left(\mathrm{x}_{1 i}-\bar{x}_{1}\right)-\ldots-\right.\right. \\
&\left.\bar{\beta}_{\mathrm{m}}\left(\mathrm{x}_{\mathrm{mi}}-\bar{x}_{\mathrm{m}}\right]\left(\mathrm{x}_{\mathrm{mi}}-\bar{x}_{\mathrm{m}}\right)\right\}=0 \quad(2.6 . \mathrm{c})
\end{aligned}
$$

Dari persamaan 2.6a didapat :

$$
y_{i}-\bar{\alpha}-\bar{\beta} \Sigma\left(x_{1 i}-\bar{x}_{1}\right)-\ldots-\bar{\beta}_{m} \Sigma\left(x_{m i}-\bar{x}_{m}\right)=0
$$

karena

$$
\begin{aligned}
& \Sigma\left(x_{1 i}-\bar{x}_{1}\right)=\ldots=\Sigma\left(x_{m i}-\bar{x}_{m}\right)=0 \text {, maka didapat } \\
& \begin{aligned}
a & =\Sigma y_{i} / \mathbf{n} \\
& =\bar{y}
\end{aligned}
\end{aligned}
$$


Dengan mensubsitusikan nilai $\alpha$ ke persamaan 2.6.b dan seterusnya didapatkan

$\bar{\beta}_{1} \Sigma\left(x_{1 i}-\bar{x}_{1}\right)^{2}+\bar{\beta}_{2} \Sigma\left(x_{1 i}-\bar{x}_{1}\right)\left(x_{2 i}-\bar{x}_{2}\right)+\ldots$

$\bar{\beta}_{m} \Sigma\left(x_{1 i}-\bar{x}_{1}\right)\left(x_{m i}-\bar{x}_{m}\right)=\Sigma\left(x_{1 i}-\bar{x}_{1}\right)\left(y_{i}-\bar{y}\right)$

$\bar{\beta}_{1} \Sigma\left(x_{m i}-\bar{x}_{m}\right)\left(x_{1 i}-\bar{x}_{1}\right)+$

$\bar{\beta}_{2} \Sigma\left(x_{m i}-\bar{x}_{m}\right)\left(x_{2 i}-\bar{x}_{2}\right)+\ldots+$

$\bar{\beta}_{m} \Sigma\left(x_{m i}-\bar{x}_{m}\right)^{2}=\Sigma\left(x_{m i}-\bar{x}_{m}^{-}\right)\left(y_{i}-\bar{y}\right) \quad(2.7)$

$\operatorname{Var}\left(y \mid x_{i}, \ldots, x_{m}\right)$ merupakan tolok ukur dari penyimpangan fungsi regresi. Sebuah pendekatan adalah sebagai berikut ;

$S^{2} Y \mid x_{1}, \ldots, x_{m}=\frac{\delta^{2}}{n-1}$

atau

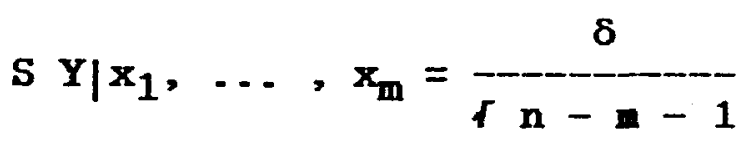

Dari persamaan $(2.8)$ terlihat bahwa $n>m+1$. Bila y terdiri hasil normal maka dengan diketahui $\Sigma$ (y) dan $\Sigma$ y ditetapkan nilai $y$ berdasarkan tingkat keyakinan dan menghitung probabilitas nilai $\mathrm{y}$. 
Contoh : perhitungan dengan cara Regresi Linier Banyak Variabel.

Suatu faktor penting dalam memperkirakan kedalaman pembekuan untuk perencanaan perkerasan jalan adalah suhu tahunan purata dari lokasi yang ditinjau. Pencatatan suhu tahunan purata pada 10 stasiun cuaca yang berlainan di West Virginia diikhtisarkan dalam Tabel 2.3.1.

Karena lapisan perkerasan dapat dibangun pada beberapa lokasi dalam negara bagian tersebut, di mana catatan suhu mungkin tidak tersedia, digunakan untuk memperkirakan suhu tahunan purata lokal yang didasarkan atas ketinggian dan lintang, dengan menggunakan informasi dalam Tabel 2.3.1. Untuk itu, diasumsikan persamaan berikut :

$\Sigma\left(Y \mid x_{1}, x_{2}\right)=\beta_{0}+\beta_{1} x_{1}+\beta_{2} x_{2}$

di mana :

$\mathrm{Y}=$ suhu tahunan purata, dalam ${ }^{\circ} \mathrm{F}$.

$x_{1}=$ ketinggian di atas muka laut, dalam ft.

$\mathrm{x}_{2}=$ lintang utara, dalam derajat. 
Tabel 2.3.1 Suhu Tahunan Purata di West Virginia Data dari Moulton dan Schaub

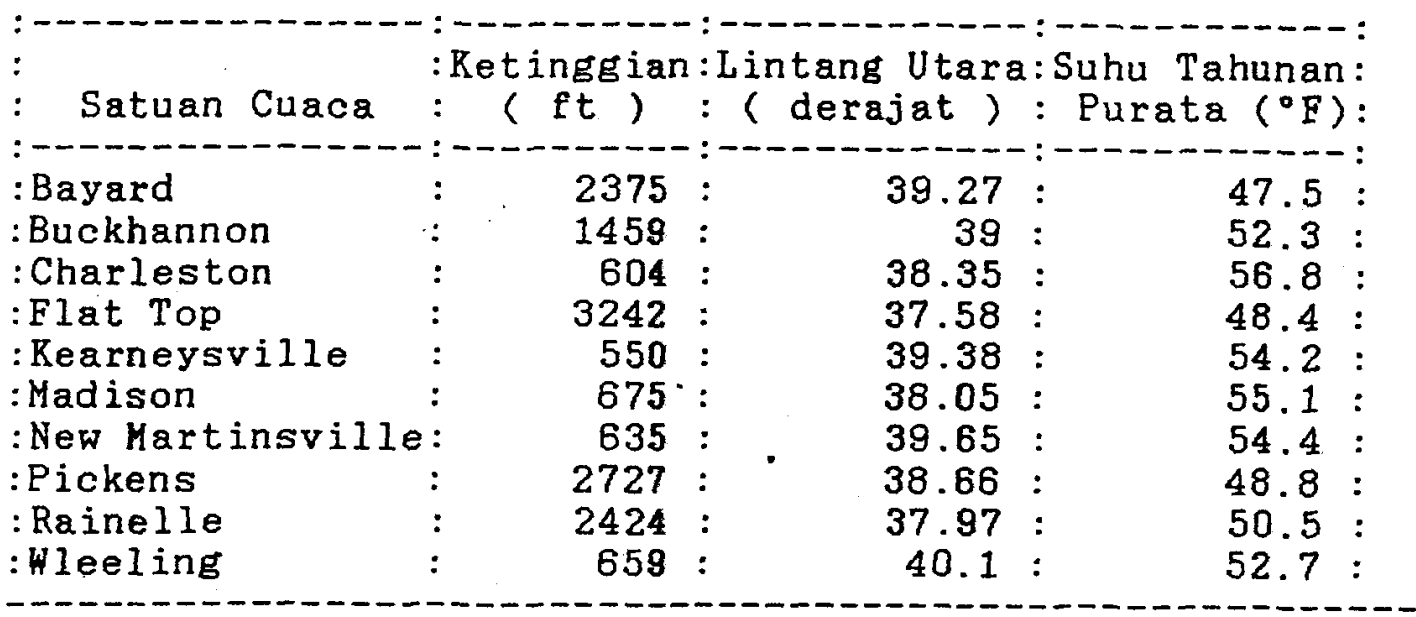

Tabel 2.3.2 Perhitungan Regresi Variabel Banyak Secara Tabel

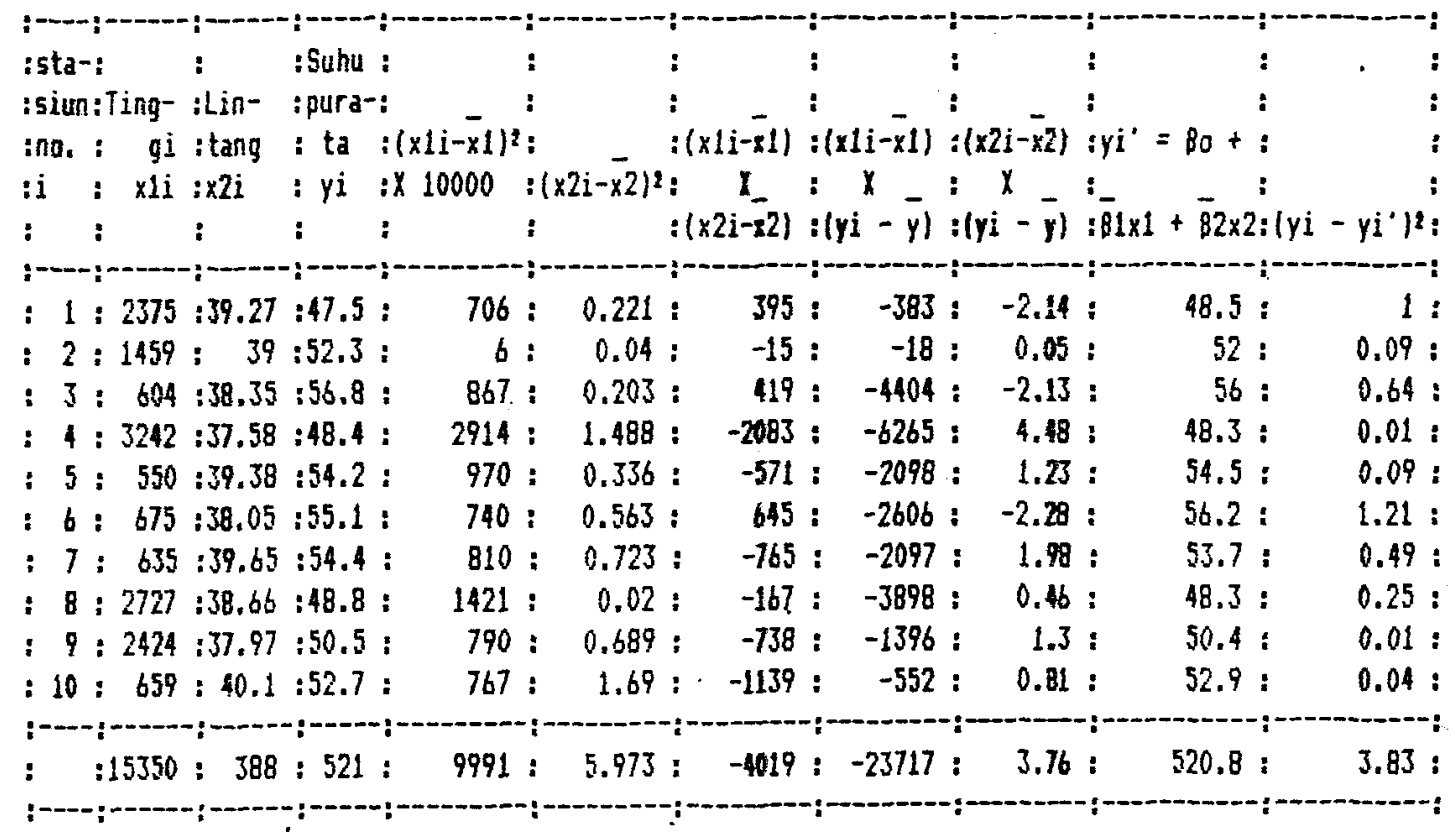




$$
\begin{aligned}
& \bar{x}_{1}=15350 / 10=1535 \\
& \bar{x}_{2}=388,01 / 10=38,80 \\
& \bar{a}=\bar{y}=520,7 / 10=52,07
\end{aligned}
$$$$
s_{y}{ }^{2}=1 / 9 \sum\left(y_{i}-y\right)^{2}
$$$$
S^{2} \bar{Y} \mid x 1, x 2=3,83 / 10-2-1
$$$$
=0,547
$$$$
=89,48 / 9=9,94
$$$$
s_{Y}^{-} \mid \times 1, \times 2=10,547
$$$$
=0,74
$$$$
-r^{2}=1-0,547 / 9,945
$$$$
=0,945
$$

$$
\begin{aligned}
& 9991000 \bar{\beta}_{1}-4019 \bar{\beta}_{2}=-2717 \overline{1} \\
& -4019 \bar{\beta}_{1}+5,973 \bar{\beta}_{2}=3,76 \\
& \bar{\beta}_{1}=\frac{\operatorname{det}\left[\begin{array}{rr}
-2717 & -4019 \\
3,76 & 5,973
\end{array}\right]}{\operatorname{det}\left[\begin{array}{ll}
9991000 & -4019 \\
-4019 & 5,973
\end{array}\right]}=-0,0034 \\
& \bar{\beta}_{2}=\frac{\operatorname{det}\left[\begin{array}{lr}
9991000 & -27171 \\
-4019 & 3,76
\end{array}\right]}{43520000}=-1,65 \\
& \bar{\beta}_{O}=52,07+0,0034 \times 1535+1,65 \times 38,80 \\
& =121,3
\end{aligned}
$$

dari sini didapatkan persamaan hasil sebagai berikut : $E\left(Y \mid X_{1}, X_{2}\right)=121,3-0,1134 x_{1}-1,65 x_{2}$ 


\subsection{Sistem Persanaan Linier}

Dari persamaan ( 2.7 ) terlihat bahwa proses regresi linier banyak variabel terdirt atas m persamaan dengan $n$ perubah $: \mathrm{x}_{1}, \mathrm{x}_{2}, \ldots, \mathrm{x}_{\mathrm{n}}$ yaitu :

$$
\begin{aligned}
& a_{11} x_{1}+a_{12} x_{2}+\ldots+a_{m} x_{n}=b_{1} \\
& a_{21} x_{1}+a_{22} x_{2}+\ldots+a_{2 m} x_{n}=b_{2} \\
& a_{m 1} x_{1}+a_{m 2} x_{2}+\ldots+a_{m n} x_{n}=b_{m}
\end{aligned}
$$

atau dapat ditulis dalam bentuk matrix

$$
\begin{array}{r}
{\left[\begin{array}{cccc}
a_{11} & a_{12} & \cdots & a_{1 n} \\
a_{21} & a_{22} & \cdots & a_{2 n} \\
\cdot & \cdot & & \cdot \\
a_{m 1} & a_{m 2} & \cdots & a_{m n}
\end{array}\right]} \\
A
\end{array}
$$

Sistem persamaan linier inl dapat dibedakan atas 2 yaitu :

1. Sistem persamaan linier homogen yaitu apabila persamaan tersebut mempunyai nilai $\mathrm{B}=0$ contoh;

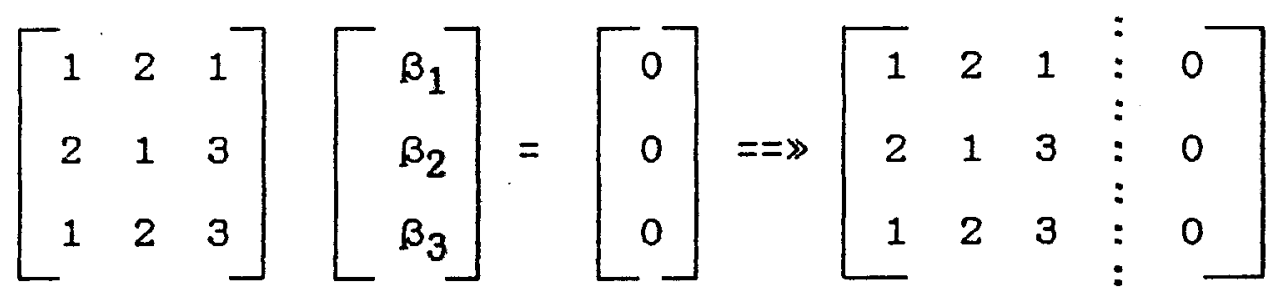


2. Sistem persamaan linier Non Homogen yaitu apabila persamaan tersebut mempunyai nilai B tidak sama $=0$ contoh ;

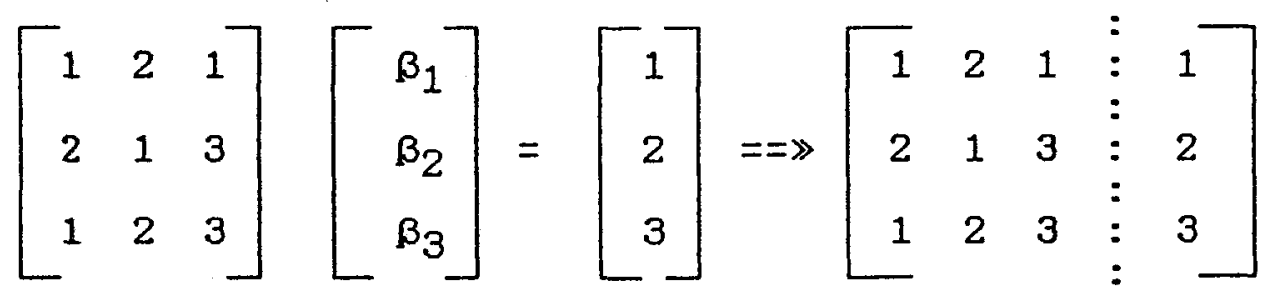

\subsubsection{Eksistensi Penyelesaian}

Sebelum memulai perhitungan dengan sistem persamaan linier non homogen harus diketahui terlebih dahulu ada tidaknya penyelesaian dari suatu sistem persamaan linier tersebut yaitu dengan melihat dari rank matrik $\left(\mathbf{A}^{\circ}\right)$

Adapun rank matrik adalah tingkat tertinggi dari suatu matrik yang diterminantnya tidak semuanya nol.

Untuk menentukkan rank suatu matrik bisa diperoleh dengan cara sebagai berikut :

- Me"nol"kan sebanyak mungkin baris atau kolom dengan menggunakan operasi baris atau kolom sehingga terbentuk suatu matrik yang elemen-elemennya tidak bisa di"nol"kan lagi.

Setelah rank matrik dapat diketahui maka persamaan linier tersebut akan mempunyai kemungkinan-kemungkinan penyelesaian sebagai berikut : 
untuk m $<\mathbf{n}$

$r(A)=r(A / B)====>$ banyak penyelesaian

$r(A)<r(A / B)====>$ tidak mempunyai penyelesaian

untuk $\mathbf{m}=\mathbf{n}$

$r(A)=r(A / B)=n====>$ penyelesaian tunggal

$r(A)=r(A / B)<n====>$ banyak penyelesaian

$r(A)<r(A / B) \quad====>$ tidak mempunyai penyelesaian

untuk m $>\mathbf{n}$

$r(A)=r(A / B)=n====>$ penyelesaian tunggal

$r(A)=r(A / B)<n====>$ banyak penyelesaian

$r(A)<r(A / B) \quad===\Rightarrow$ tidak mempunyai penyelesaian

Untuk jelasnya sistem persamaan linier tersebut di atas berikut ini akan kami sajikan sebuah contoh.

Contoh :

( data - data diambil dari hasil perhitungan lampiran 2 dan 3 ).

$\begin{array}{llll}811=39,48 & 621=42,43 & \delta 31=202,64 & \alpha 1=9,96 \\ 812=42,43 & 822=75,07 & 832=319,84 & \alpha 2=11,87 \\ \delta 13=202,64 & 823=319,84 & 833=1516,24 & \alpha 3=56,9\end{array}$

dapat ditulis dalam bentuk :

$39,48 \quad \beta_{1}+42,43 \quad \beta_{2}+202,64 \quad \beta_{3}=9,96$

$42,43 \beta_{1}+75,07 \quad \beta_{2}+319,84 \quad \beta_{3}=11,87$

$202,64 \beta_{1}+319,84 \beta_{2}+1516,24 \beta_{3}=56,90$

atau dalam bentuk penulisan matrik sebagai berikut : 


$A=\left[\begin{array}{rrr}39,48 & 42,43 & 202,64 \\ 42,43 & 75,07 & 319,84 \\ 202,64 & 319,84 & 1516,24\end{array}\right]$

dan

\begin{tabular}{|c|c|c|c|c|}
\hline \multirow{3}{*}{$A / B=$} & 39,48 & 42,43 & 202,64 & 9,96 \\
\hline & 42,43 & 75,07 & 319,84 & 11,87 \\
\hline & 202,64 & 319,84 & 1516,24 & 56,90 \\
\hline
\end{tabular}

sebelum dilakukan perhitungan persamaan linier maka yang harus dilakukan adalah mencari nilai rank matrik dari :

$\left.\begin{array}{l}m=3 \quad n=3 \\ r(A)=3 \\ r(A / B)=3\end{array}\right] \quad$ Penyelesaian tunggal

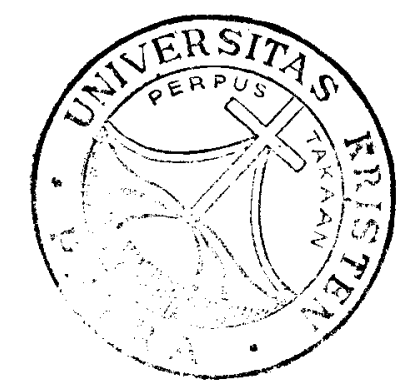

$\left[\begin{array}{rrr}39,48 & 42,43 & 202, \overline{64} \\ 42,43 & 75,07 & 319,84 \\ 202,64 & 319,84 & 1516,24\end{array}\right]$

(A)

adapun langkah-langkahnya :

elemen ( 2,1$)$ dan $(3,1)$ di"nol"kan yaitu dengan cara sebagai berikut :

$B_{2 i}=B_{1 i^{\prime}} \times\left(-B_{21} / B_{11}\right)^{\prime}+B_{2 i^{\prime}}$ atau dapat ditulis dalam bentuk notasi $B_{21}(-42,43 / 39,48)$

$B_{3 i}=B_{11^{\prime}} \times\left(-B_{31} / B_{11}\right)^{\prime}+B_{3 i^{\prime}}$ atau dapat ditulis dalam bentuk notasi $\mathrm{B}_{31}(-202,64 / 39,48)$ 
sehingga didapat bentuk matrik :

$\mathrm{B}_{31}(-202,64 / 39,48)\left[\begin{array}{ccc}39,48 & 42,43 & 202,64 \\ 0 & 29,47 & 102,06 \\ 0 & 102,06 & 476,14\end{array}\right]\left(A_{1}\right)$

langkah selanjutnya,

dengan me"nol"kan elemen matrik ( 1,2) dan $(3,2)$ dengan cara:

$B_{1 i}=B_{2 i} \times\left(-B_{12} / B_{22}\right)^{\prime}+B_{1 i}$ atau dapat ditulis dalam bentuk notasi $B_{12}(-42,43 / 29,47)$

$B_{3 i}=B_{2 i} \times\left(-B_{32} / B_{22}\right)^{\prime}+B_{3 i}$ atau dapat ditulis dalam bentuk notasi $B_{32}(-102,06 / 29,47)$

sehingga menghasilkan matrik sebagai berikut : .

$\mathrm{B}_{12}(-42,43 / 29,47)$
$\mathrm{B}_{32}(-102,06 / 29,47)$$\left[\begin{array}{ccc}39,48 & 0 & 55, \overline{70} \\ 0 & 29,47 & 102,06 \\ 0 & 0 & 122,69\end{array}\right]\left(A_{2}\right)$

kemudian dilanjutkan me"nol"kan elemen (1,3) dengan cara: $K_{3 i}=K_{1 i} \times\left(-K_{31} / K_{11}\right)^{\prime}+K_{3 i}$ atau dapat ditulis dalam bentuk notasi $k_{31}(-55,7 / 39,48)$

sehingga menghasilkan matrik sebagai berikut : 
$B_{31}(-55,70 / 39,48)\left[\begin{array}{ccr}39,48 & 0 & 0 \\ 0 & 29,47 & 102,06 \\ 0 & 0 & 122,69\end{array}\right] \quad\left(A_{3}\right)$

kemudian me"nol"kan elemen ( 2,3 ) dengan cara:

$K_{3 i}=K_{2 i^{-}} \times\left(-K_{32} / K_{22}\right)^{\prime}+K_{3 i}$ atau dapat ditulis dalam bentuk notasi $\mathrm{K}_{32}(-102,06 / 29,47)$

sehingga didapat matrik sebagai berikut :

$\mathrm{K}_{32}(-102,06 / 29,47)\left[\begin{array}{ccc}39,48 & 0 & 0 \\ 0 & 29,47 & 0 \\ 0 & 0 & 122,69\end{array}\right] \quad\left(A_{4}\right)$

jadi $r(A)=3$

\section{keterangan :}

B.. = operasi baris

R.. = operasi kolom

$B_{1 i}=$ yang dioperasi baris $(1, i)$ yang lama

$\left(B_{21} / B_{11}\right)=$ elemen $(2,1)$ yang lama : elemen $(1,1)$ yang lama $\mathrm{B}_{1 i}=$ hasil operasi baris (elemen baris yang baru)

sedangkan $r(A / B)$ sebagai berikut : 


$$
\left[\begin{array}{rrr}
39,48 & 42,43 & 202,64: 9,96 \\
42,43 & 75,07 & 319,84: 11,87 \\
202,64 & 319,84 & 1516,24: 56,90
\end{array}\right]
$$

langkah-langkah penyelesaian :

ẹlemen $(1,2),(1,3)$ dan $(1,4)$ di"nol"kan dengan cara : $\mathrm{K}_{2 i}=\mathrm{K}_{1 i}{ }^{\prime} \times\left(-\mathrm{K}_{21} / \mathrm{K}_{11}\right)+\mathrm{K}_{21} \cdot$ atau dapat ditulis dalam bentuk notasi $\mathrm{K}_{21}(-42,43 / 39,48)$

$\mathrm{K}_{3 i}=\mathrm{K}_{1 i^{\prime}} \times\left(-\mathrm{K}_{31} / \mathrm{K}_{11}\right)+\mathrm{K}_{3 i^{\prime}}$-atau dapat ditulis dalam bentuk notasi $K_{31}(-202,64 / 39,48)$

$\mathrm{K}_{4 i}=\mathrm{K}_{1 i} \times\left(-\mathrm{K}_{41} / \mathrm{K}_{11}\right)+\mathrm{K}_{4 i^{\prime}}$ atau dapat ditulis dalam bentuk notasi $\mathrm{K}_{41}(-9,96 / 39,48)$

sehingga didapat matrik :

$\begin{array}{ll}K_{21} & (-42,43 / 39,48) \\ K_{31} & (-202,64 / 39,48) \\ K_{41} & (-9,96 / 39,48)\end{array}\left[\begin{array}{cccc}39,48 & 0 & 0 & 0 \\ 42,43 & 29,47 & 102,06 & 1,17 \\ 202,64 & 102,06 & 476,14 & 5,78\end{array}\right]\left(B_{1}\right)$

kemudian me"nol"kan elemen $(3,1)$ dengan cara:

$B_{31}=B_{21^{\prime}} \times\left(-B_{31} / B_{21}\right)^{\prime}+B_{3 i^{\prime}}$ atau dapat ditulis dalam bentuk notasi $B_{32}(-202,64 / 42,43)$

$B_{32}(-202,64 / 42,43)\left[\begin{array}{cccc}39,48 & 0 & 0 & 0 \\ 42,43 & 29,47 & 102,06 & 1,17 \\ 0 & -38,68 & -11,28 & 0,19\end{array}\right]$


selanjutnya me"nol"kan elemen $(2,3),(2,4)$ dengan cara :

$K_{3 i}=K_{3 i} \times\left(-K_{32} / K_{22}\right)^{\prime}+K_{3 i}{ }^{\prime}$ atau dapat ditulis dalam bentuk notasi $\mathrm{K}_{32}(-102,06 / 29,47)$

$\mathrm{K}_{4 i}=\mathrm{K}_{4 i^{\circ}} \times\left(-\mathrm{K}_{42} / \mathrm{K}_{22}\right)^{\prime}+\mathrm{K}_{41^{\prime}}$ atau dapat ditulis dalam bentuk notasi $\mathrm{K}_{42}(-1,17 / 29,47)$

sehingga didapat matrik:

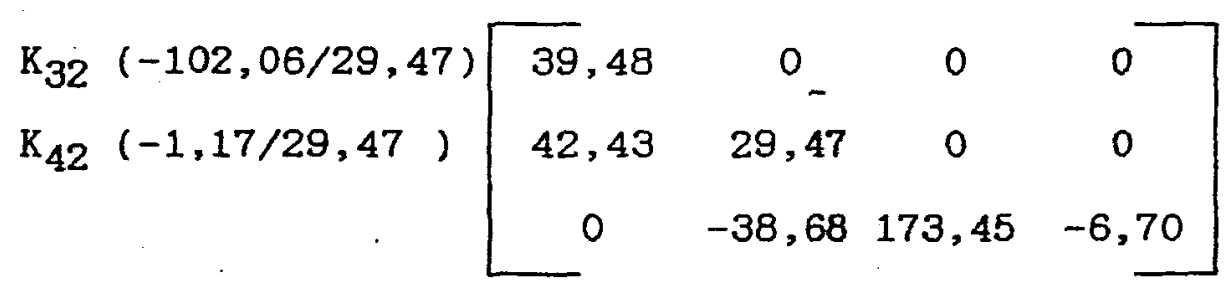

$\left(\mathrm{B}_{3}\right)$

dilanjutkan me"nol"kan elemen $(3,2),(3,4)$ dengan cara

$\mathrm{K}_{2 i}=\mathrm{K}_{3 \mathbf{i}^{-}} \times\left(\mathrm{K}_{23^{3}} / \mathrm{K}_{33}\right)^{-}+\mathrm{K}_{2 \mathbf{i}^{-}}$atau dapat ditulis dalam bentuk notasi $\mathrm{K}_{23}(38,68 / 173,45)$

$K_{4 i}=R_{4 i} \times\left(K_{43} / K_{33}\right)^{\prime}+K_{4 i^{\prime}}$ atau dapat ditulis dalam bentuk notasi $K_{43}(6,7 / 173,45)$

$\mathrm{K}_{43}(-6,7 / 173,45)\left[\begin{array}{cccc}39,48 & 0 & 0 & 0 \\ 42,43 & 29,47 & 0 & 0 \\ 0 & 0 & 173,45 & 0\end{array}\right]\left(B_{4}\right)$
$K_{23}(38,68 / 173,45)$
$K_{12}(-1,44)\left[\begin{array}{cccc}39,48 & 0 & 0 & 0 \\ 0 & 29,47 & 0 & 0 \\ 0 & 0 & 173,45 & 0\end{array}\right] \quad\left(B_{5}\right)$


karena $r(A)=r(A / B)=n$ maka persamaan tersebut mempunyai penyelesaian tunggal, sehingga :

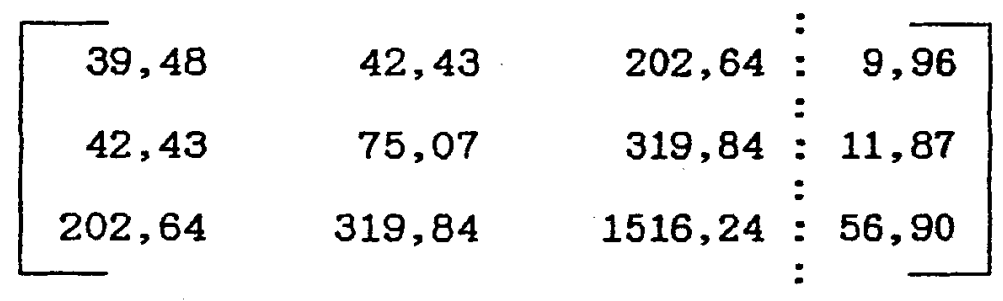

$B_{21}(-1,07)\left[\begin{array}{cccc}39,48 & 42,43 & 202,64 & 9,96 \\ 0 & 29,47 & 102,06 & 1,17 \\ 0 & 102,06 & 476,14 & 5,78\end{array}\right]$

$$
\begin{aligned}
& B_{12}(-1,44) \\
& B_{13}(-3,46)
\end{aligned}\left[\begin{array}{lcrl}
39,48 & 0 & 55,70 & 8,28 \\
0 & 29,47 & 102,06 & 1,17 \\
0 & 0 & 122,69 & 1,73
\end{array}\right]
$$

$$
\begin{aligned}
& \mathrm{B}_{13}(-0,45) \\
& \mathrm{B}_{23}(-0,83)
\end{aligned}\left[\begin{array}{lcrr}
39,48 & 0 & 55,70 & 7,49 \\
0 & 29,47 & 102,06 & -0,27 \\
0 & 0 & 122,69 & 1,73
\end{array}\right]
$$

maka didapat :

$$
\begin{aligned}
& 39,48 \quad \beta_{1}=7,49===\Rightarrow \quad \beta_{1}=0,19 \\
& 29,47 \quad B_{2}=-0,27===\Rightarrow \quad B_{2}=-0,0009 \\
& 122,64 B_{3}=1,73===\Rightarrow \quad B_{3}=0,014
\end{aligned}
$$


cek hasil perhitungan :

$\begin{aligned} 39,48(0,19)+42,43(-0,009)+202,64(0,014) & =9,96 \\ 7,5+0,38+2,84 & =9,96\end{aligned}$

( ox )

$42,43(0,19)+75,07(-0,009)+319,84(0,014)=11,87$

$$
8,06+0,68 \ldots 4,48 \quad=11,87
$$

( OK )

$202,64(0,19)+319,84(-0,009)+1516,24(0,014)$

$=56,90$

$38,5 \quad-\quad 2,88+21,23=56,90$

( OK) 


\section{EAE I I I \\ EVATUASI DATA}

\subsection{Pengumpulan / Rekaman Data}

Langkah pertama dalam mengevaluasi data ialah mengumpulkan data atau biasa disebut dengan cara rekaman data. Data-data yang kami kumpulkan ini kami ambil dari beberapa sumber yang terkait antara lain yaitu :

\section{a. Data Temperatur}

Data - data temperatur ini diambil dari Jawatan Metereologi dan Geofisika Juanda dan Jawatan Meterelogi dan Geofisika Perak I Surabaya. Data yang digunakan dalam perhitungan di sini adalah data temperatur dari Jawatan Metereologi dan Geofisika Perak I, sedangkan data dari Jawatan Metereologi dan Geofisika Juanda hanya digunakan sebagai pembanding ( tabel 1.1 \& tabel 1.2 lamp.1).

\section{b. Data Jumlah Kendaraan}

Data jumlah kendaraan meliputi data jumlah bus, Sepeda Motor, Mobil Penumpang dan Mobil Beban / Truck ( tabel 1.3 lampiran 1 ).

Data ini diambil dari Satuan Lalu Lintas Kota Surabaya (Satlantas). 


\section{c. Data Luas Lahan}

Data luas lahan meliputi data luas lahan kosong / sawah, luas industri, luas jalan dan luas bangunan ( tabel 1.4 lampiran 1 ).

Data ini diambil dari Badan Perencana Dan Pengembangan Kota Surabaya (Bappeda).

Data yang terkumpul diatas selanjutnya akan dipilih mane yang akan digunakan dan-mana yang tidak. Untuk keperluan ini digunakan batasan korelasi yang dibahas pada sub bab 3.2 .

\subsection{Koefisien Korelasi}

Langkah pertama yang dilakukan setelah data-data tersebut diatas terkumpul adalah menghitung koefisien korelasi. Koefisien korelasi digunakan untuk menentukan apakah variabel 1 dengan variabel 2 ada hubungan atau keterkaitannya. Dalam hal ini batasan yang digunakan adalah lebih besar dari 0,7 di mana jika koefisien korelasi sama atau lebih besar 0,7 maka data tersebut digunakan dan sebaliknya tidak digunakan. Dalam teori statistik batasan yang dijjinkan tidak lebih dari 1 (positif satu) dan -1 ( negatif satu ). Cara memperoleh korelasi dapat dilihat pada contoh perhitungan berikut ini, misalnya perhitungan antara temperatur $(y)$ dengan bangunan industri ( $x)$. 
TABEL 3.1 PERHITUNGAN KOEFISIEN YORELASI ANTARA TEMPERATUR DENGAN INDUSTRI

\begin{tabular}{|c|c|c|c|c|c|}
\hline \multirow{2}{*}{$\frac{\text { IRDUSTRI }}{\text { TAHUN }}$} & \multicolumn{2}{|l|}{$(\mathrm{Ha})$} & \multicolumn{3}{|c|}{ IEAPERAIUR T EaX RATA-RATA ( 'C } \\
\hline & $x$ & $x^{3}$ & Y & $y^{2}$ & $X Y$ \\
\hline 1974 & 227.0 & $51,529.0$ & 33.2 & $1,102.2$ & $7,536,4$ \\
\hline 1975 & 251.4 & $63,202.0$ & 33.0 & $1,089.0$ & $8,296.2$ \\
\hline 1976 & 314.8 & $79,099.0$ & 33.5 & $1,122.3$ & $10,545.8$ \\
\hline 1977 & 397.8 & $\{59,244.8$ & 33.8 & $1,142,4$ & $13,445.6$ \\
\hline 1978 & 467.1 & $218,182.4$ & 33.1 & $1,095.6$ & $15,461.0$ \\
\hline $1979^{\circ}$ & 476.0 & $226,576.0$ & 33.3 & $1,108.9$ & $15,950.8$ \\
\hline 1980 & 480.3 & $230,688.1$ & 33.6 & $1,129.0$ & 16.139 .1 \\
\hline 1981 & 496.7 & $25 b, 876.9$ & 33.2 & $1,102.2$ & $16,158,4$ \\
\hline 1982 & 493.1 & $248,103.6$ & 33.7 & $1,135.7$ & $16,786.0$ \\
\hline 1983 & 513.3 & $263,476.7$ & 33.9 & $1,149.2$ & $17,400.9$ \\
\hline 1984 & 523.7 & $274,261.7$ & 33.5 & $1,12.3$ & $17,544.0$ \\
\hline 1985 & 590.5 & $348,690.3$ & 34.2 & $1,159.6$ & $20,195.1$ \\
\hline 1986 & 855.3 & $732,538.1$ & 34.3 & $1,176.5$ & $29,335.8$ \\
\hline 1987 & $1,129.7$ & $1,276,222 . !$ & 34.2 & $1,169,6$ & $38,635.7$ \\
\hline 1988 & $1,258.7$ & $1,584,325.7$ & 34.4 & $1,183.4$ & $43,299.3$ \\
\hline 1989 & $1,335.7$ & $1,764,094.5$ & 34.3 & $1,176,5$ & $45,814,5$ \\
\hline JUALAH & $9,805.1$ & $7,795,111,0$ & 539.2 & $18,179.4$ & $332,444.6$ \\
\hline
\end{tabular}

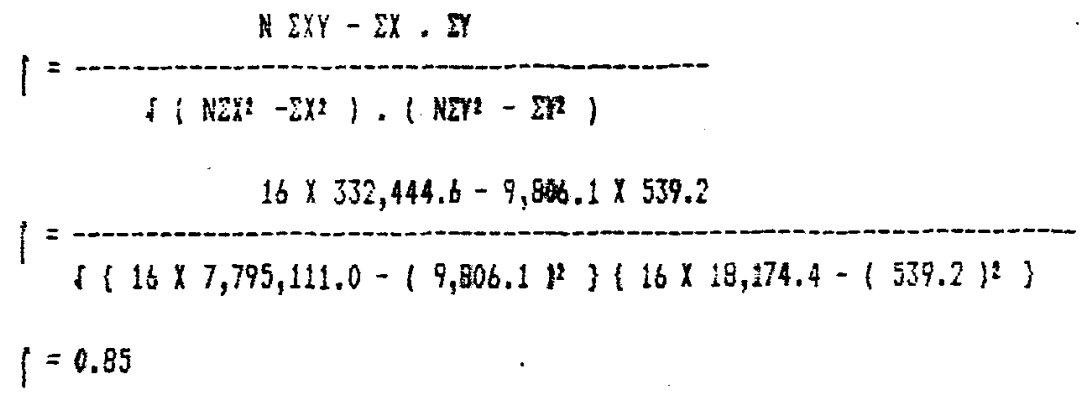


Dengan cara yang sama perhitungan seperti pada tabel 3.1 didapat hasil koefisien korelasi seperti pada tabel 3.2 .

Dari hasil perhitungan korelasi antara variabel bebas ( Temperatur) dengan variabel tidak bebas didapat hasil sebagai berikut :

Tabel. 3.2. Hasil Perhitungan Koefisien Korelasi

\begin{tabular}{|c|c|c|}
\hline : & $:$ & TEMPERATUR \\
\hline BANGUNAN & : & $c=0,85$ \\
\hline SAWAH & : & $=1,00$ \\
\hline INDUSTRI & : & $=0,85$ \\
\hline MOBIL PENUMPANG & : & $=0,87$ \\
\hline SEPEDA MOTOR & : & $=0,88$ \\
\hline TRUCK/M. BEBAN & $:$ & $=0,85$ \\
\hline BUS & : & $=0,79$ \\
\hline JALAN & : & $=0,86$ \\
\hline
\end{tabular}

( untuk jelasnya perhitungan koefisien korelasi pada tabel 3.2 dapat dilihat pada lampiran 2 ).

Dari tabel 3.2 di atas, dapat disimpulkan bahwa hubungan antara variabel bebas dan variabel tidak bebas cukup erat, sehingga variabel-variabel diatas dianggap layak dipergunakan untuk langkah selanjutnya. 


\subsection{Mode1 Interaksi}

Interaksi yang dipakai antara temperatur yang digunakan dan variabel acak yang mempunyai korelasi lebih besar dari atau sama dengan 0,7 yaitu antara lain : luas lahan pemukiman, luas daerah industri, luas lahan kosong / sawah, luas jalan dan jumlah kendaraan bermotor meliputi : mobil penumpang, truk dan bus ) dapat dibuat suatu model interaksi yang ditulis sebagai berikut :

$$
T=Y+\beta_{1} x_{1}+\beta_{2} x_{2}+\ldots . .+\beta_{8} x_{8}
$$

di mana :

$\mathrm{T}$ = Temperatur akhir keadaan kota Surabaya akibat faktorfaktor tersebut di atas.

$Y$ = Temperatur dasar kota Surabaya ( yang diambil dari data-data temperatur tiap tahun ) $=33,7^{\circ} \mathrm{C}$.

$\beta_{n}=$ suatu koefisien dari faktor $x_{n}$.

$x_{1}=$ luas jalan per luas kota $(\% / 00)$.

$x_{2}=$ luas bangunan per luas kota $(\% / 0)$.

$x_{3}=$ luas lahan industri per luas kota ( $\%$ ).

$\mathrm{x}_{4}=$ sepeda motor per 10.000 sepeda motor.

$\mathrm{x}_{5}=$ mobil per 10.000 mobil.

$x_{6}=$ truck per 1.000 truck.

$\mathbf{x}_{7}=$ bus per 100 bus.

$x_{8}=$ sawah per luas kota $(\% / 0)$. 
Dari persamaan ( 2.7 ) halaman 11, perhitungan dapat dijabarkan sebagal berikut :

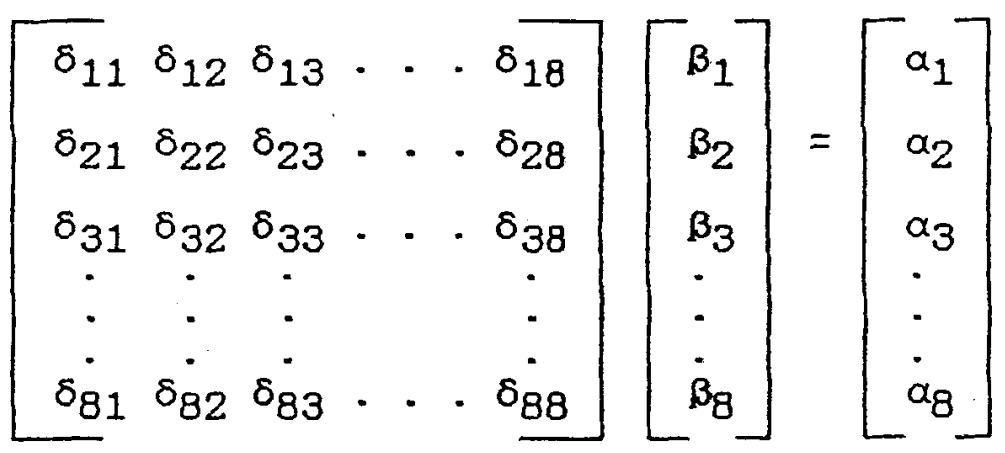

dimana :

$$
\begin{aligned}
& \delta_{11}=\left(x_{1 i}-\bar{x}_{1}\right)^{2} \\
& \delta_{22}=\left(x_{21}-\bar{x}_{2}\right)^{2} \\
& \delta_{88}=\left(x_{81}-\bar{x}_{8}\right)^{2} ; \\
& \delta_{12}=\delta_{21}=\left(x_{1 i}-\bar{x}_{1}\right)\left(x_{2 i}-\bar{x}_{2}\right) \\
& \delta_{13}=\delta_{31}=\left(x_{1 i}-\bar{x}_{1}\right)\left(x_{3 i}-\bar{x}_{3}\right) \\
& \delta_{78}=\delta_{87}=\left(x_{7 i}-\bar{x}_{7}\right)\left(x_{81}-\bar{x}_{8}\right) \text { dan } \\
& \alpha_{1}=\left(x_{1 i}-\bar{x}_{1}\right)\left(y_{i}-\bar{y}\right) \\
& a_{2}=\left(x_{2 i}-\bar{x}_{2}\right)\left(y_{i}-\bar{y}\right) \\
& a_{B}=\left(x_{81}-\bar{x}_{8}\right)\left(y_{1}-\bar{y}\right)
\end{aligned}
$$


Dari lampiran 5, kita dapatkan bentuk persamaan sesungguhnya sebagai berikut :

$\Leftrightarrow 39.48 \beta_{1}+42.43 \beta_{2}+202.64 \beta_{3}+184.71 \beta_{4}+49.74 \beta_{5}$

$+303.37 \beta_{6}+121.26 \beta_{7}-66.67 \beta_{8}=9.96$

$\Leftrightarrow 42.43 \beta_{1}+75.07 \beta_{2}+319.84 \beta_{3}+303.87 \beta_{4}+66.98 \beta_{5}$ $+364.09 \beta_{6}+148.31 \beta_{7}-111.35 \beta_{8}=11.87$

$\Leftrightarrow 202.64 \beta_{1}+319.84 \beta_{2}+1516.24 \beta_{3}+952.63 \beta_{4}+$ $300.16 \beta_{5}+1653.4 \beta_{6}+677.81 \beta_{7}-491.93 \beta_{8}=56.9$

$\Leftrightarrow 184.71 \beta_{1}+203.87 \beta_{2}+952.63 \beta_{3}+917.87 \beta_{4}$ $+243.93 \beta_{5}+1502.62 \beta_{6}+603.07 \beta_{7}-317.8 \beta_{8}=46.9$

$\Leftrightarrow 49.74 \beta_{1}+66.98 \beta_{2}+300.16 \beta_{3}+243.93 \beta_{4}+70.69 \beta_{5}$ $+411.73 \beta_{6}+164.7 \beta_{7}-102.03 \beta_{8}=13.37$

$\Leftrightarrow 303.37 \beta_{1}+364.09 \beta_{2}+1653.4 \beta_{3}+1502.62 \beta_{4}+$ $411.73 \beta_{5}+2501.87 \beta_{6}+1010.95 \beta_{7}-560.11 \beta_{8}=77.4$

$\Leftrightarrow 121.26 \beta_{1}+148.31 \beta_{2}+677.81 \beta_{3}+603.07 \beta_{4}+164.7$ $\beta_{5}+1010.95 \beta_{6}+422.29 \beta_{7}-228.34 \beta_{8}=29.77$

$\Leftrightarrow-66.67 \beta_{1}-111.35 \beta_{2}-1491.94 \beta_{3}-317.8 \beta_{4}-102.03$ $\beta_{5}-560.11 \beta_{6}-228.34 \beta_{7}+167.29 \beta_{8}=-18.58$ 
atau dapat dituliskan dalam bentuk matriknya :

$\left[\begin{array}{rrrrrrrr}39.49 & 12.43 & 202.64 & 184.71 & 49.74 & 303.37 & 121.26 & -66.75 \\ 12.43 & 75.07 & 319.84 & 203.87 & 66.98 & 364.09 & 148.31 & -111.35 \\ 202.64 & 319.84 & 1516.24 & 952.63 & 300.16 & 1653.4 & 677.81 & -491.93 \\ 184.71 & 203.87 & 952.63 & 917.87 & 243.93 & 1502.62 & 603.07 & -317.8 \\ 19.74 & 66.98 & 300.16 & 243.93 & 70.69 & 411.73 & 164.7 & -102.03 \\ 303.37 & 364.09 & 1653.4 & 1502.62 & 411.73 & 2501.78 & 1010.95 & -560.11 \\ 121.26 & 148.31 & 677.81 & 603.07 & 164.7 & 1010.95 & 422.29 & -228.34 \\ -66.75 & -111.35 & -491.94 & -317.8 & -102.03 & -560.11 & -228.34 & 167.29\end{array}\right] \quad\left[\begin{array}{l}81 \\ 82 \\ 83 \\ 84 \\ 85 \\ 86 \\ 87 \\ 88\end{array}\right]==\left[\begin{array}{r}9.96 \\ 11.87 \\ 56.9 \\ 46.9 \\ 13.37 \\ 77.4 \\ 29.77 \\ -18.58\end{array}\right]$.

Dengan dilakukan perhitungan secara sistem persamaan linier ( dibahas pada bab 2 hal. 15 ) maka didapat semua variabel atau faktor-faktor yang terkait, sehingga model temperatur didapatkan suatu rumusan :

$$
\begin{aligned}
Y= & 33.7-0,18 x_{1}-3,52 x_{2}-0,32 x_{3}-0,02 x_{4}+0,44 \\
& x_{5}+0,03 x_{6}-0,06 x_{7}-3.33 x_{8}
\end{aligned}
$$

( Untuk lebih jelasnya perhitungan dapat dilihat pada lampiran 3 ).

Dari persamaan diatas dilakukan " cek hasil " temperatur kota Surabaya sebagai berikut :

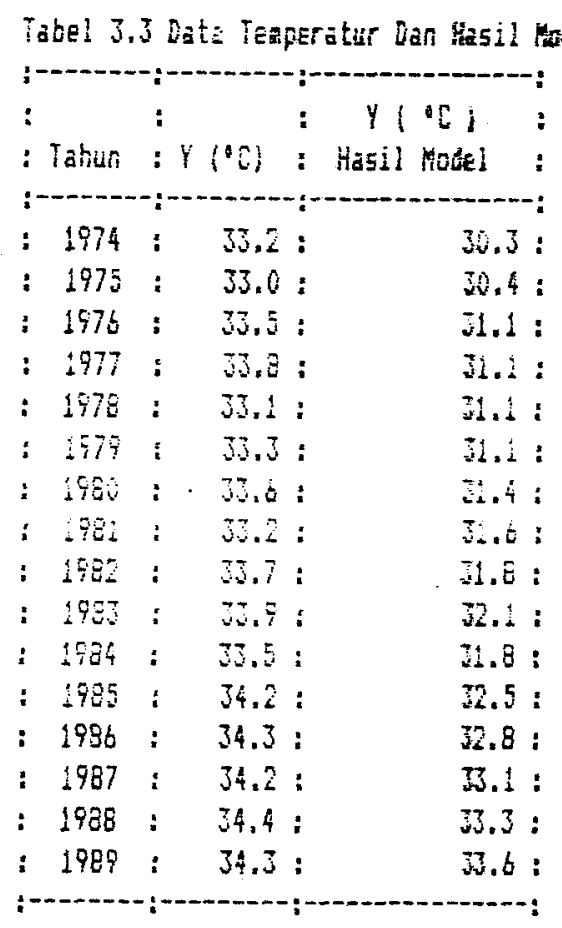


Dari data cek hasil di atas, maka data tersebut dapat diolah kembali untuk mendapatkan data pendekatan yang mendekati data sesungguhnya. Dengan melakukan "trial and error " make tiap data dari "cek hasil " ditambahkan suatu nilai $\mathbb{A}=0.8$, sehingga didapat data cek hasil yang baru sebagal berikut :

\begin{tabular}{|c|c|c|c|c|}
\hline \multicolumn{5}{|c|}{ 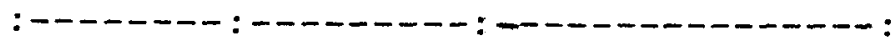 } \\
\hline$:$ & $:$ & & : & $\mathrm{Y}\left({ }^{\circ} \mathrm{C}\right)$ \\
\hline : & : & & : & Hasil \\
\hline : Tahun & : Y & $\left({ }^{\circ} \mathrm{C}\right)$ & : & Pendekatan \\
\hline 1974 & $:$ & 33.2 & : & 31.1 \\
\hline 1975 & : & 33.0 & : & 31.2 \\
\hline 1976 & : & 33.5 & : & 31.9 \\
\hline 1977 & : & 33.8 & : & 31.9 \\
\hline 1978 & : & 33.1 & : & 31.9 \\
\hline 1979 & : & 33.3 & $:$ & 31.9 \\
\hline 1980 & $:$ & 33.6 & : & 32.2 \\
\hline 1981 & : & 33.2 & : & 32.4 \\
\hline 1982 & $:$ & 33.7 & : & 32.6 \\
\hline 1983 & $:$ & 33.9 & : & 32.9 \\
\hline 1884 & : & 33.5 & : & 32.6 \\
\hline 1985 & : & 34.2 & : & 33.3 \\
\hline 1986 & $:$ & 34.3 & : & 33.6 \\
\hline 1987 & $:$ & 34.2 & : & 33.9 \\
\hline 1988 & : & 34.4 & : & 34.1 \\
\hline 1889 & : & 34.3 & : & 34.4 \\
\hline
\end{tabular}


Dari tabel 3.4 dapat dibentuk suatu grafik sbb :

Grafik 1.1 : Temperatur Surabaya \& Hasil Pendekatan

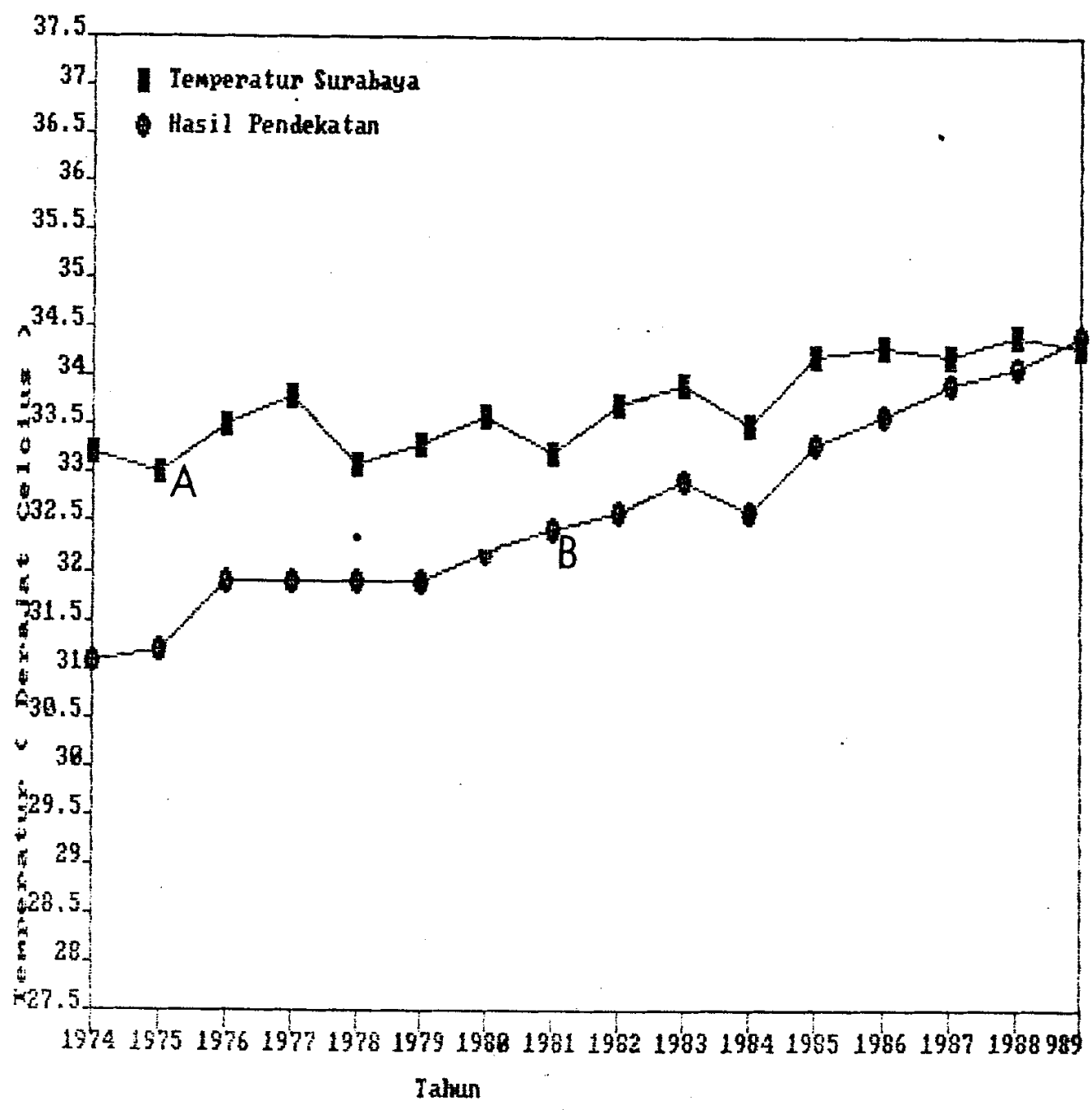

di mana :

$A=$ grafik temperatur kota sesungguhnya

$B=$ grafik hasil pendekatan 


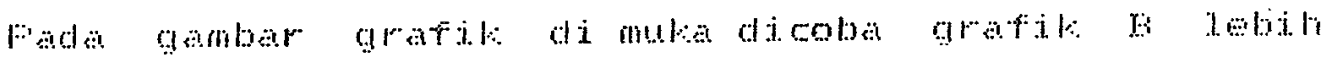

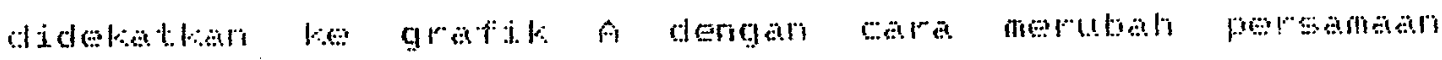
sebagni berikut "

$$
\begin{aligned}
y & =33,7-0,18 x_{1}-3,49 x_{2}-0,32 x_{3}-0,02 x_{4}-0,44 x_{5} \\
& -0,03 x_{6}-0,06 x_{7}-3,25 x_{8}+(\Delta=0,8)
\end{aligned}
$$

dickpat. hasit sebagai beritot:

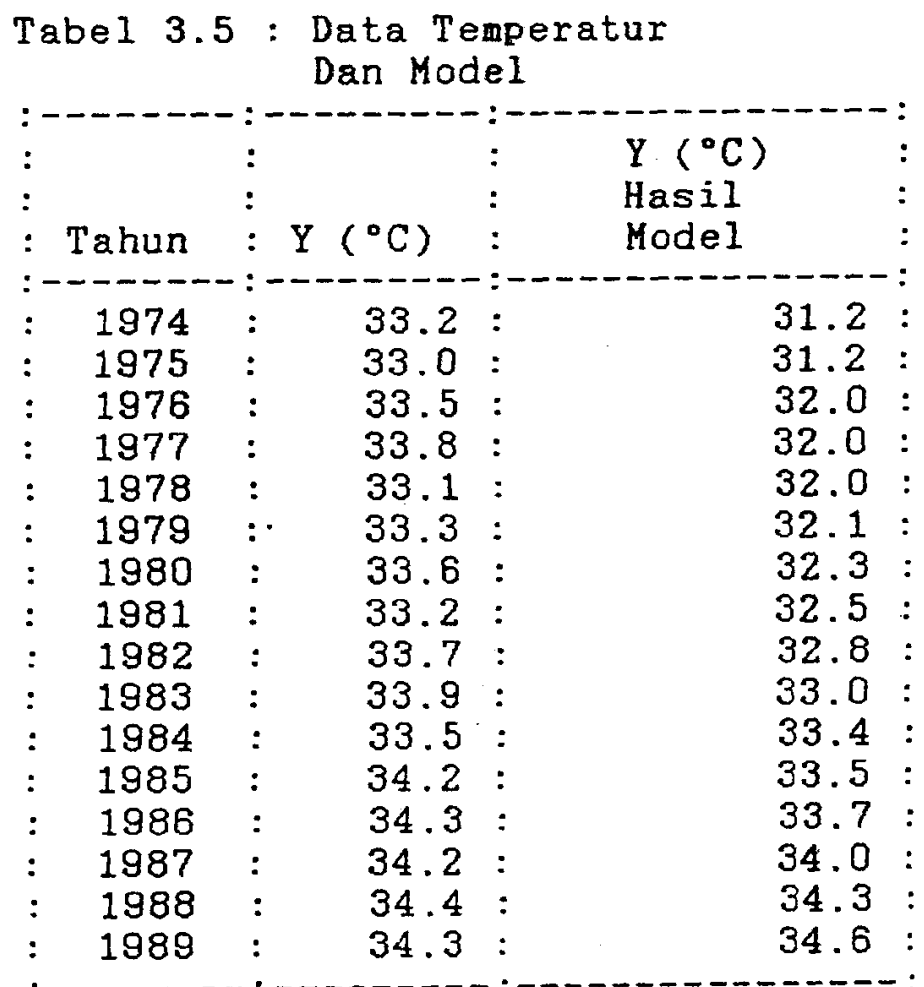


Dari tabel 3.5 dapat dibentuk suatu grafik sbb :

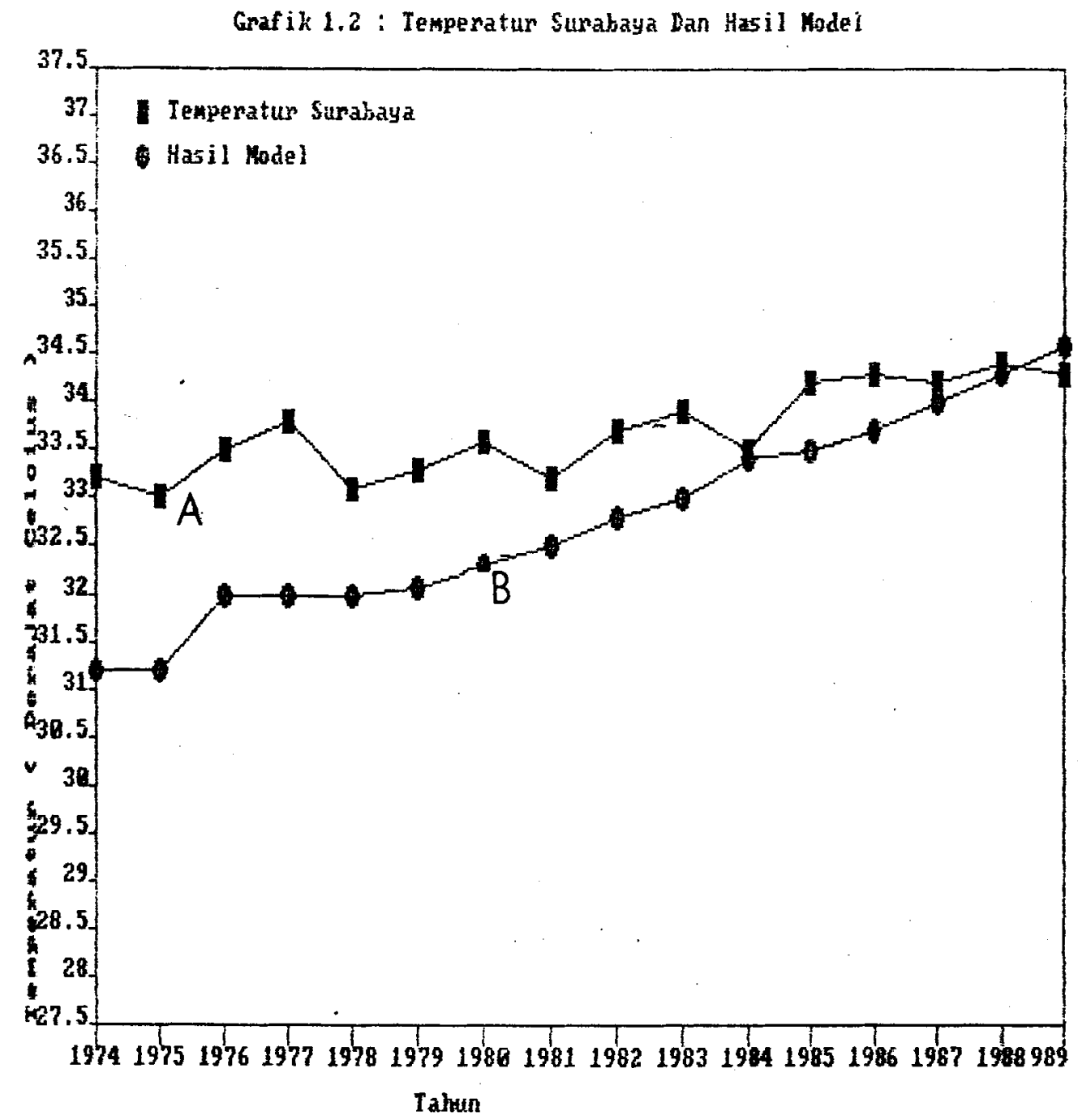

di mana :
$A=$ grafik temperatur kota sesungguhnya
$B=$ grafik hasil model 


\section{EAE IV \\ KESIMPUIMAN DAN SARAN}

Berdasarkan data-data yang telah didapatkan dan yang diolah dapat disimpulkan :

1. Bahwa berdasarkan data temperatur maupun hasil model sama-sama menunjukkan peningkatan temperatur.

2. Bahwa dengan cara Multiple Linier Regression yang diterapkan untuk mendapatkan korelasi antara kenaikkan temperatur dan variabel-variabel yang mempengaruhi perubahan temperatur tersebut tidak didapat hasil seperti yang diharapkan dengan adanya variabel yang bernilai negatif sehingga variabel-variabel yang harapkan tidak mendukung teori anggapan semula. Dari teori Multiple Linier Regression ternyata bila digunakan untuk 3 persamaan diperoleh hasil yang tepat dan bila digunakan untuk banyak persamaan ( misal : 8 persamaan ) tidak didapatkan hasil yang tepat melainkan perlu ditambah dengan cara pendekatanpendekatan agar diperoleh hasil perhitungan yang tepat.

3. Dalam hal ini ( no. 2) dapat diperlihatkan dari grafik-grafik yang menunjukkan adanya perbedaan yang menyolok dari tiap-tiap variabel sehingga diperlukan skala yang berbeda - beda pada setiap variabel tersebut yang menunjukkan kurang eratnya interaksi variabel-variabel bebas dengan temperatur (lamp. 1.6 ). 
4. Didalam model yang telah dibuat, menghasilkan perubahan temperatur yang berdasarkan hanya kepada faktor-faktor yang ditinjau saja sedangkan perubahan temperatur tidak cukup hanya karena ke-8 faktor tersebut di atas sehingga perlu ditambahkan beberapa faktor yang akan lebih melengkapi pengaruhnya terhadap perubahan temperatur.

SARAN - SARAN :

1. Dalam penggunaan tanah - tanah kosong hendaknya diperhitungkan kegunaannya dan ditata secara baik. Dalam arti setiap penggunaan tanah kosong baik untuk perumahan atau pembangunan gedung hendaknya diimbangi dengan memperbanyak taman dan jalur hijau sebagai hutan kota yang berfungsi selain untuk keindahan kota juga sebagai paru-paru kota.

2. Mulai diperhatikannya pembangunan kota yang berdampak positif dalam arti tidak merusak lingkungan dan kelestarian, tentunya diperlukan suatu penataan kota yang benar - benar terencana dan matang. Semua ini tidak akan berjalan dengan baik tanpa adanya dukungan dari semua pihak baik masyarakat maupun pemerintah. 
1. Ang, AHS, and Tang, WH, Probability concepts in Engineering Planning and Design Volume $I$, Basic Principle, John Wileyand Sons, 1984

2. Poerwadarminto, WJS, Kamus Umum Bahasa Indonesia, Balai Pustaka, Jakarta, 1984

3. Nasir, Moh, Metode Penelitian, Ghalia Indonesia, Jakarta, 1983

4. Perpustakaan Universitas Kristen Petra, Pedoman Umum Penulisan Laporan / Tugas Akhir/Thesis, Surabaya, 1990 


\section{BERITA ACARA \\ PEMBIMIBINGAN SKRIPSI}

\begin{tabular}{|c|c|c|}
\hline $\begin{array}{l}\text { Nep Mahasiswa } \\
\text { 1. } . .13285504 \\
\text { 2. } . .13287528\end{array}$ & $\begin{array}{l}\text { Nama mahasiswa } \\
\text { Srie...Winoho.Mudjanarko....... } \\
\text { M...Bagus..H.i.j.ay.a.................... }\end{array}$ & 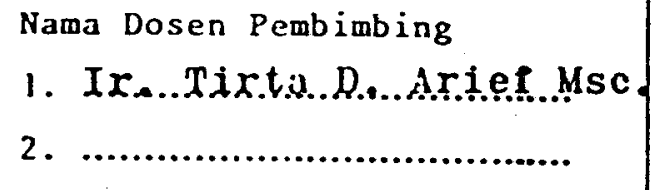 \\
\hline \multicolumn{3}{|c|}{ 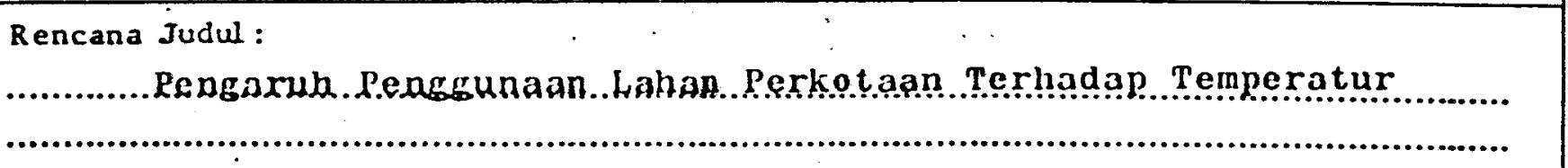 } \\
\hline
\end{tabular}

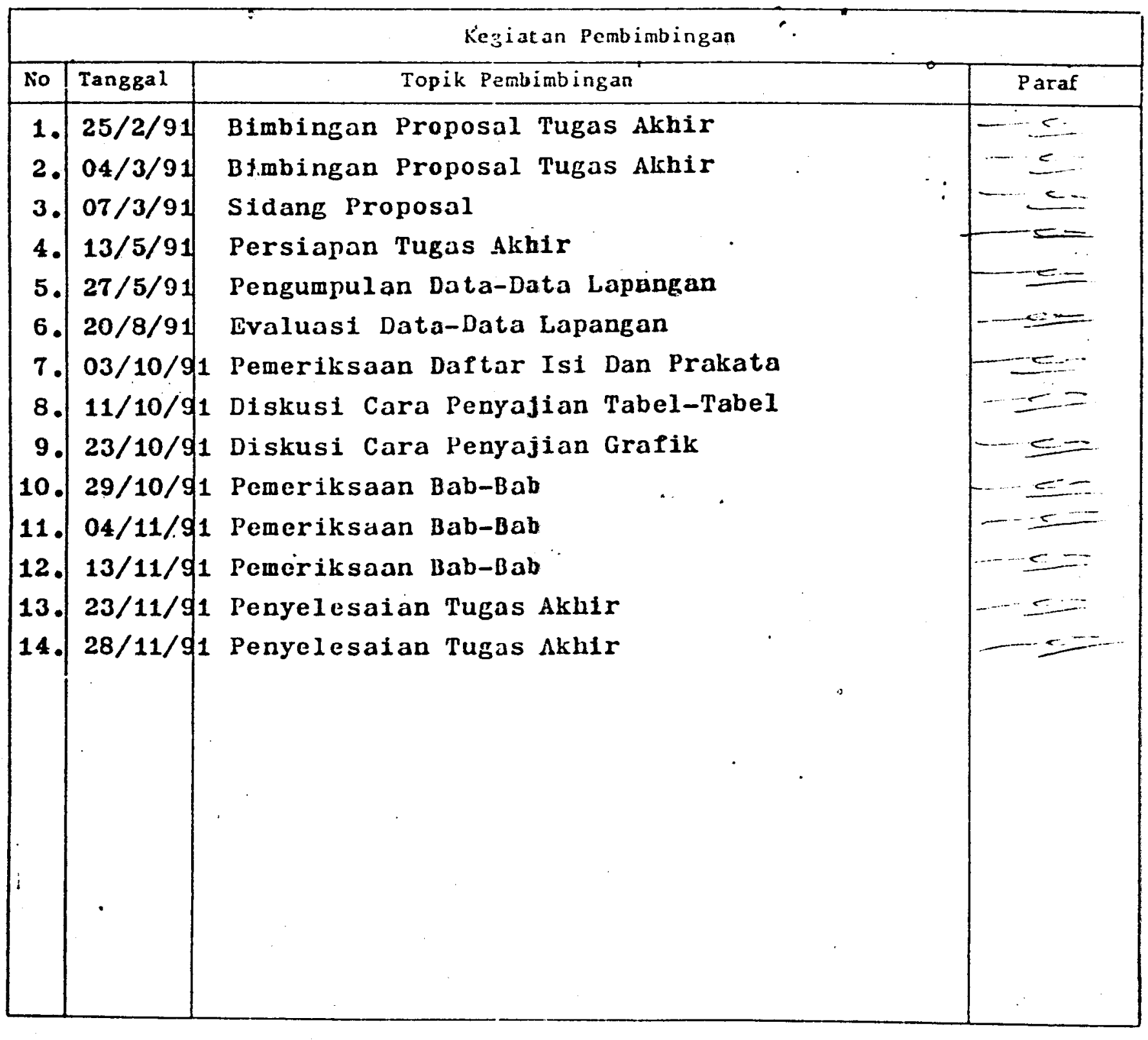


TAEEL 1.1 : DATA TEMFEFATUF DAN KELEMEAEAN

STASIUN METEFEOLOGI PERAK I

( MEWAKILI IKLIM KOTA SURABAYA)

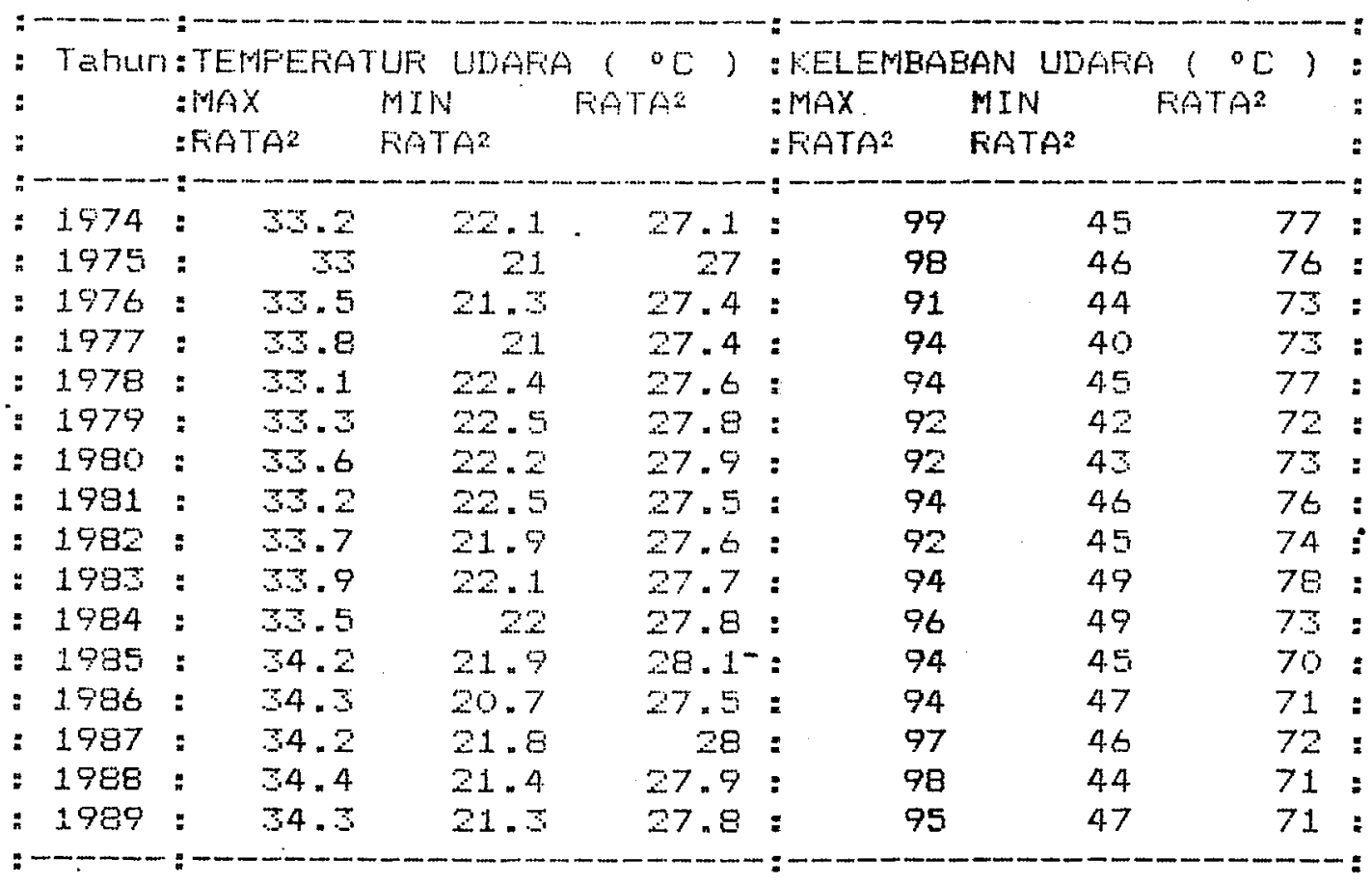

TAEEL $1.2:$ DATA TEMFEFATUF DAN KELEMBABAN

STASIUN METEREOLOGI JUANDA

( MEWAKILI IKLIM FEDESAAN)

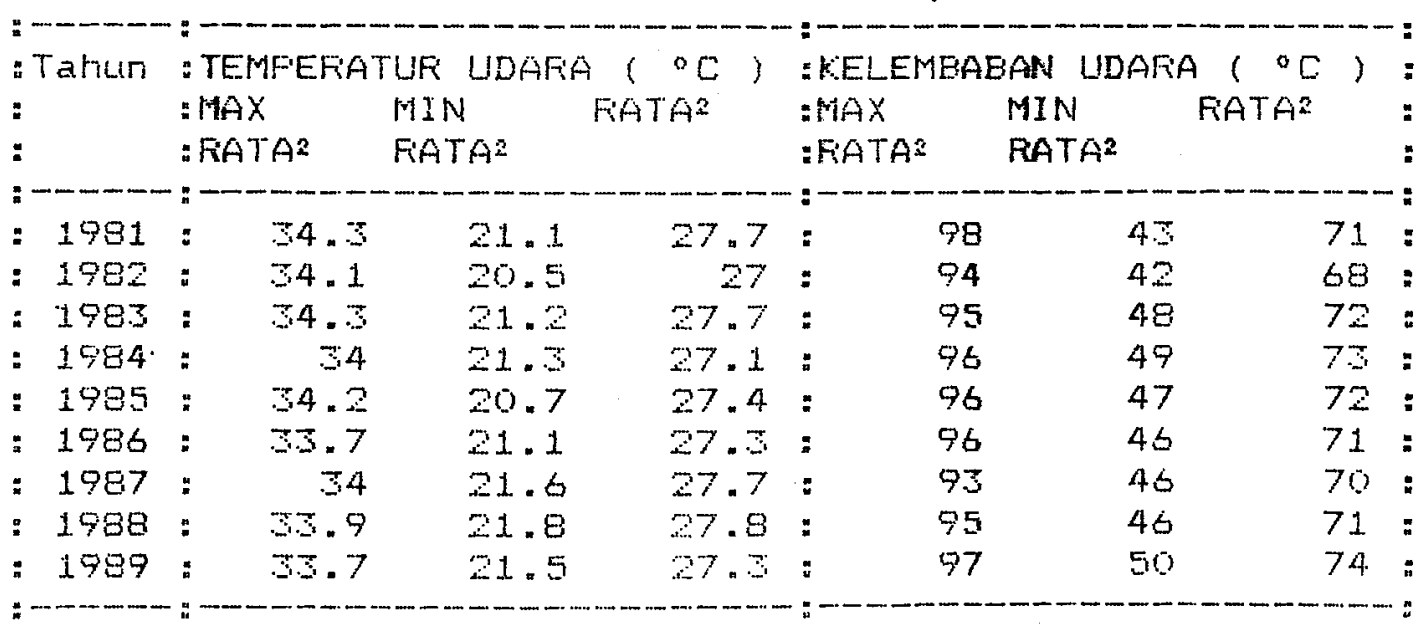


TABEL 1.3 : DATA JUMLAH KENDARAAN

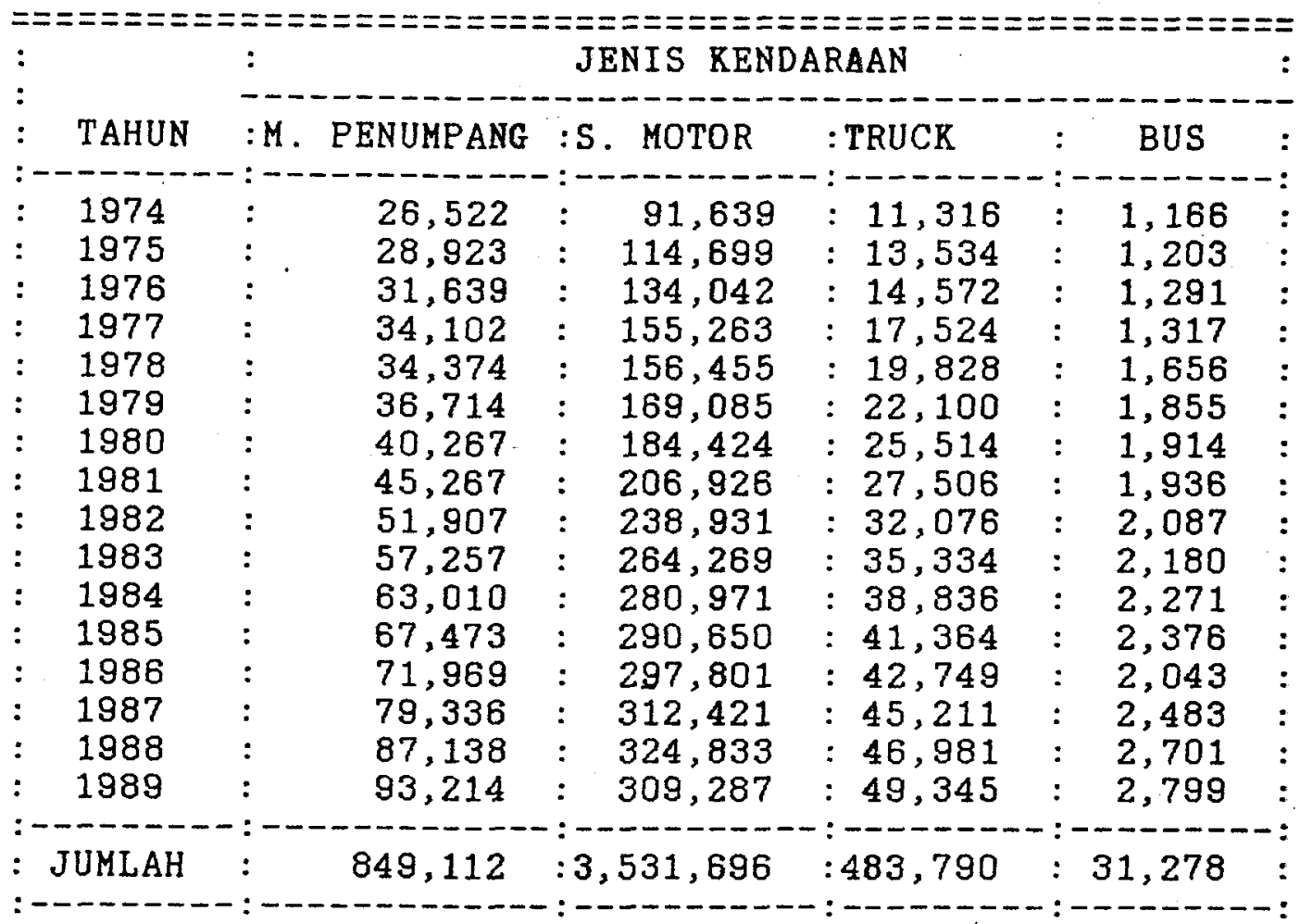

Tabel 1.4 : Data-Data Luas Lahan Kata Surabaya

\begin{tabular}{|c|c|c|c|c|c|c|c|c|}
\hline : Tahun & & h kosone & : Bangunan & $\begin{array}{l}: I \\
: \\
:(\end{array}$ & dustri & $\begin{array}{l}: \mathrm{J} \\
: \\
:(\end{array}$ & $\mathrm{Ha})$ & $\begin{array}{l}: \text { Jumlah } \\
:(\mathrm{Ha})\end{array}$ \\
\hline 1974 & : & 16031 & 9676.4 & : & 227 & $:$ & 208.7 & 2614 \\
\hline 1975 & : & 16471 & 9714.8 & : & 251.4 & : & 248.51 & $: 26685.71$ \\
\hline 1976 & : & 16809 & 9851.4 & : & 314.8 & : & 274.3 & : 27249.5 \\
\hline 1977 & : & 17617 & 10052 & : & 397.8 & : & 283.7 & 28350.5 \\
\hline 1978 & : & 17716.4 & 10573.6 & : & 467.1 & : & 287.2 & 29044.3 \\
\hline 1979 & : & 17933.7 & 10786.4 & : & 476 & : & 291 & 29487.1 \\
\hline 1980 & : & 18087.5 & 11147.5 & : & 480.3 & : & 330.4 & 30045.7 \\
\hline 1981 & : & 18165 & 11321.8 & : & 486.7 & : & 338.7 & 30312.2 \\
\hline 1982 & : & 18533.5 & 11513.2 & : & 498.1 & : & 346.2 & 30891 \\
\hline 1983 & : & 18758.2 & 11764.8 & : & 513.3 & : & 363.5 & 31399.8 \\
\hline 1984 & : & 18801.4 & 11896.4 & : & 523.7 & : & 375.1 & 31596.6 \\
\hline 1985 & : & 18708.7 & 12276.7 & $:$ & 590.5 & $:$ & 407.5 & 31983.4 \\
\hline 1986 & : & 18244.6 & 12573.6 & : & 855.3 & $:$ & 423.2 & 32096.7 \\
\hline 1987 & : & 17502.8 & 13147.3 & $:$ & 1129.7 & $:$ & 426.4 & 32206.2 \\
\hline 1988 & : & 12215.8 & 13473.6 & : & 1258.7 & : & 430 & 27378.1 \\
\hline & : & & 14268 & & 1335.7 & • & 430.3 & 32649.7 \\
\hline
\end{tabular}




\section{5 : GRAFIK TEMFERATUR BULANAN MAXIMUM FENGAMATAN STASIUN PERAK DAN PENGAMATAN STASIUN JUANDA 1981 - 1989}

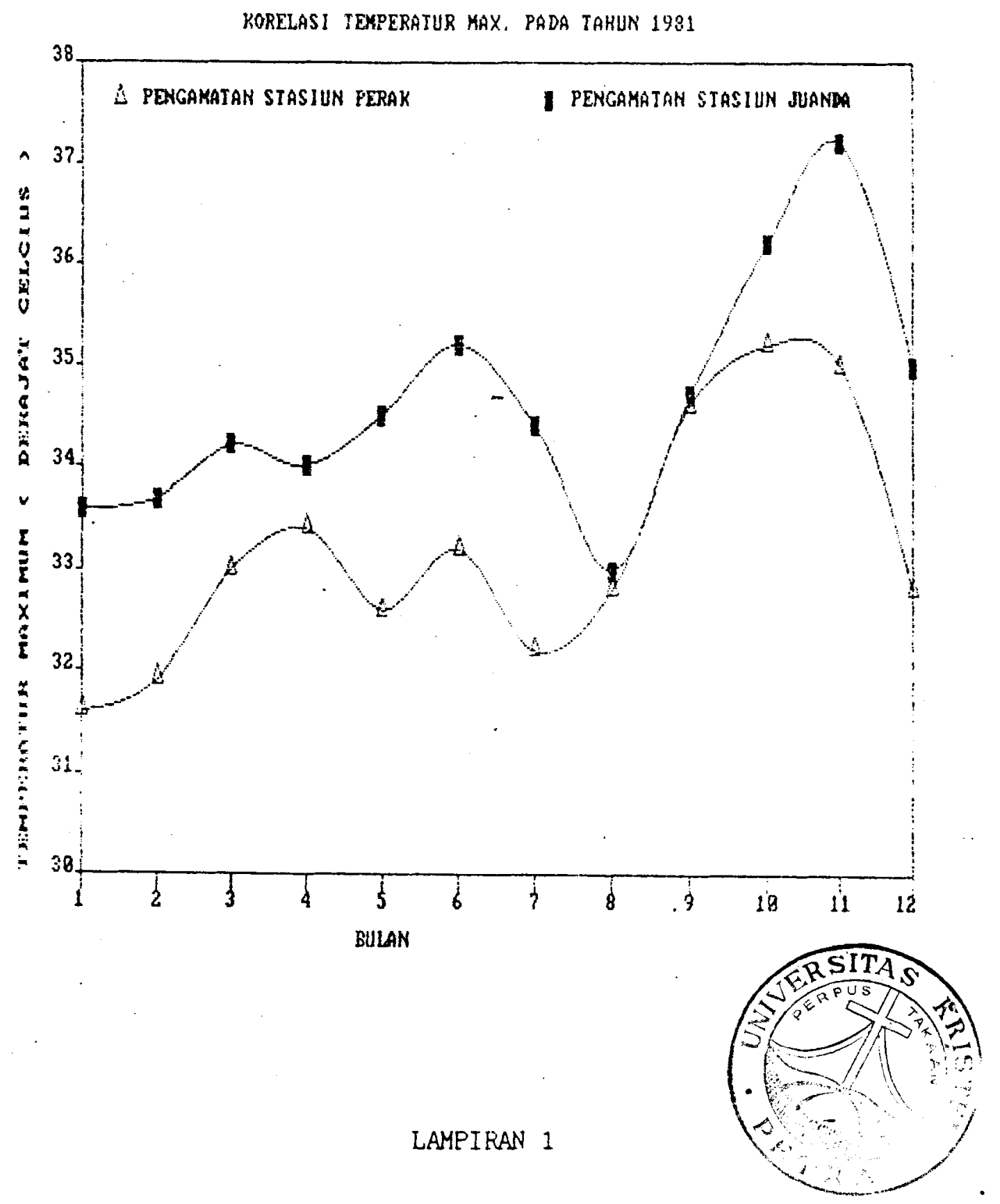


1.5 : GRAFIK TEMPERATUR BULANAN MAXIMUM PENGAMATAN STASIUN PERAK DAN PENGAMATAN STASIUN JUANDA 1981 - 1989

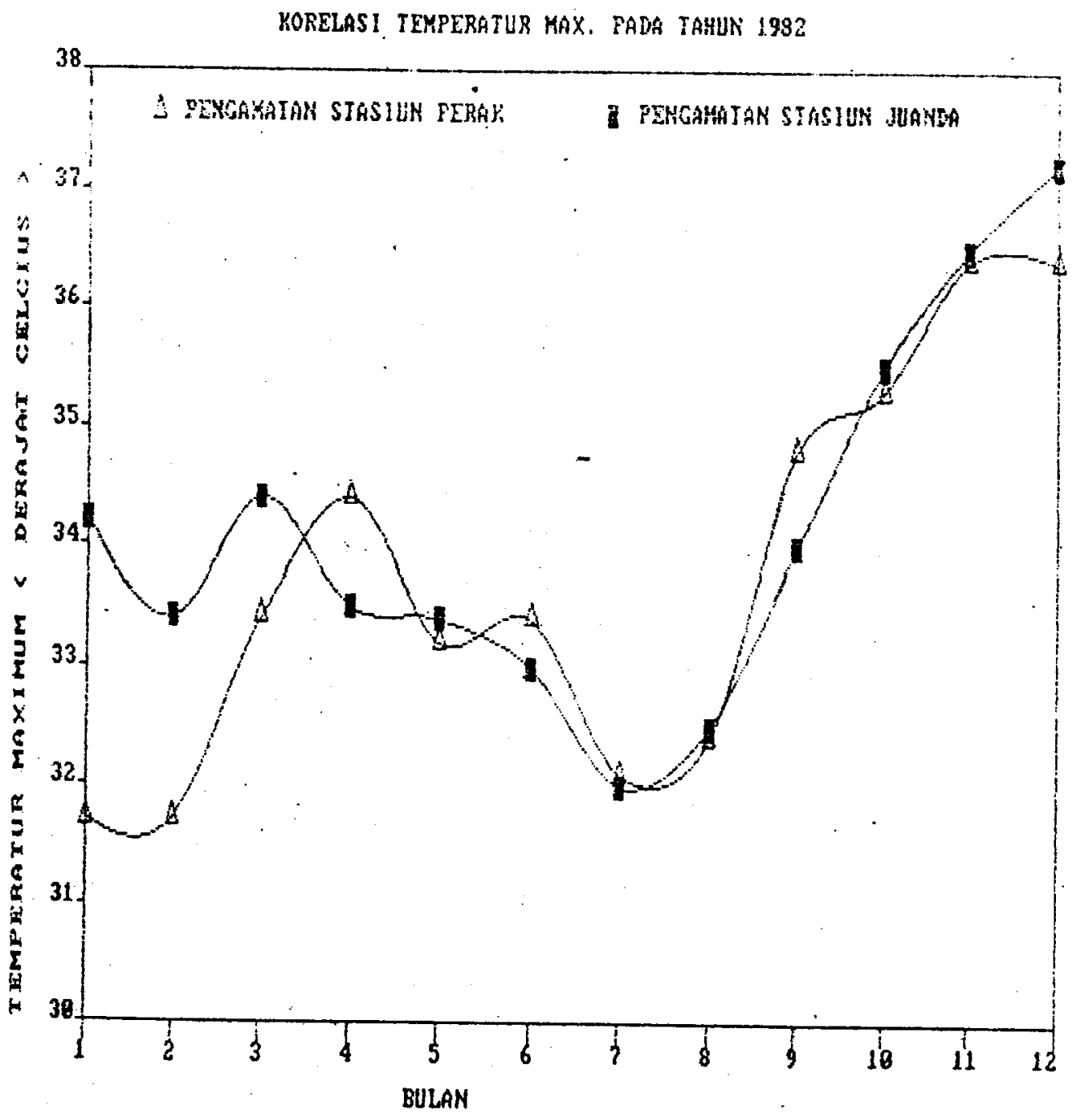

LAMPIRAN 1 
1.5 : GRAFIK TEMFERATUR EULANAN MAXIMUM PENGAMATAN STASIUN FERAK DAN PENGAMATAN STASIUN JUANDA 1981 - 1989

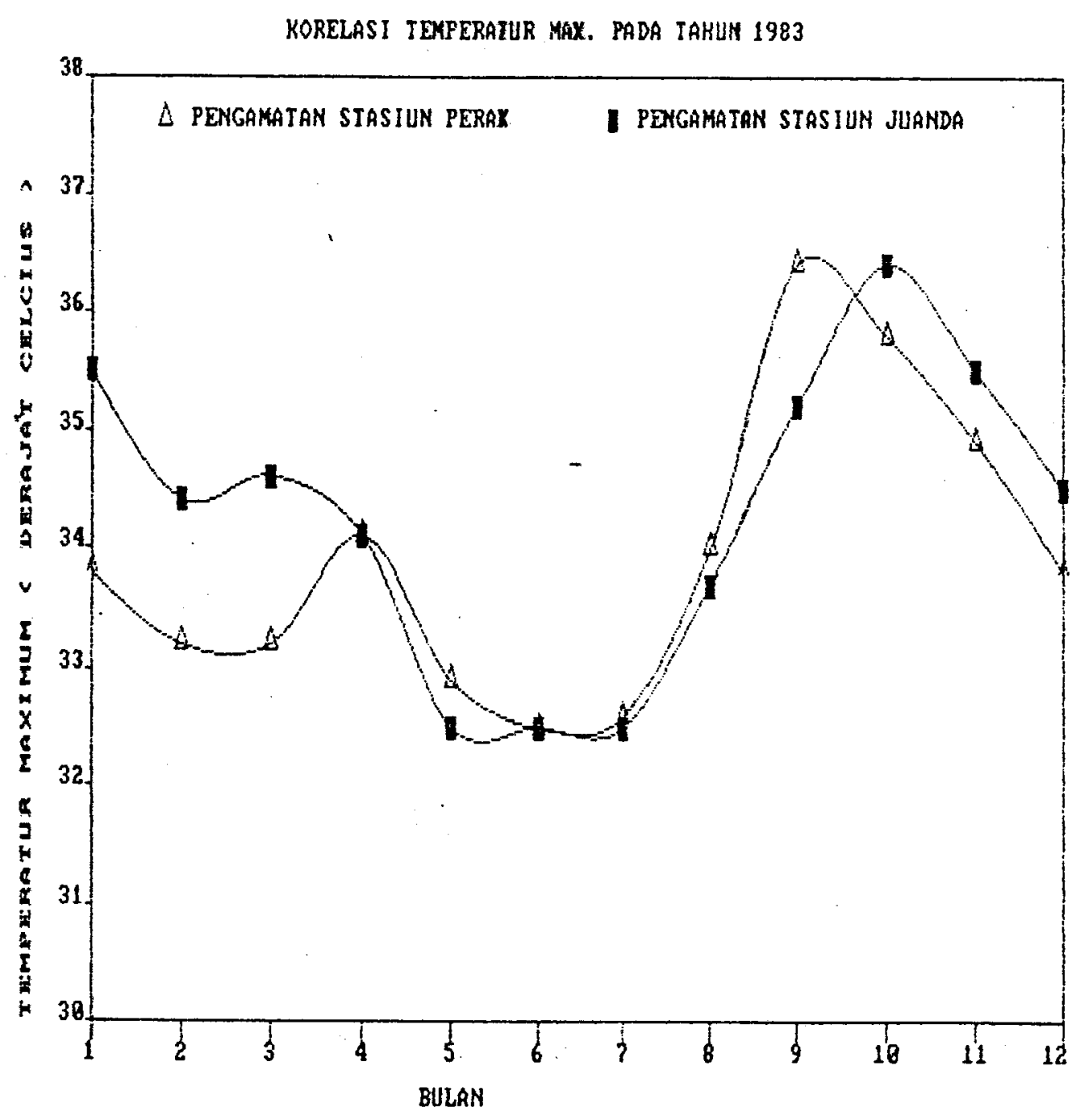

LAMPIRAN 1 
1.5 : GRAFIK TEMPERATUR BULANAN MAXIMUM PENGAMATAN STASIUN PERAK DAN PENGAMATAN STASIUN JUANDA $198^{\circ} 1$ - 1989

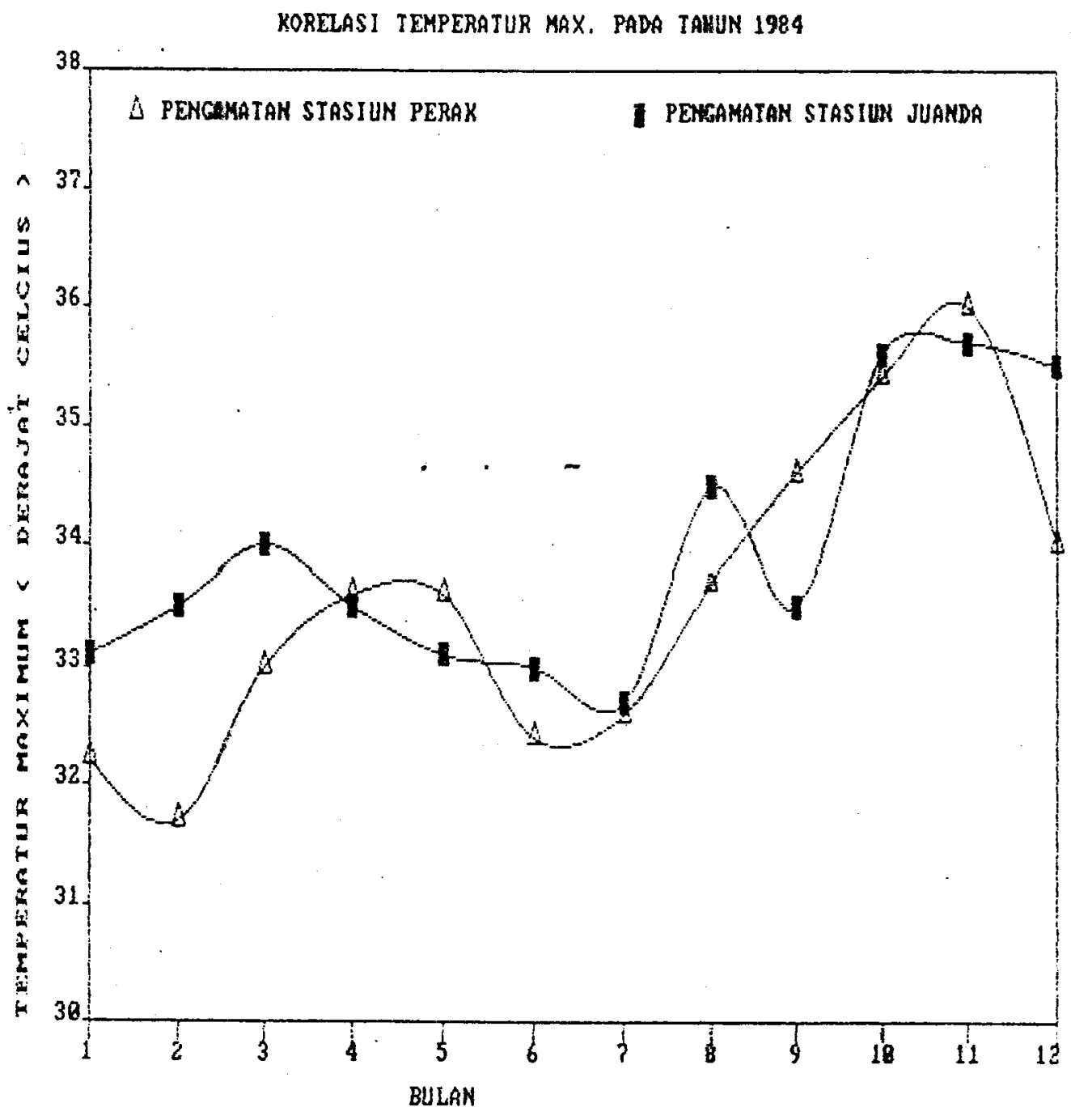

LAMPIRAN 1 
1.5 : GRAFIK TEMPERATUF EULANAN MAXIMUM FENGAMATAN STASIUN PERAK DAN PENGAMATAN STASIUN JUANDA 1981 - 1989

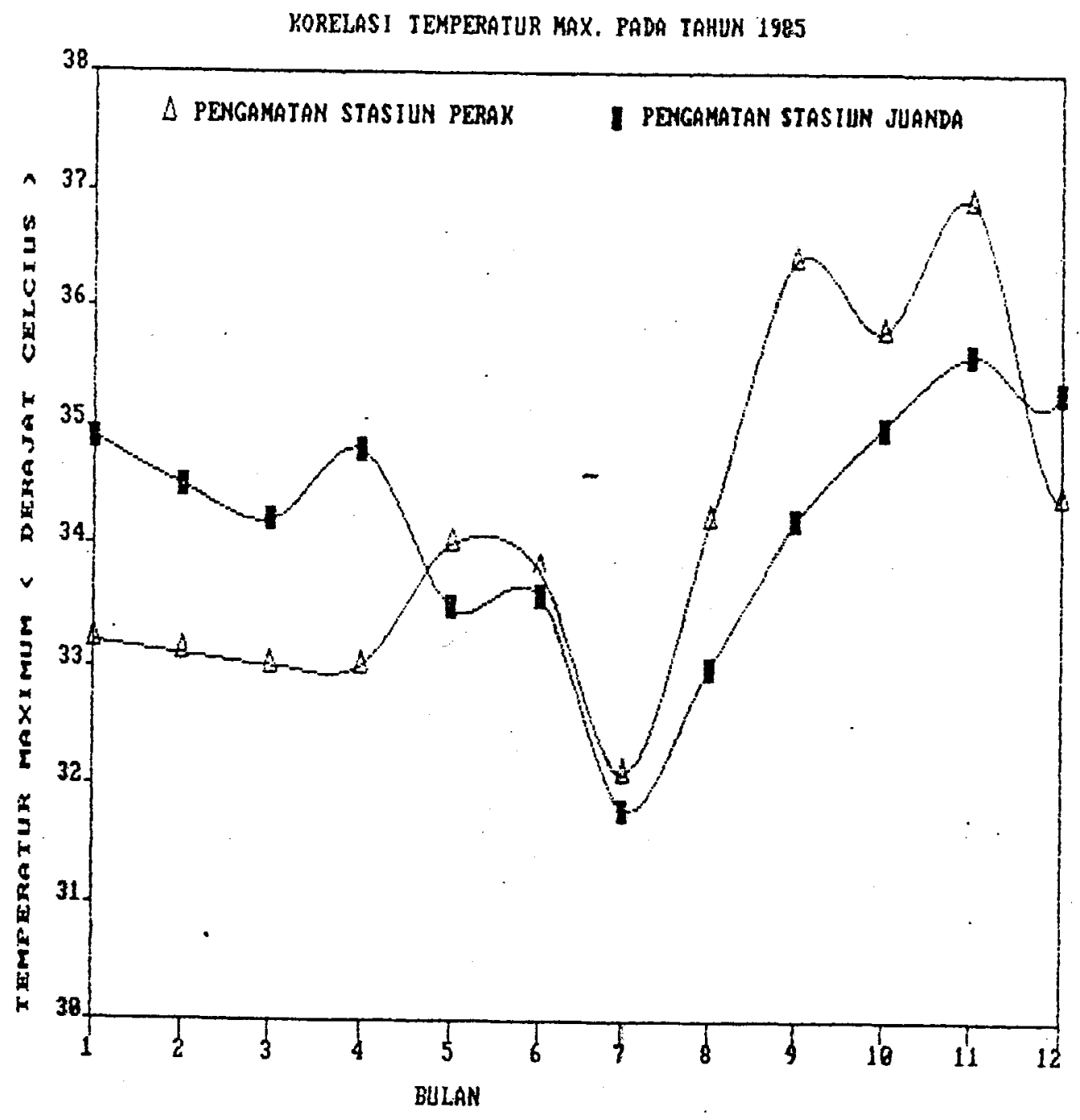

LAMPIRAN 1 


\section{5 : GRAFIK TEMPERATUR BULANAN MAXIMUM PENGAMATAN STASIUN}

PERAK DAN PENGAHATAN STASIUN JUANDA 1981 - 1989

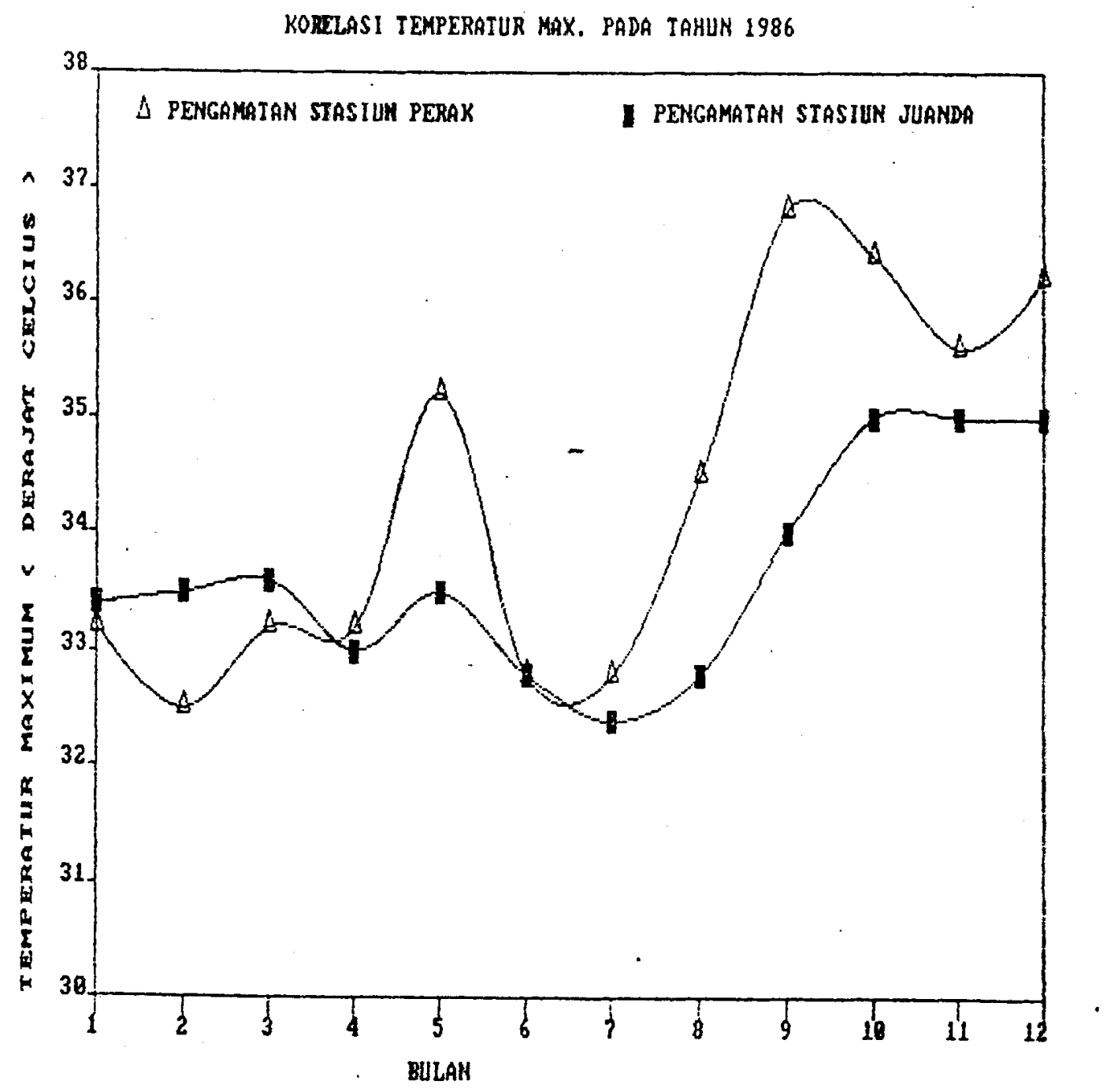

LAMPIRAN 1 
1.5 : GRAFIK TEMFERATUR BULANAN MAXIMUM PENGAMATAN STASIUN PERAK DAN PENGAMATAN STASIUN JUANDA 1981 - 1989

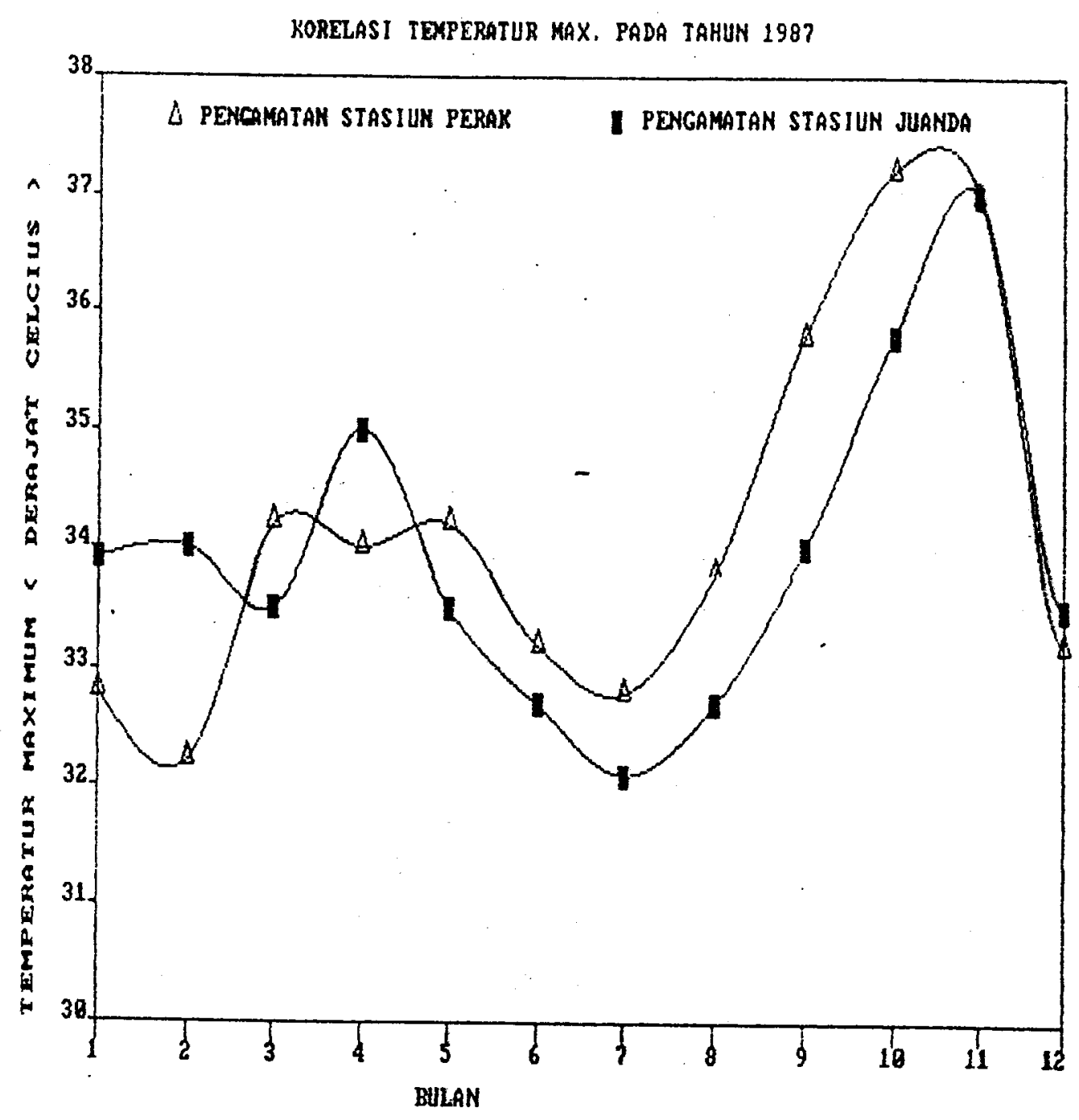

LAMPIRAN 1 
1.5 : GRAFIK TEMPERATUR BULANAN MAXIMUM PENGAMATAN STASIUN PERAK DAN PENGAMATAN STASIUN JUANDA 1981 - 1989

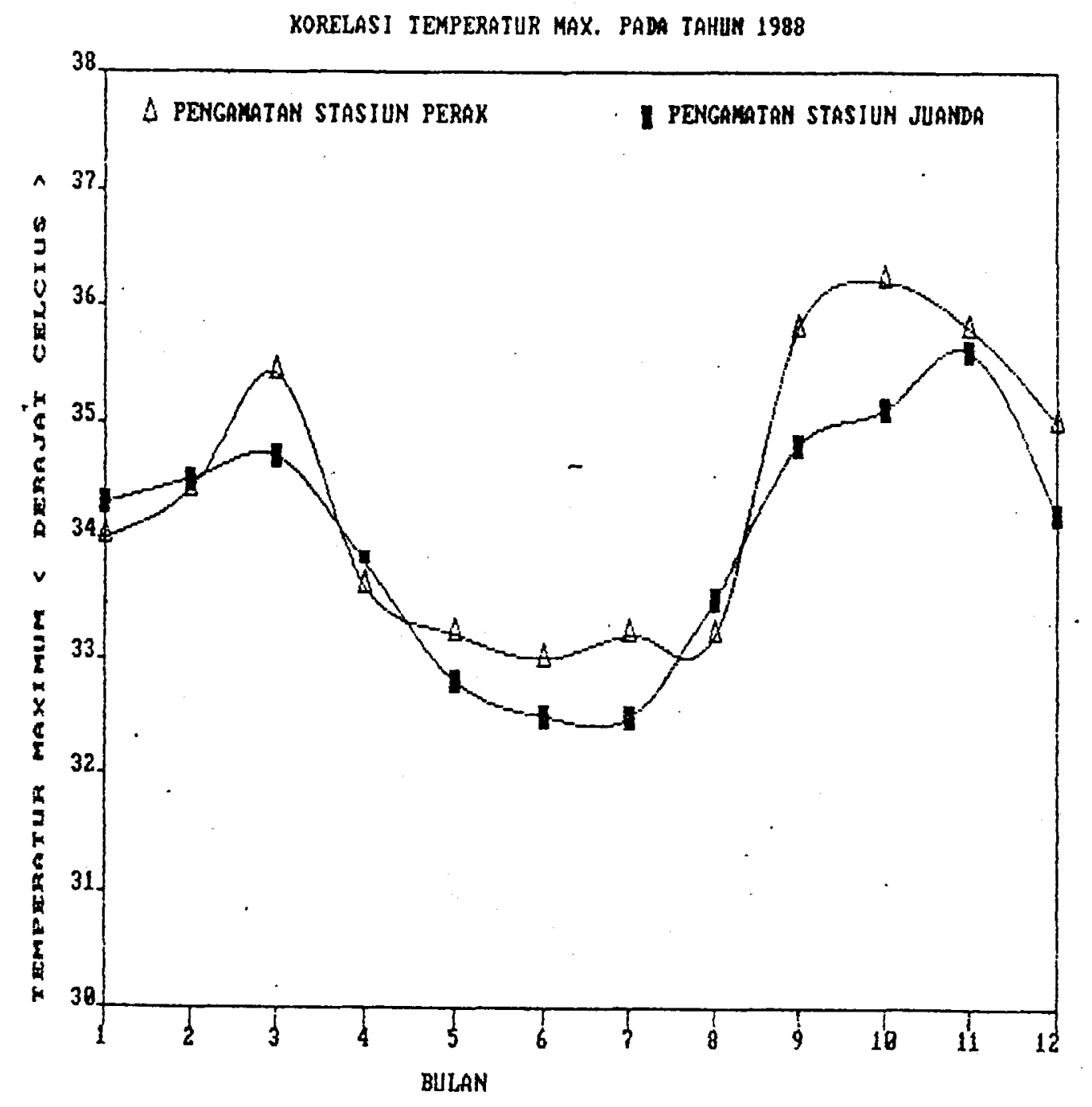

LAMPIRAN 1 
1.5 : GRAFIK TEMPERATUR BULANAN MAXIMUM PENGAMATAN STASIUN PERAK DAN PENGAMATAN STASIUN JUANDA 1981 - 1989

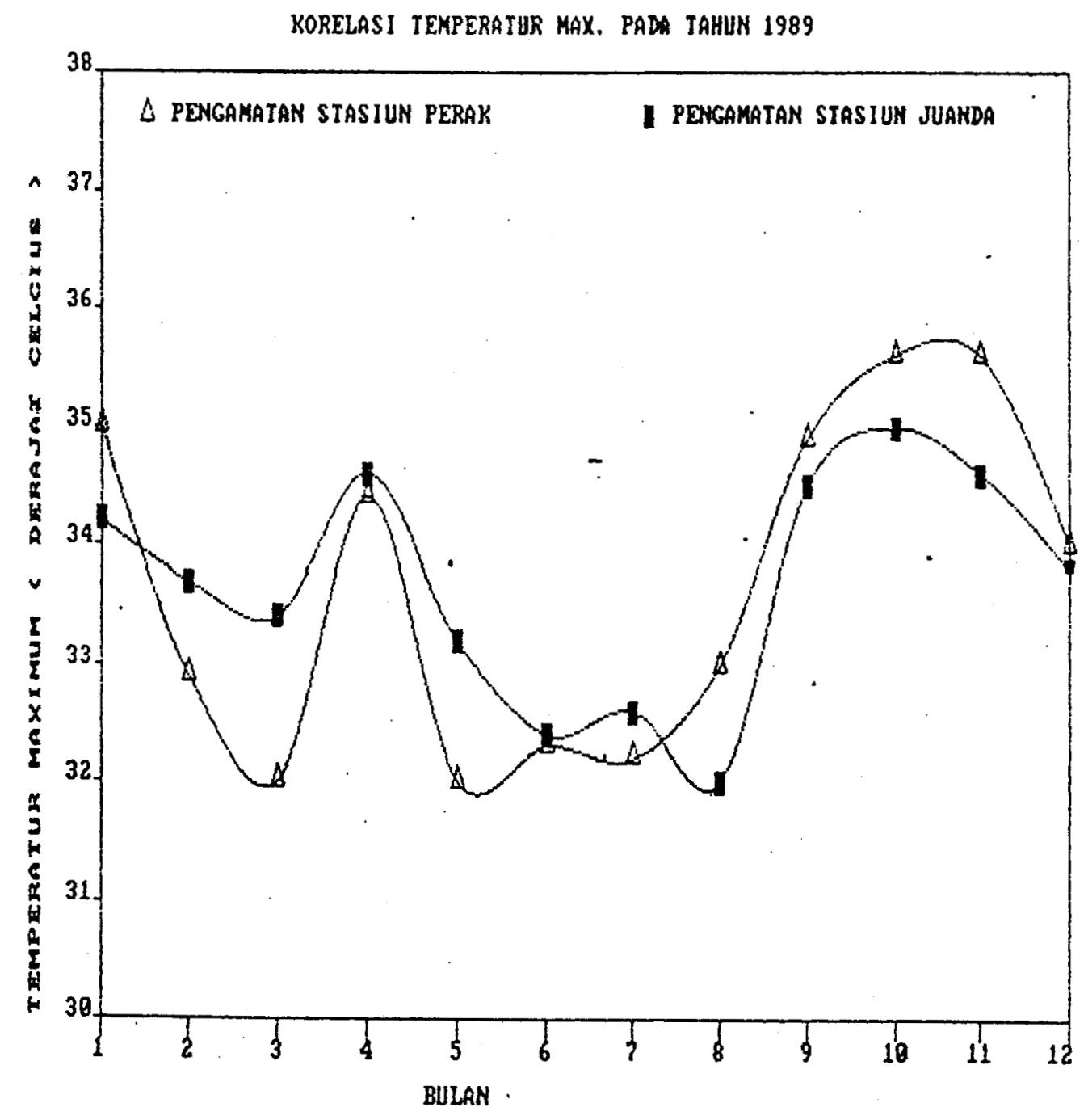

LAMPIRAN 1 
var iabel-e yang sal ing mempengaruhi

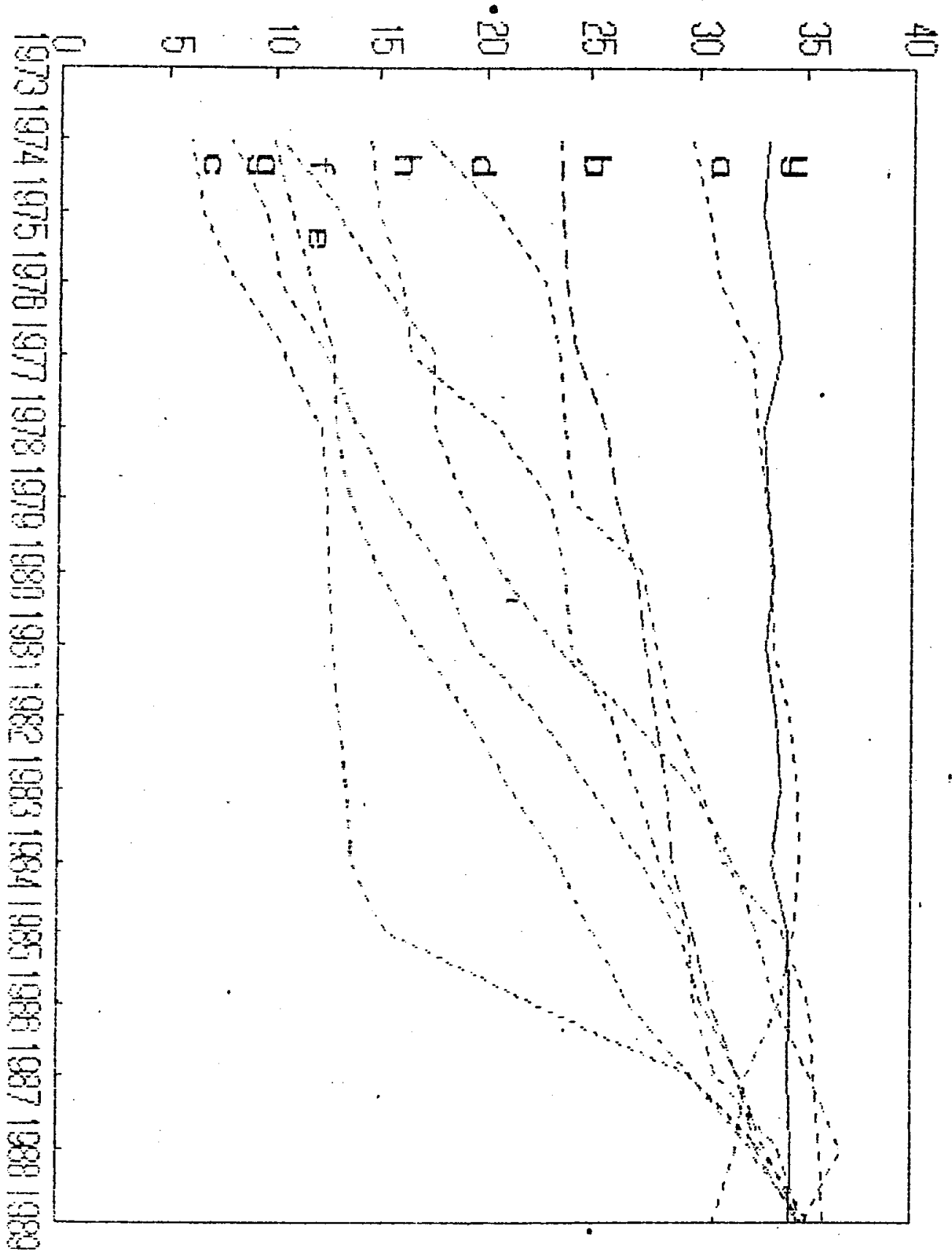

1.6. GFOHIU TEIFEFATIF DAU VAFIABEI BEGAS

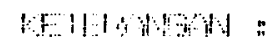

$Y$ : Subu, Temperatur
$A$ : Sawah dan tanah fosong
$B$ : Bangunan
$C$ : Industri
$D=$ Jalan
$E=$ Mobil
$F$ : Sepeda motor
$B$ : Truck
$H=$ Eus

St:ala $1: 1$

Ska a $1: 540$

St:a1a 1 : 410

Skala 1 : 38

Skala 1 : 12

Skala 1 : 2670

Ska 1 a. 1 : 8940

Skala 1 ; 1410

skala $1: 80$ 


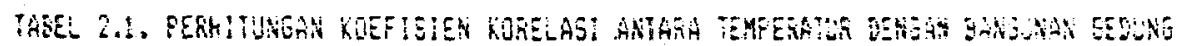

\begin{tabular}{|c|c|c|c|c|c|}
\hline \multicolumn{3}{|c|}{ 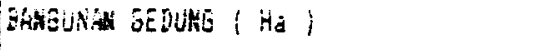 } & \multicolumn{3}{|c|}{ 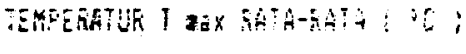 } \\
\hline TAHUN & $x$ & $x^{2}$ & $i$ & $n$ & $x y$ \\
\hline 1974 & $9,676,4$ & $93,632,717.0$ & 33.2 & $1,102.2$ & $321,256.5$ \\
\hline 1975 & $9,714.8$ & $94,377,339.0$ & 33.0 & $1,069.0$ & $\mathrm{~J} 20,588.4$ \\
\hline 1976 & $9,851,4$ & $.97,050,082.0$ & 33.5 & $1,122.3$ & $330,021.9$ \\
\hline 1977 & $10,052.7$ & $101,056,777.3$ & 33.8 & $1,142.4$ & $339,781.3$ \\
\hline 1978 & $10,573,6$ & $111,801,017.0$ & 33.1 & $1,095.6$ & $349,986.2$ \\
\hline 1979 & $10,786.4$ & $116,346,425.0$ & 33.3 & $1,108.9$ & $359,187.1$ \\
\hline 1980 & $11,147.5$ & $124,286,756.3$ & 33.6 & $1,129.0$ & $374,556.0$ \\
\hline 1981 & $11,321.8$ & $128,193,155.2$ & 33.2 & $1,102.2$ & $375,893.8$ \\
\hline 1982 & $11,531.2$ & $132,968,573.4$ & 33.7 & $1,135.7$ & $389,601.4$ \\
\hline 1983 & $11,764.8$ & $138,410,519.0$ & 33.9 & $1,149.2$ & $398,826.7$ \\
\hline 1984 & $11,896.4$ & $141,524,333,0$ & 33.5 & $1,122.3$ & $398,529.4$ \\
\hline 1985 & $12,276.7$ & $150,717,362.9$ & 34.2 & $1,169.6$ & $419,863.1$ \\
\hline 1986 & $12,573.6$ & $158,095,417,0$ & -34.3 & $1,176.5$ & $431,274.5$ \\
\hline 1987 & $13,147.3$ & $172,851,497.3$ & 34.2 & $1,169.6$ & $449,637.7$ \\
\hline 1988 & $13,473.6$ & $181,537,897.0$ & 34.4 & $1,183.4$ & $463,491.8$ \\
\hline 1989 & $14,268.0$ & $203,575,824.0$ & 34.3 & $1,178.5$ & $489,392.4$ \\
\hline JUKKLAY & $184,056.2$ & $2,146,395,692.2$ & 539.2 & $18,174,4$ & $6,210,878.2$ \\
\hline
\end{tabular}

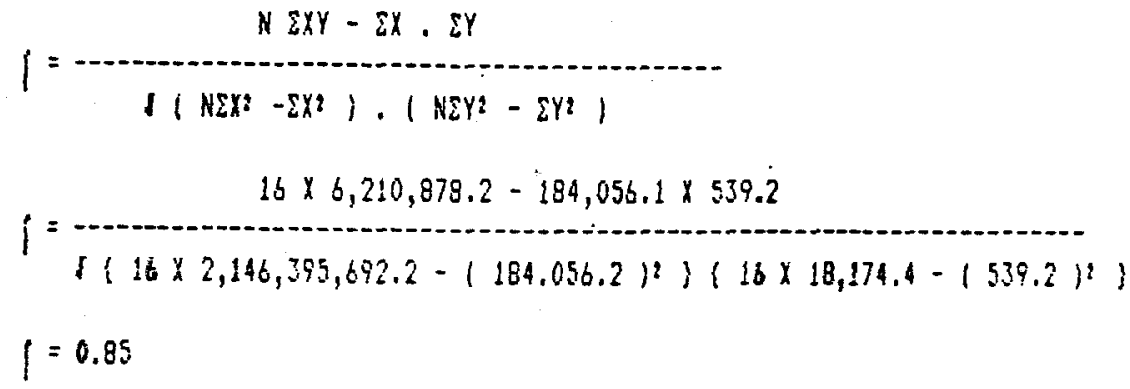

LAMFIKAN 2.1 
SAMBUNGGN LAMPIRAM $2.1 \ldots \ldots \ldots$.

TABEL 2.2 PERHITUNGAN KOEFISIEN KORELASI ANIARA TEMFERATUR DENGAN SAWAH DAN TANAH XOSONG

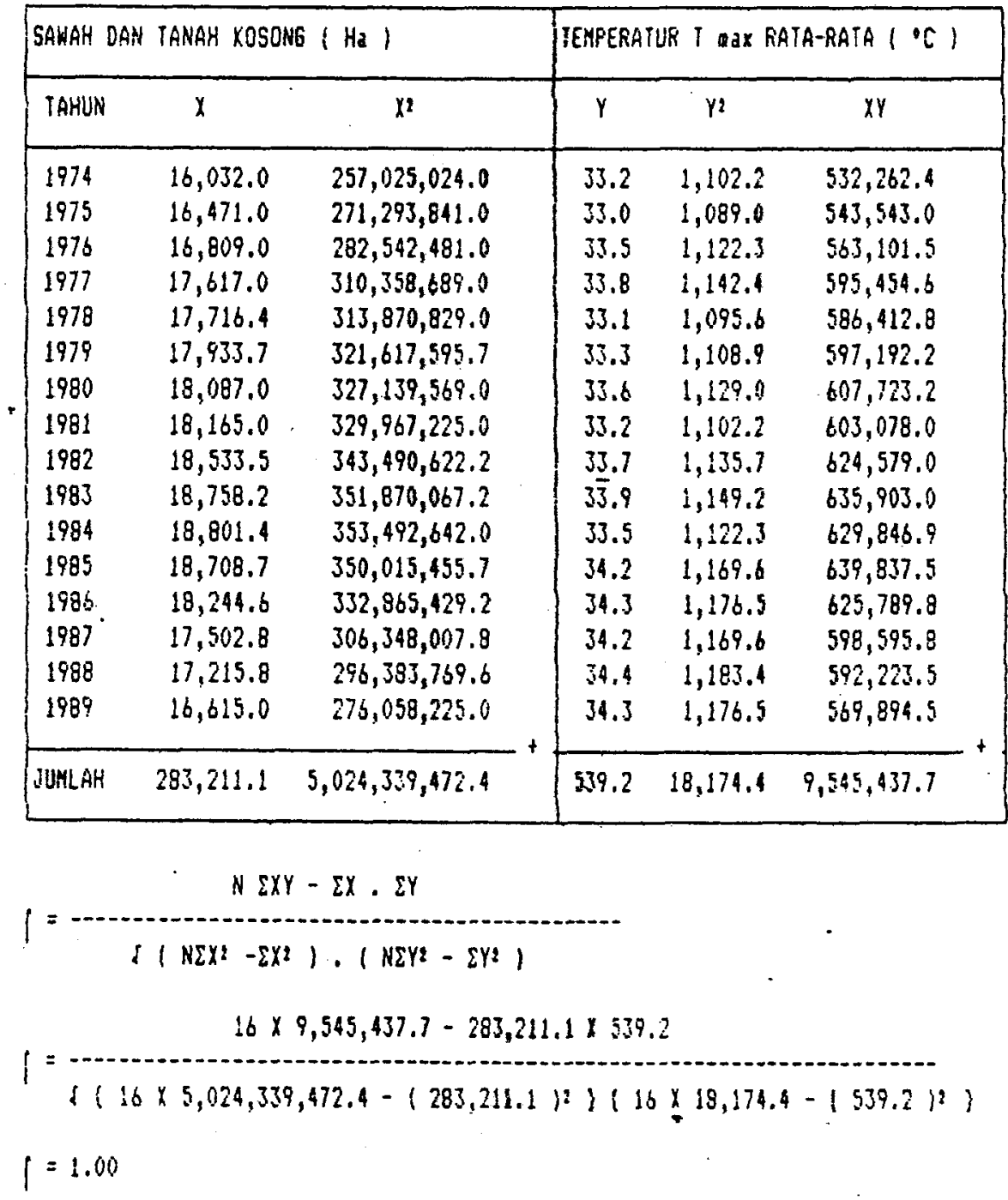


SAMEUNGAN LAMFIRAN $2.1 \ldots \ldots \ldots$

IABEL 2.3 FERHITUNGAN KOEFISIEN KGGELASI ANTARA TEKFERATUR DENGAN INOUSTR!

\begin{tabular}{|c|c|c|c|c|c|}
\hline \multirow{2}{*}{ INOUSTRI } & \multicolumn{2}{|l|}{$|\mathrm{Ha}|$} & \multicolumn{3}{|c|}{ IEMFERAATLK T AaX RGTA-RATA I 'C I } \\
\hline & 1 & $x:$ & $Y$ & $y^{:}$ & $x y$ \\
\hline 1974 & 227.0 & $51,529.0$ & 33.2 & $1,102.2$ & $7,536.4$ \\
\hline 1975 & 251.4 & $63,202.0$ & 33.0 & $1,089.0$ & $8,296.2$ \\
\hline 1976 & 314.8 & $99,099.0$ & 33.5 & $1,122.3$ & $10,545.8$ \\
\hline 1977 & 397.8 & $158,244.9$ & 33.8 & $1,142.4$ & $13,445.6$ \\
\hline 1978 & 467.1 & $218,182.4$ & 33.1 & $1,095.6$ & $15,4 b 1.0$ \\
\hline 1979 & 476.0 & $226,576.0$ & $33: 3$ & $1,108,9$ & $15,890,8$ \\
\hline 1990 & 480.3 & $230,688.1$ & 33.6 & $1,129.0$ & $26,138.1$ \\
\hline 1981 & 486.7 & $236,976.9$ & 33.2 & $1,102,2$ & $26,158.4$ \\
\hline 1982 & 498.1 & $248,103.6$ & 33.7 & $1,135.7$ & $16,786,0$ \\
\hline 1983 & 513.3 & $263,476.9=$ & 33.9 & $1,149.2$ & $\$ 7,400.9$ \\
\hline 1984 & 523.7 & $274,261.7$ & 33.5 & $1,122.3$ & $17,544.0$ \\
\hline 1985 & 590.5 & $348,690.3$ & 34.2 & $1,169,6$. & $20,195.1$ \\
\hline $198 b$ & 855.3 & $731,538.1$ & 34.3 & $1,176.5$ & $29,336.8$ \\
\hline 1987 & $1,129.7$ & $1,276,222.1$ & 34.2 & $1,169.6$ & $38,635.7$ \\
\hline 1988 & $1,258.7$ & $1,584,325.7$ & 34.4 & $1,183,4$ & $43,299.3$ \\
\hline 1989 & $1,335.7$ & $1,794,094.5$ & 34.3 & $1,178.5$ & $45,814.5$ \\
\hline JUMLAH & $9,806.1$ & . $7,785,111.0$ & 539.2 & $18,174.4$ & $332,444.6$ \\
\hline
\end{tabular}

$$
\begin{aligned}
& \text { N } \Sigma X Y-\Sigma X \cdot I T
\end{aligned}
$$

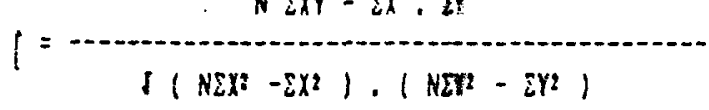

$$
\begin{aligned}
& 16 \times 332,444.6-9,805.1 \times 539.2 \\
& l=\{(16 \times 7,795,111.0-(9,00.1)\}\{\text { is } \times 18,174,4-(539,2)\} \\
& 1=0.85
\end{aligned}
$$


SAMBUNGAN LAKPIREM $2.1 \ldots \ldots \ldots$.

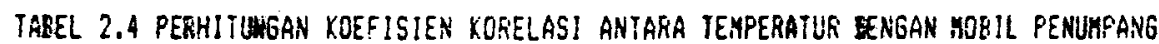

\begin{tabular}{|c|c|c|c|c|c|}
\hline \multicolumn{3}{|c|}{ MOBIL PENUMPANG } & \multicolumn{3}{|c|}{ IEMFERATUR T RATA-RATA ('C) } \\
\hline TAHUN & $x$ & $x^{2}$ & Y & $\mathrm{YZ}^{2}$ & $X Y$ \\
\hline 1974 & $26,522.0$ & $703,416,484.0$ & 33.2 & $1,102.2$ & $880,530,4$ \\
\hline 1975 & $28,923.0$ & $836,539,929.0$ & 33.0 & $1,089.8$ & $954,459.0$ \\
\hline 1976 & $31,639.0$ & $1,001,026,321.0$ & 33.5 & $1,122.3$ & $1,059,906,5$ \\
\hline 1977 & $34,102.0$ & $1,162,946,404.0$ & 33.8 & $1,142.4$ & $1,152,647.5$ \\
\hline 1978 & $34,374.0$ & $1,181,571,676.0$ & 33.1 & $1,095.6$ & $1,137,779.4$ \\
\hline 1979 & $36,714.0$ & $1,347,917,796.0$ & 33.3 & $1,108.9$ & $1,222,576.2$ \\
\hline 1980 & $40,639.0$ & $1,651,528,321.0$ & 33.6 & $1,129.4$ & $1,355,470.4$ \\
\hline 1981 & $45,267.0$ & $2,049,101,289.0$ & 33.2 & $1,102.8$ & $1,502,864,4$ \\
\hline 1982 & $51,907.0$ & $2,694,336,649,0$ & 33.7 & $1,135.7$ & $1,749,265.9$ \\
\hline 1993 & $57,257.0$ & $3,278,364,049.0$ & 33.9 & $1,149.2$ & $1,941,012.3$ \\
\hline 1984 & $63,010.0$ & $3,970,260,100.0$ & 33.5 & $1,122 . \mathrm{z}$ & $2,120,635,1$ \\
\hline 1785 & $87,473.0$ & $4,552,605,729.0$ & 34.2 & $1,269.6$ & $2,307,576.6$ \\
\hline 1986 & $11,969.0$ & $5,179,536,961.0$ & 34.3 & $1,176.5$ & $2,468,536.7$ \\
\hline 1987 & $79,336.0$ & $6,294,200,896.0$ & 34.2 & $1,169.5$ & $2,313,291.2$ \\
\hline 1988 & $87,138.0$ & $7,593,031,044,0$ & 34.4 & $1,183.4$ & $2,997,547.2$ \\
\hline$! 989$ & $93,214.0$ & $8,688,849,796.0$ & 34.3 & $1,17 t .5$ & $3,197,240.2$ \\
\hline JUHLAH & $849,494.0$ & $52,185,233,644.0$ & 539.2 & $18,174.6$ & $28,761,539.0$ \\
\hline
\end{tabular}

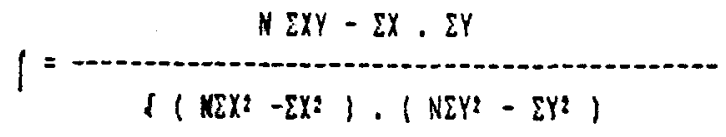

$16 \times 28,761,539.0-849,484 \times 539.2$

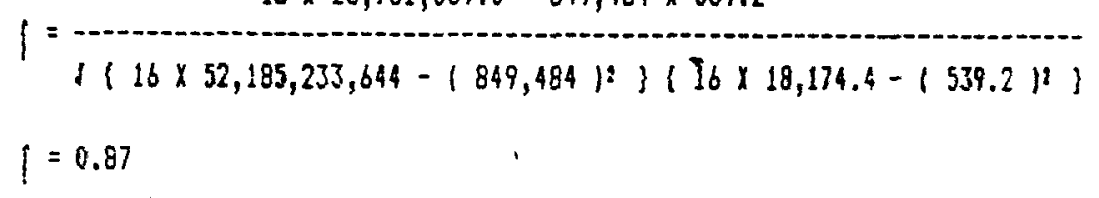


SAMBUNGAN LAMPIRAK $2.1 \ldots \ldots . .$.

TABEL 2.5 PERHITUNGAN KOEFISIEN XORELAS! ANTAGA TEKPERATUS DENGAN SEFEDA MOTOR

\begin{tabular}{|c|c|c|c|c|c|}
\hline \multicolumn{3}{|c|}{ SEPEDA MOTOR } & \multicolumn{3}{|c|}{ TEMPERATUK I $\triangle 3 \times$ SATA-RATA（'C । } \\
\hline TAHUN & $x$ & $x^{2}$ & $\gamma$ & $y^{2}$ & $X Y$ \\
\hline 1974 & $91,639.0$ & $8,397,706,321.0$ & 33.2 & $1,102.2$ & $3,042,414,8$ \\
\hline 1975 & $114,699.0$ & $13,155,860,601.0$ & 33.0 & $1,089,0$ & $3,785,067.0$ \\
\hline 1976 & $134,042.0$ & $17,967,257,764.0$ & 33.5 & $1,122.3$ & $4,490,407.0$ \\
\hline 1977 & $155,253.0$ & $24,105,599,169.0$ & 33.9 & $1,142.4$ & $5,247,889.4$ \\
\hline 1978 & $156,455.0$ & $24,478,167,025.0$ & 33.1 & $1,095.6$ & $5,178,660.5$ \\
\hline 1979 & $169,085.0$ & $28,589,737,225.0$ & 33.3 & $1,108.9$ & $5,630,530.5$ \\
\hline 1980 & $184,424.0$ & $34,032,211,776.0$ & 33.6 & $1,129.0$ & $6,196,646,4$ \\
\hline 1981 & $206,926.0$ & $42,818,369,476.0-$ & 33.2 & $1,102,2$ & $6,869,943.2$ \\
\hline 1982 & $238,931.0$ & $57,088,022,761.0$ & 33.7 & $1,135.7$ & $8,051,974.7$ \\
\hline 1983 & $264,269.0$ & $69,838,104,351.0$ & 33.9 & $1,149.2$ & $8,758,719.1$ \\
\hline 1984 & $280,971.0$ & $78,944,702,841.0$ & 33.5 & $1,122.3$ & $9,412,528.5$ \\
\hline 1985 & $290,650.0$ & $84,477,422,500.0$ & 34.2 & $1,167.6$ & $9,940,230.0$ \\
\hline 1986 & $297,801.0$ & $88,685,435,601.0$ & 34.3 & $1,176.5$ & $10,214,574.3$ \\
\hline 1987 & $312,421.0$ & $97,606,88 !, 24 ! .0$ & 34.2 & $1,169.6$ & $10,684,798.2$ \\
\hline 1988 & $324,833.0$ & $105,516,477,889.0$. & 34.4 & $1,183.4$ & $11,174,255.2$ \\
\hline 1989 & $309,287.0$ & $95,658,448,369.0$ & 34.3 & $1,176.5$ & $10,608,544.1$ \\
\hline \multicolumn{3}{|c|}{$3,531,696,0871,341,404,930.0$} & 539.2 & \multicolumn{2}{|c|}{$18,174.4119,487,182.9$} \\
\hline
\end{tabular}

$N \Sigma X Y-\Sigma X, \Sigma Y$

$1=\frac{1\left(N E X^{2}-2 X^{2}\right) \cdot\left(N E Y^{2}-E Y^{2}\right)}{n-2}$

$16 \times 119,487,192.9-3,531,646 \times 539.2$

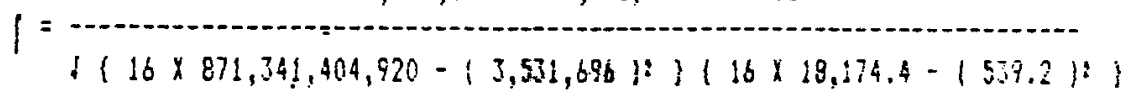

$1=0.88$ 
SAHSUNGAN LAMPIRAN $2.1 \ldots \ldots \ldots$.

TAGEL 2.6 PEEHITUHGAN KOEF ISIEN KORELASI ANTARA TEMFERIUUT DENGAN IRUCK / MOBIL BEEAN

\begin{tabular}{|c|c|c|c|c|c|}
\hline \multirow{2}{*}{$\frac{\text { IRUCK }}{\text { TAHUN }}$} & \multicolumn{2}{|c|}{ MOBIL PEBAN } & \multicolumn{3}{|c|}{ IEMPERATUR T ada RATA-RATA ( 'C } \\
\hline & $x$ & $x^{2}$ & Y & $y^{2}$ & $x y$ \\
\hline 1974 & $11,316.0$ & $128,051,856,0$ & 33.2 & $1,102.2$ & $375,691.2$ \\
\hline 1975 & $13,534.0$ & $183,169,156.0$ & 33.0 & $1,089.0$ & $146,622.0$ \\
\hline 1976 & $14,572.0$ & $212,343,184.0$ & 33.5 & $1,122.3$ & $489,162.0$ \\
\hline 1977 & $17,524,0$ & $307,090,576.0$ & 33.8 & $1,142.4$ & $592,311.2$ \\
\hline 1978 & $19,828.0$ & $393,149,584.0$ & 33.1 & $1,095.6$ & $656,306.8$ \\
\hline 1979 & $n, 100.0$ & $488,410,000.0$ & 33.3 & $\$, 108.9$ & $735,930.0$ \\
\hline 1980 & $75,514.0$ & $650,954,196.0$ & 33.6 & $1,129.0$ & $857,270.4$ \\
\hline 1981 & $27,506.0$ & $756,580,036.0$ & 33.2 & $1,102.2$ & $913,199.2$ \\
\hline 1982 & $\$ 2,076.0$ & $1,028,869,776,0-$ & 33.7 & $\$, 135.7$ & $1,080,861.2$ \\
\hline 1983 & $35,334.0$ & $1,248,491,556.0$ & 33.9 & $1,149.2$ & $1,197,822.6$ \\
\hline 1984 & $38,836.0$ & $1,508,234,896.0$ & 33.5 & $1,122.3$ & $1,301,006.0$ \\
\hline 1985 & $11,364.0$ & $1,710,980,496.0$ & 34.2 & $1,169.6$ & $1,414,648.8$ \\
\hline 1986 & $\$ 2,749.0$ & $1,827,477,001.0$ & 34.3 & $1,176.5$ & $1,466,290.7$ \\
\hline 1987 & $45,211.0$ & $2,044,034,521.0$ & 34.2 & $1,169.6$ & $1,546,216.2$ \\
\hline$\$ 988$ & 被, 981.0 & $2,207,214,361.0$ & 34.4 & $1,183.4$ & $1,616,146,4$ \\
\hline 1989 & $49,345.0$ & $2,434,929,025.0$ & 34.3 & $1,176.5$ & $1,692,533.5$ \\
\hline JUMLAH & $483,790.0$ & $17,129,990,220.0$ & 539.2 & $18,174.4$ & $16,381,118.2$ \\
\hline
\end{tabular}

$$
\begin{aligned}
& H \Sigma X Y-\Sigma X \cdot \Sigma Y \\
& f=\int\left(E X^{2}-E X^{2}\right)\left(n E Y^{2}-E Y^{2}\right) \\
& 16 \times 16,381,118.2-493,790 \times 539.2 \\
& f=\{\{16 \times 17,129,990,220-(483,790)\} ;\{16 \times 18,174.4-\{539.2\}\} \\
& i=0.85
\end{aligned}
$$


SaMBUMGaN LAMPIRAN $2.1 \ldots \ldots \ldots$.

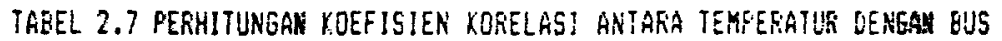

\begin{tabular}{|c|c|c|c|c|c|}
\hline \multicolumn{3}{|l|}{ EUS } & \multicolumn{3}{|c|}{ IEMFEKATUR T QdX RATA-RATG I 'C } \\
\hline TAHUK & $x$ & $x^{2}$ & $y$ & $\gamma:$ & IY \\
\hline 1974 & $1,166.0$ & $1,359,556.0$ & 33.2 & $1,102.2$ & $38,711.2$ \\
\hline 1975 & $1,203.0$ & $1,447,209.0$ & 33.0 & $1,089.0$ & $39,699.0$ \\
\hline 1976 & $1,291.0$ & $1,666,681.0$ & 33.5 & $1,122.3$ & $43,248.5$ \\
\hline 1977 & $1,317.0$ & $1,734,489.0$ & 33.8 & $1,142.4$ & $44,514.6$ \\
\hline 1978 & $1,656.0$ & $2,742,336.0$ & 33.1 & $1,095.6$ & $54,813.6$ \\
\hline 1979 & $1,855.0$ & $3,441,025.0$ & 33.3 & $1,108.9$ & $61,771.5$ \\
\hline 1980 & $1,914.0$ & $3,663,396,0$ & 33.6 & $1,129.0$ & $64,310.4$ \\
\hline 1981 & $1,936.0$ & $3,748,096.0$ & 33.2 & $1,102.2$ & $64,275.2$ \\
\hline 1982 & $2,087.0$ & $4,355,569.0$ & 33.7 & $1,135.7$ & $70,331.9$ \\
\hline 1983 & $2,180.0$ & $4,752,400,0$ & 33.9 & $1,149.2$ & $73,902.0$ \\
\hline 1984 & $2,271.0$ & $5,157,441.0$ & 33.5 & $1,122.3$ & $76,078.5$ \\
\hline 1985 & $2,376.0$ & $5,645,376.0$ & 34.2 & $1,969.6$ & $81,259.2$ \\
\hline 1986 & $2,403.0$ & $5,774,409,0$ & 34.3 & $1,176.5$ & $82,422.9$ \\
\hline 1987 & $2,183.0$ & $6,165,289.0$ & 34.2 & $2,169.6$ & $84,918.6$ \\
\hline 1988 & $2,701.0$ & $7,275,401.0$ & 34.4 & $1,183.4$ & $92,814.4$ \\
\hline 1989 & $2,799.0$ & $7,834,401.0$ & 34.3 & $2,176.5$ & $96,005.7$ \\
\hline SURLAH & $34,638.0$ & $66,793,074.0$ & 539.2 & $18,174,4$ & $1,069,177.2$ \\
\hline
\end{tabular}

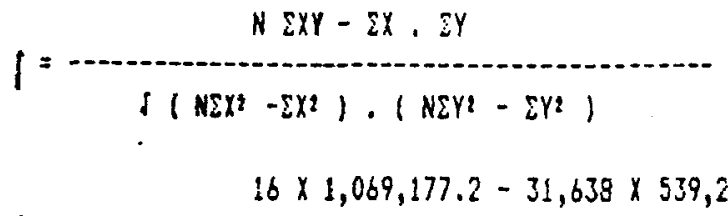

$f=\left\{\left\{16 \times 66,783,074-\left(31,638 i^{2}\right)\{16 \times 18,174.4-(539.2\})\right.\right.$

$1=0.79$ 
SAMBUNGAN LAMPIRAN $2.1 \ldots \ldots \ldots \ldots$

TABEL 2.8 PERHITUNGAN KOEFISIEN XORELAS! ANTARA TEMPESATUR DENGAN JALAN

\begin{tabular}{|c|c|c|c|c|c|}
\hline \multicolumn{3}{|l|}{ JALAN } & \multicolumn{3}{|c|}{ TENPERATUR T :aX KATA-RATA ( 'C I } \\
\hline TAHUN & $x$ & $x^{2}$ & $Y$ & $Y z$ & $X Y$ \\
\hline 1974 & 208.7 & $43,555.7$ & 33.2 & $1,102.2$ & $6,928.8$ \\
\hline 1975 & 248.5 & $61,757.2$ & 33.0 & $1,089.0$ & $8,200.8$ \\
\hline 1976 & 274.3 & $75,240.5$ & 33.5 & $1,122.3$ & $9,189.1$ \\
\hline 1977 & 283.7 & $80,485.7$ & 33.8 & $1,142.4$ & $9,589.1$ \\
\hline 1978 & 287.2 & $82,483.8$ & 33.1 & $1,095.6$ & $9,506.3$ \\
\hline 1978 & 291.0 & $84,681.0$ & 33.3 & $1,108.9$ & $9,690.3$ \\
\hline 1980 & 330.4 & $109,164.2$ & 33.6 & $1,129.0$ & $11,101.1$ \\
\hline 1981 & 338.7 & $114,717.7-$ & 33.2 & $1,102.2$ & $11,244.8$ \\
\hline 1982 & 346.2 & $119,854.4$ & 33.7 & $1,135.7$ & $11,666.9$ \\
\hline 1983 & 363.5 & $132,132.3$ & 33.9 & $1,149.2$ & $12,322.6$ \\
\hline 1984 & 375.1 & $140,700.0$ & 33.5 & $1,122.3$ & $12,565.9$ \\
\hline 1985 & 407.5 & $166,056.3$ & 34.2 & $1,169.6$ & $13,936.5$ \\
\hline 1986 & 423.2 & $179,098.2$ & 34.3 & $1,176.5$ & $14,515.8$ \\
\hline 1987 & $42 b .1$ & $181,817.0$ & 34.2 & $1,159.6$ & $14,582.9$ \\
\hline 1988 & 430.0 & $184,900.0$ & 34.4 & $1,183.4$ & $14,792.0$ \\
\hline $1989^{\circ}$ & 430.3 & $185,158.1$ & 34.3 & $1,176.5$ & $14,759.3$ \\
\hline JUMLAH & $5,464.7$ & $1,941,802.0$ & 539.2 & $19,174.4$ & $184,592.6$ \\
\hline
\end{tabular}

$$
\begin{aligned}
& N \Sigma X Y-\Sigma X \cdot \Sigma Y \\
& 1=\left\{\left(N E X^{2}-\Sigma X^{2}\right) \cdot\left(N E Y^{2}-\Sigma Y^{2}\right)\right. \\
& 16 \times 184,592.6-5,464.7 \geq 539,2 \\
& 1=\left\{16 \times 1,941,802-(5,164.7)^{2}\right\}\left\{16 \times 19,174.4-(539.2)^{2}\right\} \\
& \Gamma=0.86
\end{aligned}
$$




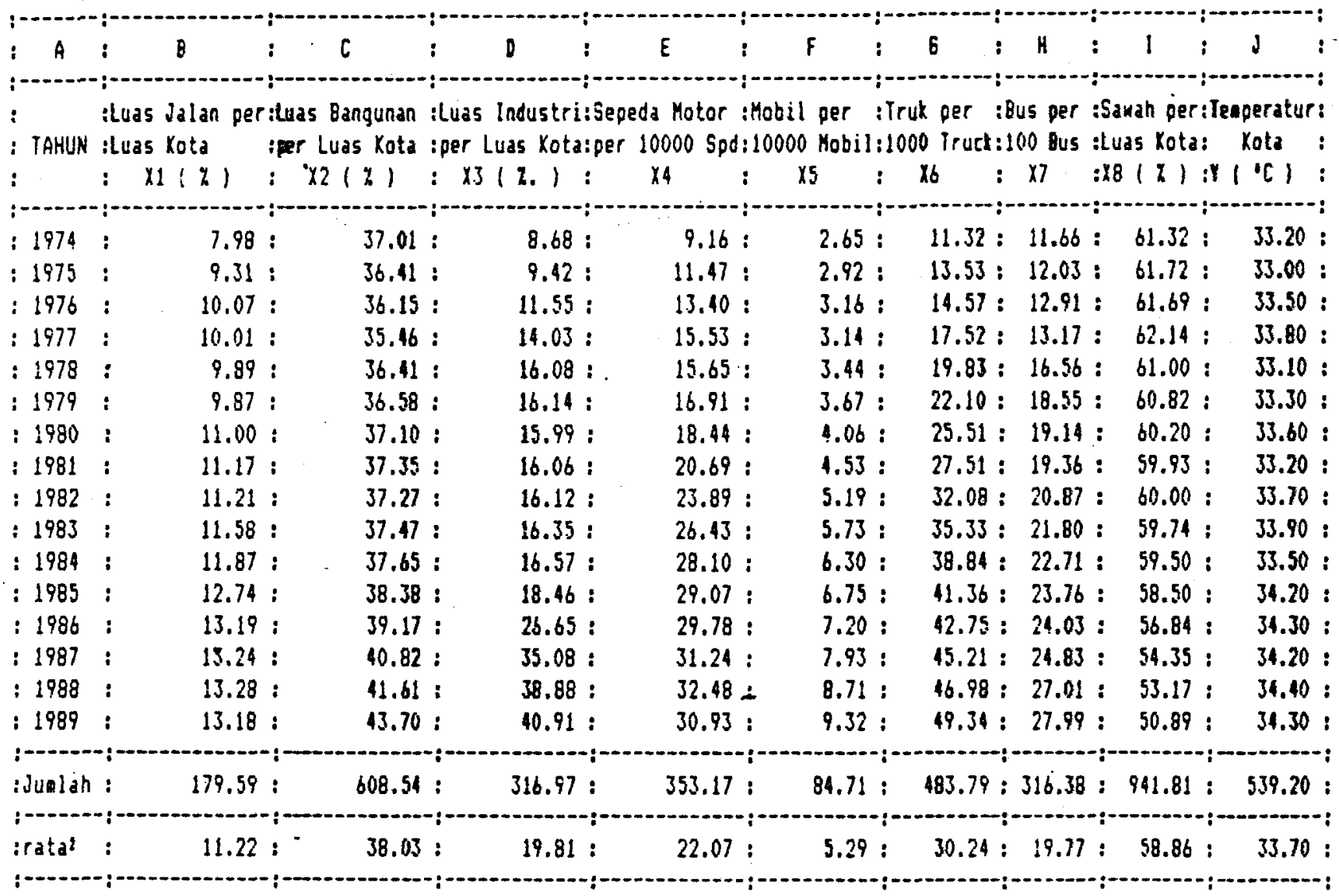

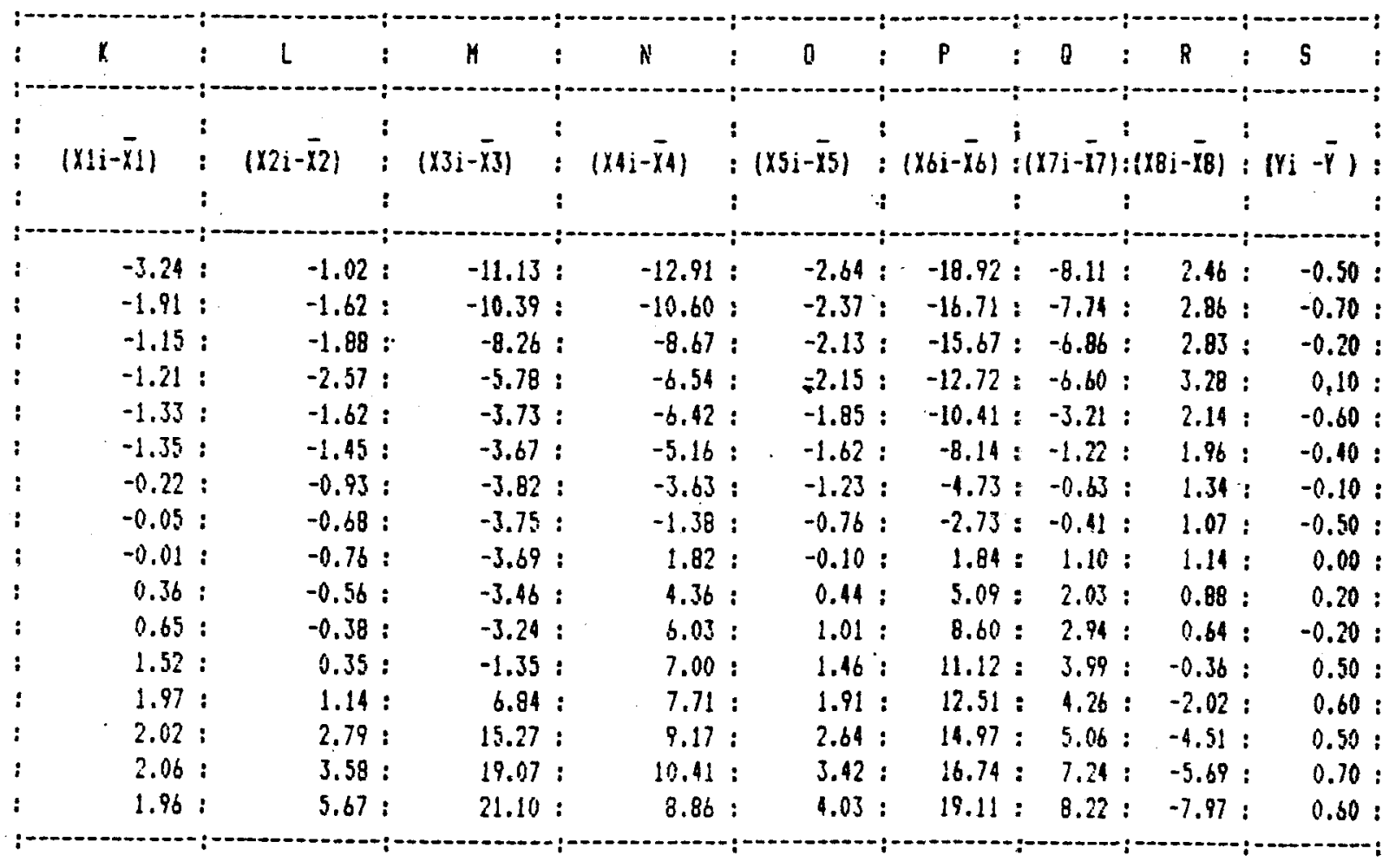


Sanbungan Laapiran $2.2 \ldots \ldots \ldots$

\begin{tabular}{|c|c|c|c|c|c|c|c|c|c|}
\hline & bil & $: 612=\$ 21:$ & $:\{1\}$ & & $1: \delta 15=851$ & $816=\$ 61:$ & $7=8$ & $18=681:$ & al \\
\hline & $k^{2}$ & $: K \times L$ & $: K$ & $x: k$ & $=1 \times 0$ & $K \times P:$ & $K \times 0=$ & $K * R=$ & $x \times 5$ \\
\hline & 10.50 & $3.30:$ & $36.06:$ & 41.82 & 8.55 & $61.31:$ & $26.28:$ & -7.97 : & 2.62 \\
\hline & 3.65 & 3.09 & $19.84:$ & 20.25 & 4.52 & $31.91:$ & $14.78:$ & $-5.46:$ & 1.34 \\
\hline & 1.32 & 2.16 & $9.50:$ & 9.97 & 2.45 & $18.02:$ & $7.89:$ & $-3.25:$ & $0.23:$ \\
\hline & 1.45 & 3.11 & $6.99:$ & 7.92 & 2.60 & $15.39:$ & $7.99:$ & $-3.97:$ & $-0.12:$ \\
\hline & 1.77 & 2.15 & $4.96:$ & 8.54 & 2.46 & $13.85:$ & 4.27: & $-2.85:$ & $0.80:$ \\
\hline & 1.82 & 1.96 & $4.95:$ & 6.97 & 2.19 & $10.99:$ & $1.65:$ & $-2.65:$ & $0.54:$ \\
\hline & 0.05 & 0.20 & $0.84:$ & 0.80 & 0.27 & $1.04:$ & $0.14:$ & $-0.29:$ & 0.02 \\
\hline & 0.00 & 0.03 & $0.19:$ & 0.07 & 0.04 & $0.14:$ & $0.02 ;$ & $-0.05:$ & $0.03:$ \\
\hline & 0.00 & 0.01 & $0.04:$ & -0.02 & 0.00 & $-0.02:$ & $-0.01:$ & $-0.01:$ & 0.00 \\
\hline & 0.13 & -0.20 & $-1.25:$ & 1.57 & 0.16 & $1.83:$ & $0.73:$ & $0.32 ;$ & 0.07 \\
\hline & 0.42 & -0.25 & $-2.11 ;$ & 3.92 & 0.66 & $5.59:$ & $1.91 ;$ & $0.42:$ & -0.13 \\
\hline & 2.31 & 0.53 & -2.05 & 10.63 & 2.22 & $16.91:$ & $6.06:$ & -0.55 ; & 0.76 \\
\hline & 3.88 & 2.25 & 13.47: & 15.19 & -3.76 & $24.64:$ & $8.39:$ & $-3.98:$ & 1.18 \\
\hline & 4.08 & 5.84 & 30.85 & 18.53 & 5.34 & $30.24:$ & $10.22 ;$ & $-9.11:$ & 1.01 \\
\hline & .4 .24 & 7.37 & $39.2 B:$ & 21.15 & 7.05 & $34.19:$ & $14.91 \mathrm{i}$ & $-11.72:$ & 1.44 \\
\hline & 3.84 & 11.06 & 41.06: & 17.12 & 7.49 & $37.05:$ & $16.03:$ & $-15.62:$ & 1.18 \\
\hline & & & & & & & & & 7.76 \\
\hline
\end{tabular}

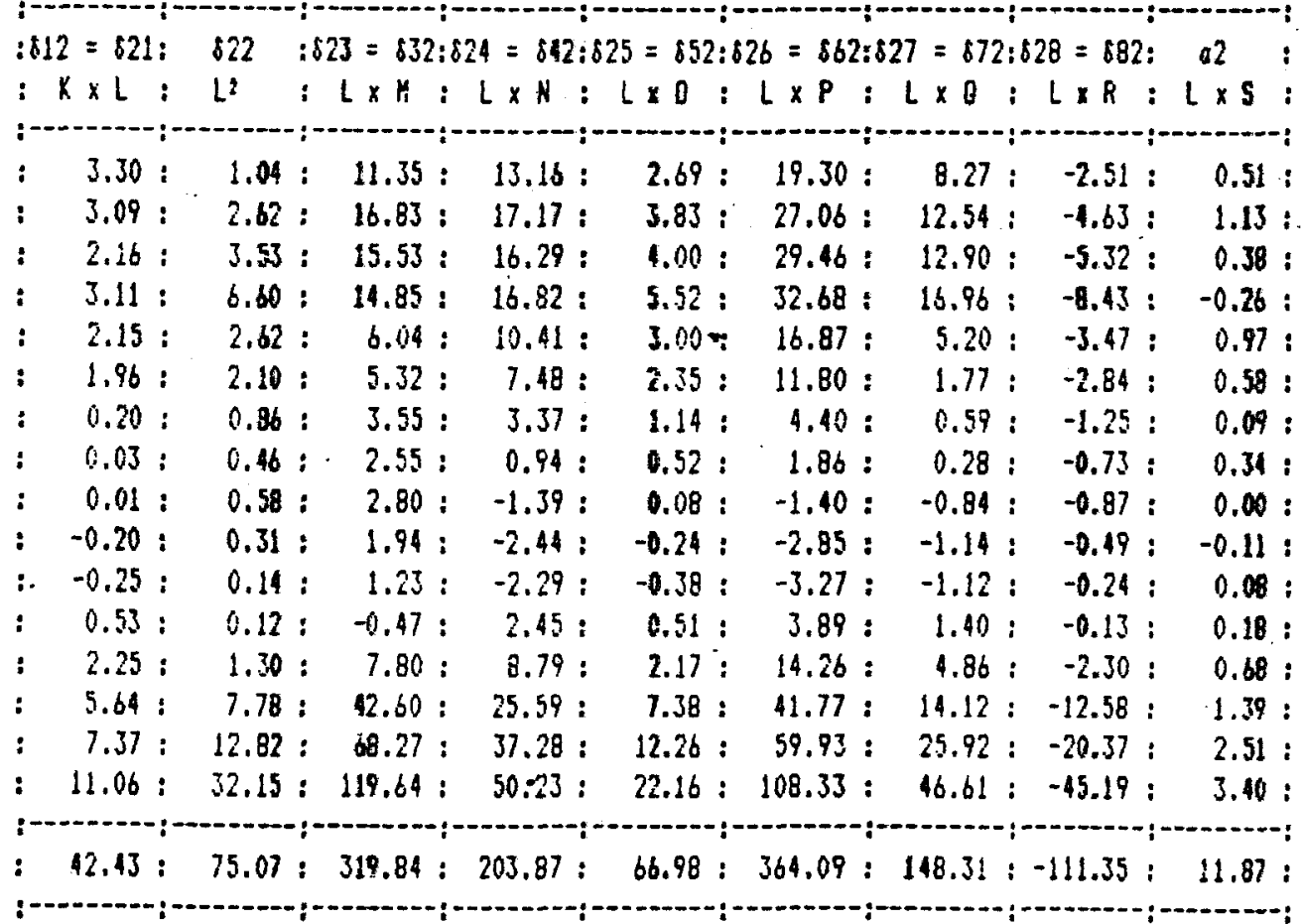




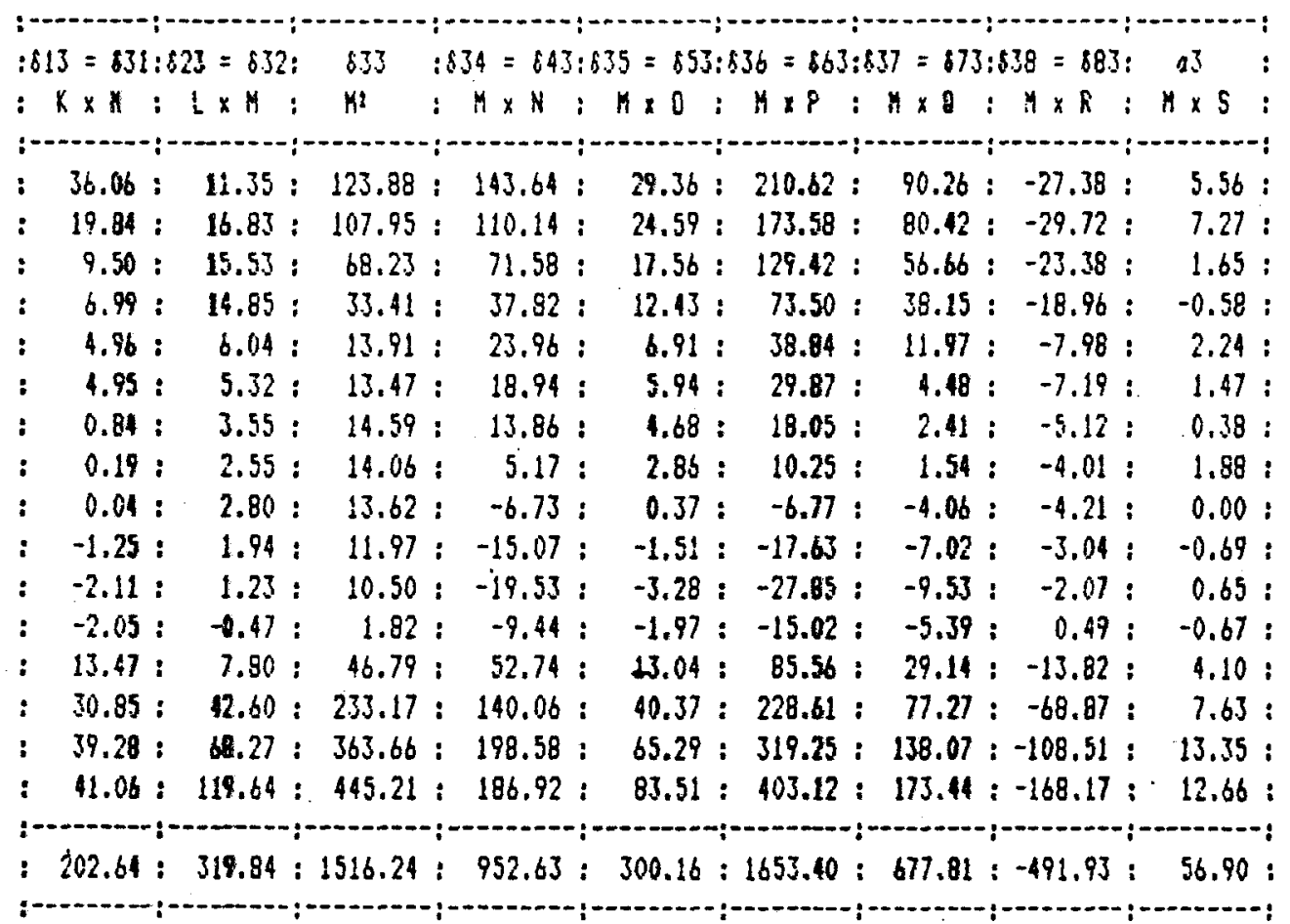

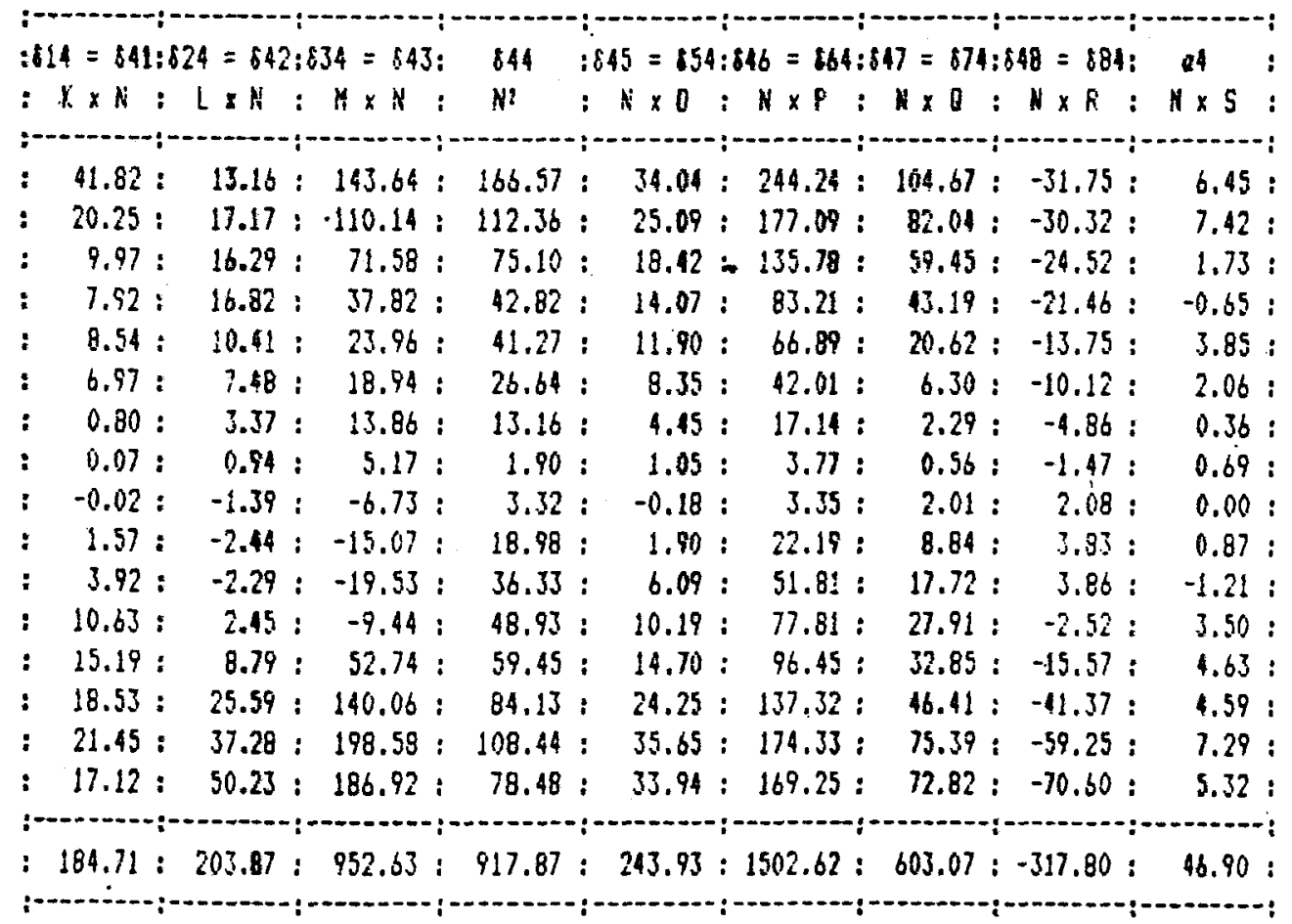


Sabungẹan Lampiran $2.2 \ldots \ldots \ldots$

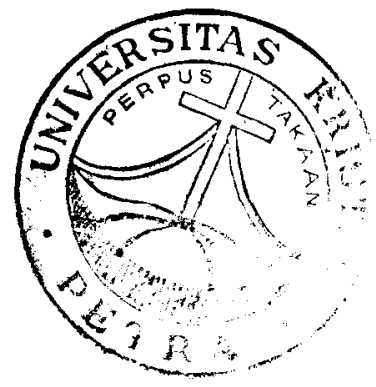

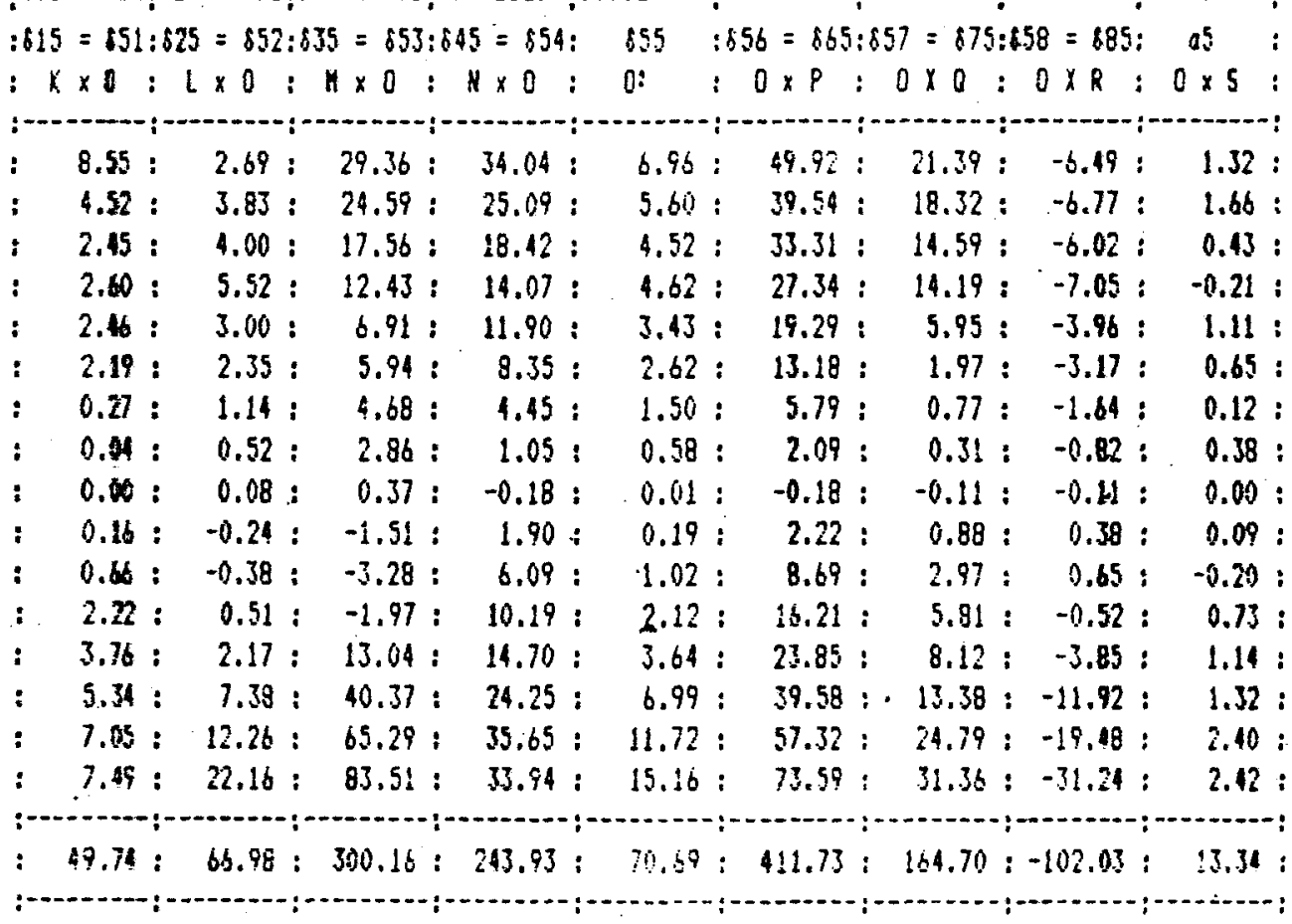

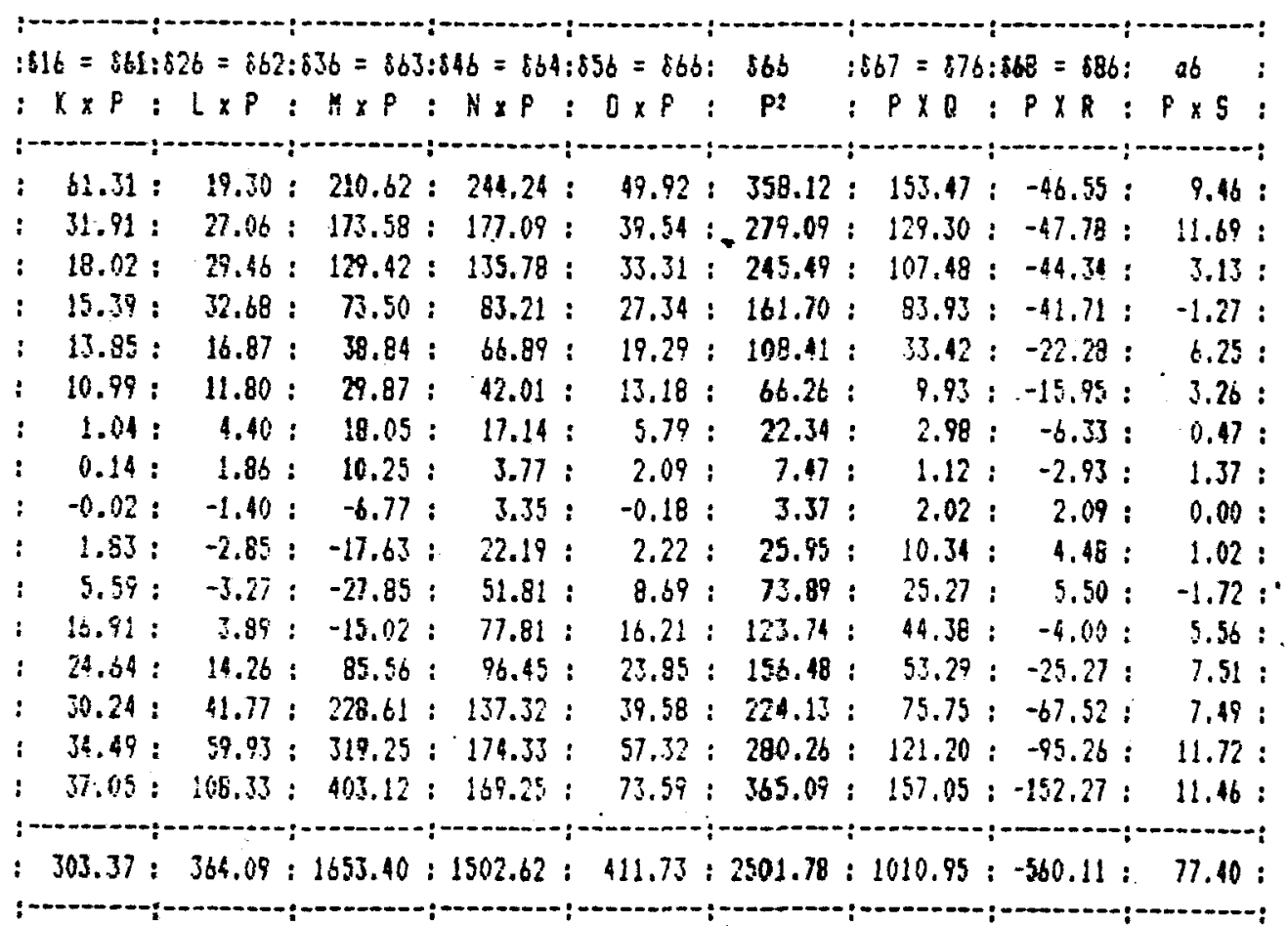


Sonbuģan Leapiran $2.2 \ldots \ldots \ldots$

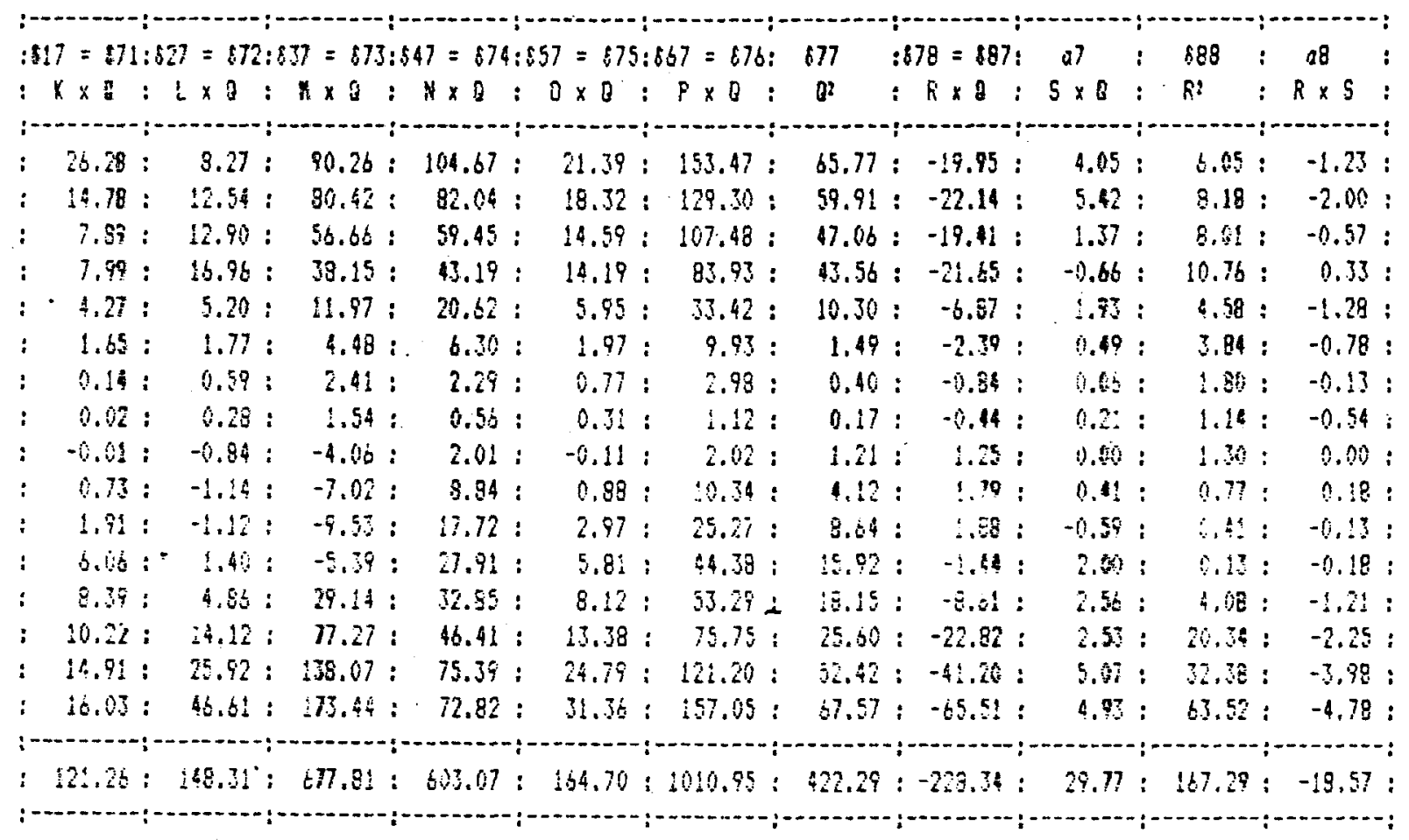


TABEL PERHIIUNGAN SISTEM PERSGMAAN LINIER

\begin{tabular}{|c|c|c|c|c|c|c|c|c|}
\hline & 1 & 2 & 3 & 4 & 5 & $b$ & 7 & 8 \\
\hline 1 & 39.48 & $42,4]$ & 202.64 & 284.71 & 49.74 & 303.37 & 121.26 & -66.75 \\
\hline 2 & 42,43 & 75.07 & 319.84 & 203.87 & 66.98 & 364.09 & 148.31 & -111.35 \\
\hline 3 & 202.64 & 319.84 & 1516.24 & 952.63 & 300.16 & 1653.4 & 677.81 & -491.93 \\
\hline 4 & 184.71 & 203.87 & 952.63 & 917.87 & 243.93 & 1502.62 & 603.07 & -317.8 \\
\hline 5 & 49.74 & $\$ 6.98$ & 300.16 & 243.93 & 70.69 & 411.73 & 164.7 & -102.03 \\
\hline 6 & 303.37 & 364.09 & 1653.4 & 1502.62 & 111.73 & 2501.78 & 1010.95 & -560.11 \\
\hline 7 & 121.26 & 148.31 & 677.81 & 503.07 & 164.7 & 1010.75 & 422.29 & -228.34 \\
\hline 8 & -66.75 & -111.35 & -491.94 & -317.8 & $-102,03$ & -569.11 & -228.34 & 167.29 \\
\hline
\end{tabular}

\begin{tabular}{|c|c|c|c|c|c|c|c|c|c|}
\hline & & 1 & 2 & 3 & 4 & 5 & 6 & 7 & 8 \\
\hline & 1 & 39.48 & 42.43 & 202.64 & 184.71 & 49.74 & 303.37 & 121.26 & -66.75 \\
\hline & 2 & 42.43 & 75.07 & 319.84 & 203.87 & 66.98 & 364.09 & 148.31 & -111.35 \\
\hline & 3 & 202.64 & 319.84 & 1516.24 & $952.6 ?$ & 300.16 & 1653.1 & 677.81 & -491.93 \\
\hline$A=$ & 4 & 184.71 & 203.87 & 952.63 & 917.87 & 243.93 & 1502.62 & 603.07 & -317.8 \\
\hline & 5 & 49.74 & 66.98 & 300.16 & 243.93 & 70.69 & 411.73 & 164.7 & -102.03 \\
\hline & 6 & 303.37 & 364.09 & $165 ? .4$ & 1502.62 & 411.73 & 2501.78 & 1010.95 & -560.11 \\
\hline & 7 & 121.26 & 148.31 & 677.81 & 603.07 & 164.7 & 1010.95 & 422.29 & -228.34 \\
\hline & 8 & -66.75 & -111.35 & -491.94 & -317.8 & $-[02.0\}$ & -560.11 & -228.34 & 167.29 \\
\hline
\end{tabular}

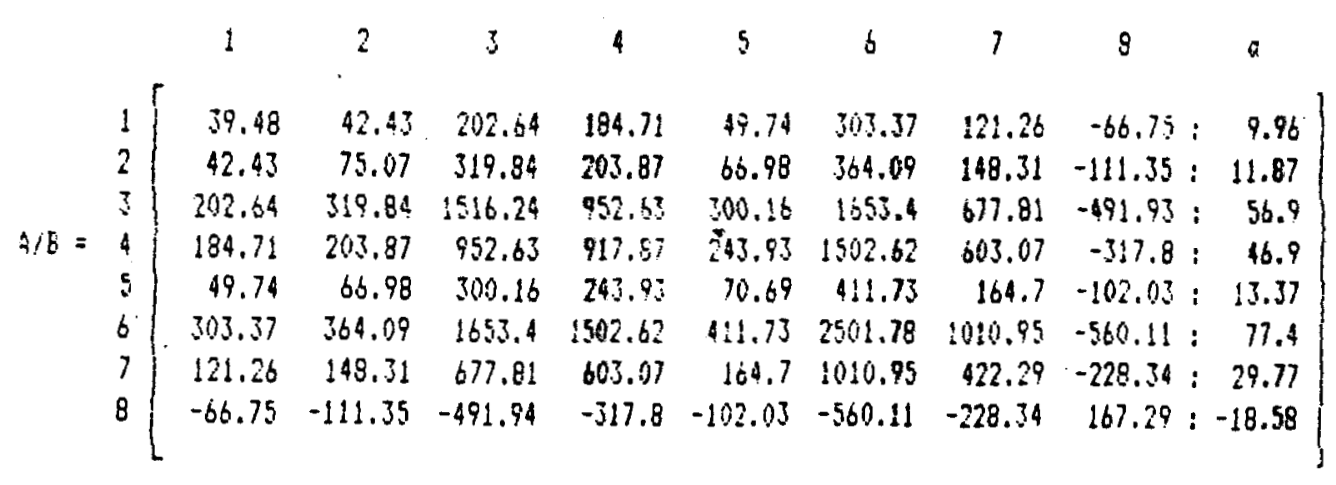

$=8 \quad n=8$ berapa $r(A)=?$ dan $(\mid A / B)=?$ 


\begin{tabular}{|c|c|c|c|c|c|c|c|c|}
\hline & 39.48 & 42.43 & 202.54 & $184.7 !$ & 49.74 & 363.37 & 131.26 & -66.75 \\
\hline B21 $(-12.43 / 39.48)$ & 0 & 29.47 & 102.06 & 55.36 & 13.52 & 38.05 & 17.49 & -39.7 \\
\hline $831(-202.64139 .48)$ & 0 & 102.06 & 476.14 & 4.56 & 44.86 & .29 & 55.42 & -149.74 \\
\hline $842(-184.71139 .48)$ & 0 & 5.36 & 4.56 & 53.69 & 11.22 & 83.28 & 35.75 & $-5,88$ \\
\hline $851(-49.74 / 39.48)$ & 0 & 13,52 & 44.86 & 11.22 & 8.02 & 79.52 & 11.93 & -18.03 \\
\hline $861(-303.37139 .43)$ & 0 & 38.155 & 96.29 & 83.28 & 29.52 & 136.64 & 79.17 & -47.81 \\
\hline $871(-121.26134 .48)$ & 0 & 17.99 & $\$ 5.42$ & 35.75 & 11.93 & 79.17 & 49.85 & -23.57 \\
\hline $881(66.67 / 79.48)$ & 0 & -39.7 & $-49,74$ & -5.88 & -18.03 & -77.81 & -23.57 & 54.7 \\
\hline
\end{tabular}

\begin{tabular}{|c|c|c|c|c|c|c|c|c|}
\hline $812(-42.43 / 29.47)$ & 39.48 & 0 & 55.7 & 176.99 & 30.27 & 268.59 & 95.36 & -9.51 \\
\hline & 0 & 29.47 & 102,06 & 5.36 & 13.25 & $\mathbf{x . 0 5}$ & 17.99 & -39.7 \\
\hline $832(-102.05 / 29.47)$ & 0 & 0 & 122.69 & -14 & -1.96 & -35.48 & -6.88 & -12.25 \\
\hline 842 \& $-5.36 / 29.47$ ) & 0 & 0 & -14 & $\$ 2.72$ & 8.76 & 76.36 & 32,48 & 1.34 \\
\hline $852(-13.52 / 29.47)$ & 0 & 0 & -1.96 & 8.76 & 1.82 & 12.06 & 3.68 & 0.18 \\
\hline $862|-38.05 / 29.47|$ & 0 & 0 & -35.48 & -76.36 & 12.06 & $121.5 !$ & 55.94 & 3.45 \\
\hline $872(-17.99 / 29.47)$ & 0 & 0 & -6.88 & 32.48 & 3.68 & 55.94 & 36.87 & 0.68 \\
\hline $882(39.79 / 29.17)$ & 0 & 0 & -12.25 & 1.34 & 0.18 & 3.45 & 0.66 & 1.22 \\
\hline
\end{tabular}

\begin{tabular}{|c|c|c|c|c|c|c|c|c|}
\hline $013(-55.71122 .69)$ & 39,48 & 0 & 0 & 183.35 & 31.16 & 264.7 & 98.48 & -3.95 \\
\hline $223(-102.06 / 122.69)$ & 0 & 29.47 & 0 & 17 & 15.15 & 67.56 & 23.71 & -29.51 \\
\hline & 0 & 0 & 122.69 & -11 & -1.96 & -35.48 & -6.88 & -12.25 \\
\hline $843(14 / 122.69)$ & (1) & 0 & 0 & 51.22 & 8.54 & n.J1 & 31.69 & -0.06 \\
\hline $853(1.891122 .69)$ & 0 & 0 & 0 & 8.54 & 1.79 & 11.49 & 3.57 & -0.02 \\
\hline$B 63(35.48 / 122.69)$ & 0 & 0 & 0 & 72.31 & 11.49 & 114.25 & 53.95 & -0.09 \\
\hline $873(6.88 / 122.69)$ & ) & 0 & 8 & 31.69 & 3.57 & 53.95 & 38.48 & -0.03 \\
\hline $583112.25 / 122.6$ & 0 & 0 & 0 & -0.06 & -0.02 & -0.09 & -0.03 & -0.003 \\
\hline
\end{tabular}

LAMPIRAN 3 


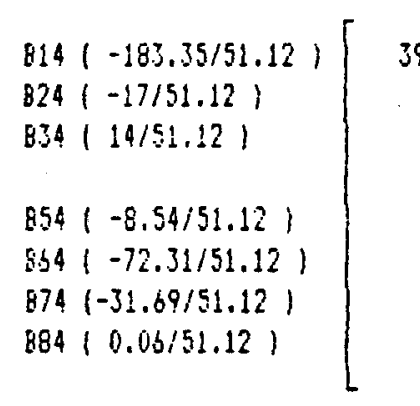

$\left.\begin{array}{rrrrrrrr}39.48 & 0 & 0 & 0 & 0.53 & 5.35 & -15.18 & -3.73 \\ 0 & 29.47 & 0 & 0 & 12.31 & 43.51 & 13.17 & -29.49 \\ 0 & 0 & 122.59 & 0 & 0.38 & -15.68 & 1.8 & -12.27 \\ 0 & 0 & 0 & 51.12 & 8.54 & 72.31 & 31.69 & -0.06 \\ 0 & 0 & 0 & 0 & 0.36 & -0.59 & -1.72 & -0.01 \\ 0 & 0 & 0 & 0 & -0.59 & 8.97 & 9.12 & -0.005 \\ 0 & 0 & 0 & 0 & -1.72 & 9.12 & 18.83 & 0.007 \\ 0 & 0 & 0 & 0 & -0.01 & -0.005 & 0.007 & -0.003\end{array}\right)$

\begin{tabular}{|c|c|c|c|c|c|c|c|c|}
\hline$\cdot$ & 39.48 & 0 & 0 & 6 & 0 & 0.22 & -12.65 & -3.72 \\
\hline$B 25(-12.31 / 0.36)$ & 0 & 29.47 & 0 & -0 & 0 & 63.68 & 71.98 & $-29.15^{\prime}$ \\
\hline $835(-0.38 / 0.36)$ & 0 & 0 & 122.69 & 0 & 0 & -1.5 .06 & 3.32 & -12.26 \\
\hline $845(-8.45 / 0.36)$ & 0 & 0 & .0 & 51.12 & 0 & $8 b .31$ & 72.19 & 0.18 \\
\hline & 0 & 0 & 0 & 0 & 0.36 & -0.59 & -1.72 & -0.01 \\
\hline $865(0.59 / 0.36-)$ & 0 & 0 & 0 & 0 & 0 & 8 & 6.3 & -0.02 \\
\hline $875(1.7210 .36)$ & 0 & 0 & 0 & 0 & 0 & 5.3 & 10.61 & -0.04 \\
\hline $885(0.01 / 0.36)$ & 0 & 0 & 0 & 0 & 0 & -0.02 & -0.04 & -0.05 \\
\hline
\end{tabular}

$816(-6.22 / 8)$
$826(-63.68 / 8)$
$836(15.06 / 8)$
$846(-86.31 / 8)$
$856(0.59 / 8)$
$876(-6.3 / 8)$
$886(0.02 / 8)$$\quad\left[\begin{array}{rrrrrrrr}39.48 & 0 & 0 & 0 & 0 & 0 & -17.55 & -3.7 \\ 0 & 29.47 & 0 & 0 & 0 & 0 & 21.83 & -28.99 \\ 0 & 0 & 122.69 & 0 & 0 & 0 & 15.48 & -12.3 \\ 0 & 0 & 0 & 51.12 & 0 & 0 & 140.46 & -3.58 \\ 0 & 0 & 0 & 0 & 0.36 & 0 & -1.26 & -0.01 \\ 0 & 0 & 0 & 0 & 0 & 0 & 6.3 & -0.02 \\ 0 & 0 & 0 & 0 & 0 & 0 & 5.65 & -2.43 \\ 0 & 0 & 0 & 0 & 0 & 0 & -0.02 & -0.05\end{array}\right]$




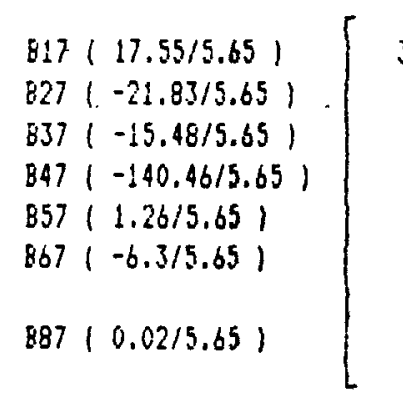

$818(-46.35 / 0.06)$
$828(-19.6 / 0.06)$
$838(-5.64 / 0.06)$
$848(56.83 / 0.06)$
$858(-0.55 / 0.06)$
$868(2.7 / 0.06)$
$878(-2.43 / 0.06)$
$\cdots$

$\operatorname{Jadi} r(A)=8$

Kenudian kita cari $r(A / B)$ :

$\left.\begin{array}{rrrrrrrr}39.49 & 0 & 0 & 0 & 0 & 0 & 0 & -46.35 \\ 0 & 29.47 & 0 & 0 & 0 & 0 & 0 & -19.6 \\ 0 & 0 & 122.69 & 0 & 0 & 0 & 0 & -5.64 \\ 0 & 0 & 0 & 51.12 & 0 & 0 & 0 & 56.83 \\ 0 & 0 & 0 & 0 & 0.36 & 0 & 0 & -0.55 \\ 0 & 0 & 0 & 0 & 0 & 8 & 0 & 2.7 \\ 0 & 0 & 0 & 0 & 0 & 0 & 5.65 & -2.43 \\ 0 & 0 & 0 & 0 & 0 & 0 & 0 & -0.06\end{array}\right)$

39.48
0
0
0
0
0
0
0

$$
\begin{array}{r}
0 \\
0 \\
0 \\
51+2 \\
0 \\
0 \\
0 \\
0
\end{array}
$$

$\begin{array}{rr}0 & 0 \\ 0 & 0 \\ 0 & 0 \\ 0 & 0 \\ 0.36 & 0 \\ 0 & 0 \\ 0 & 0 \\ 0 & 0\end{array}$

$$
|A / 8|=\left[\begin{array}{rrrrrrrrr}
39.48 & 42.43 & 202.64 & 184.71 & 49.74 & 303.37 & 121.26 & -66.75: & 9.96 \\
42.43 & 75.07 & 319.84 & 203.87 & 66.98 & 364.09 & 148.31 & -111.35: & 11.87 \\
202.64 & 319.84 & 1516.24 & 952.63 & 300.16 & 1653.4 & 677.81 & -491.93: & 56.9 \\
184.71 & 203.87 & 952.63 & 917.87 & 243.93 & 1502.62 & 603.07 & -317.8: & 46.9 \\
49.74 & 66.98 & 300.16 & 243.93 & 70.69 & 111.73 & 154.7 & -102.03: & 13.37 \\
303.37 & 364.04 & 1653.4 & 1502.62 & 411.73 & 2501.78 & 1010.95 & -560.11: & 77.4 \\
121.26 & 148.51 & 677.81 & 603.07 & 164.7 & 1010.95 & 422.29 & -228.34: & 29.7 \\
-66.75 & -111.35 & -491.94 & -317.8 & -102.03 & -560.11 & -228.34 & 167.29: & -18.57
\end{array}\right]
$$




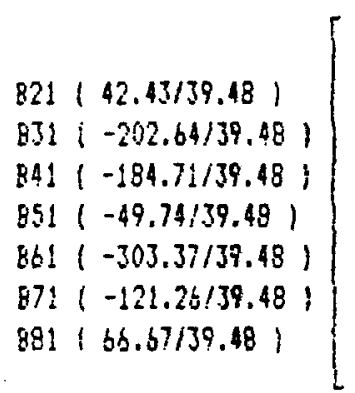

39.48

$$
0
$$

$29.47 \quad 102.07$

$0 \quad 102.06 \quad 475.14$

$0 \quad 5.36 \quad 4.56$

$0 \quad 13.52 \quad 44.86$

o $\quad 38.05 \quad 96.29$

$\begin{array}{lll}0 & 17.99 & 55.42\end{array}$

i) $\quad-39.7 \quad-149.74$
184.71

5.36

4.56

53.69

11.22

83.28

35.75

$-5.88$

$\begin{array}{rrrrrr}49.74 & 303.37 & 121.26 & -66.67: & 9.96 \\ 13.52 & 38.05 & 17.99 & -39.7: & 1.17 \\ 44.86 & 96.29 & 55.42 & -149.74: & 5.79 \\ 11.22 & 33.28 & 35.75 & -5.86: & 0.3 \\ 8.02 & 29.52 & 11.91 & -18.03: & 0.82 \\ 29.52 & 170.54 & 79.17 & -47.81: & 0.87 \\ 11.93 & 79.17 & 19.85 & -23.57: & -0.82 \\ -19.03 & -47.31 & -23.57 & 51.7: & -1.75\end{array}$

\subsection{8}

$\begin{array}{rrr}0 & 55.7 & 176.99 \\ 29.47 & 102.06 & 5.35 \\ 0 & 122.69 & -14 \\ 0 & -14 & 52.72 \\ 0 & -1.96 & 8.76 \\ 0 & -35.49 & 76.36 \\ 0 & -6.80 & 32.49 \\ 0 & -12.25 & 1.34\end{array}$

$30.27 \quad 248.59$

$13.52 \quad 38.45$

$-1.04 \quad 35.88$

8.75 76.35

$1.82 \quad 12.5$

$12.05 \quad 121 . \$$

i.t. 55.54

$0.18 \quad 5.15$
95.3

17.99

$-6.88$

32.49

3.68

55.96

39.87

0.66
$-9.51: 8.28$

$-39.7: \quad 1.17$

$-12.25: 1.73$

$1.34: 0.09$

$4.18 ; 0.28$

$3.45:-0.84$

$0.66:-1.53$

$1.22:-0.17$
$813(-55.70 / 122.69)$ $823(-102.06 / 122.69)$

[143 (14/122.69)

$853(1.96 / 122.69)$

Bb3 $(35.48 / 122.69)$

$873(6.88 / 222.6 ?)$

$883(12.25 / 122.69)$
39.48$$
0
$$

29.47

29.47

0

(1)

0

0

0

0
183.35

17
-14

51.12

8.54

72.31

31.69

$-0.05$
$31.16 \quad 264.7$

$15.15 \quad 67.56$

$-1.96 \quad-35.49$

$8.54 \quad 72.31$

$1.79 \quad 11.49$

11.49111 .25

$-3.575 .55$

$-0.02 \quad-0.09$ $\begin{array}{rrrr}98.48 & -3.95: & 7.49 \\ 23.71 & -29.51: & -0.27 \\ -6.88 & -12.25: & 1.73 \\ 31.69 & -0.06: & 0.29 \\ 3.57 & -0.02: & 0.31 \\ 53.95 & -0.09: & -0.14 \\ 38.48 & -0.03: & -1.43 \\ -0.03 & -0.603: & 0.003\end{array}$

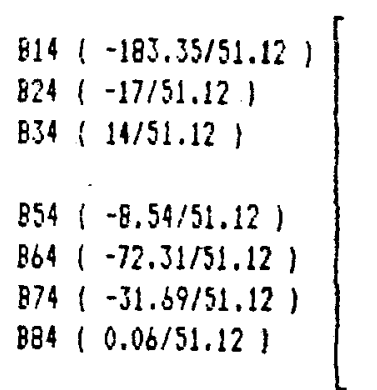

39.48

$$
\begin{array}{r}
3.48 \\
0 \\
0 \\
0 \\
0 \\
0
\end{array}
$$

$\begin{array}{rr}0 & 0 \\ 29.47 & 0 \\ 0 & 122.69 \\ 0 & 0 \\ 0 & 0 \\ 0 & 0 \\ 0 & 0 \\ 0 & 0\end{array}$

$\begin{array}{rrr}0 & 0.53 & 5.35 \\ 0 & 12.31 & 43.51 \\ 0 & 0.38 & -15.68 \\ 51.12 & 9.54 & 72.31 \\ 0 & 0.36 & -0.59 \\ 0 & -0.59 & 8.97 \\ 0 & -1.72 & 9.12 \\ 0 & -0.01 & -0.005\end{array}$




\begin{tabular}{|c|c|c|c|c|c|c|c|c|c|}
\hline & & & & & & & & : & \\
\hline $815(-0.53 / 0.36)$ & 39.48 & 0 & 0 & 0 & 0 & 6.22 & -12.65 & $-3.72:$ & 6.07 \\
\hline $825|-12.31 / 0.36|$ & 0 & 29.47 & 0 & 0 & 0 & 63.68 & 71.98 & $-29.15:$ & -9.26 \\
\hline $835(-0.38 / 0.36)$ & 0 & 0 & 122.69 & .0 & 0 & -15.06 & 3.62 & -12.26 ; & 1.54 \\
\hline \multirow[t]{2}{*}{$845(-8.54 / 0.36)$} & 0 & 0 & 0 & 51.12 & 0 & 86.31 & 72.49 & $0.18:$ & -5.88 \\
\hline & 0 & 0 & 0 & 0 & 0.36 & -0.59 & -1.72 & $-0.01:$ & 0.26 \\
\hline $865 \mid 0.59 / 0.36)$ & 0 & 0 & 0 & 0 & 0 & 8 & 6.3 & $-0.02:$ & -0.12 \\
\hline$B 75(1.7210 .36)$ & 0 & 0 & 0 & 0 & 0 & 6.3 & 10.61 & $-0.04:$ & -0.37 \\
\hline B35 $(0.0110 .36)$ & 0 & 0 & 0 & 0 & 0 & -0.02 & -0.04 & $-0.003:$ & 0.01 \\
\hline
\end{tabular}

\begin{tabular}{|c|c|c|c|c|c|c|c|c|c|}
\hline & & & & & & & & : & \\
\hline $816(-6.22 / 9)$ & 39.48 & 0 & 0 & -0 & 0 & 0 & -17.55 & $-3.7:$ & 6.61 \\
\hline $826(-63.68 / 8)$ & 0 & 29.47 & $\cdot 0$ & 0 & 0 & 0 & 21.83 & $-28.99:$ & -8.3 \\
\hline $836 \mid 15.06 / 8)$ & 0 & 0 & 122.69 & 0 & 0 & 0 & 15.48 & $-12.3:$ & 1.31 \\
\hline$B 46(-86.31 / 8)$ & 0 & 0 & 0 & 51.12 & 0 & 0 & 4.52 & $0.4:$ & -4.59 \\
\hline $856(0.59 / 8)$ & 0 & 0 & 0 & 0 & 0.36 & 0 & -1.26 & $-0.01:$ & 0.25 \\
\hline & 0 & 0 & 0 & 0 & 0 & s & b. 3 & $-0.02:$ & -0.12 \\
\hline $876|-6.3 / 8|$ & 0 & 0 & 0 & 0 & 0 & 0 & 5.65 & $-0.02:$ & -0.28 \\
\hline $88 b(0.0218)$ & 0 & 0 & 0 & 0 & 0 & 4 & -0.02 & $-0.003:$ & 0.01 \\
\hline
\end{tabular}

\begin{tabular}{|c|c|c|c|c|c|c|c|c|c|}
\hline & & & & & & & & 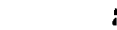 & \\
\hline $817(17.55 / 5.65)$ & 39.48 & 0 & 0 & 0 & 0 & 0 & 0 & -3.76 & 5.29 \\
\hline $827 \mid-21.83 / 5.65)$ & $\dot{0}$ & 29.47 & 0 & 0 & 0 & 0 & 0 & -28.9 & -7.22 \\
\hline $837(-15.48 / 5.65)$ & 0 & 0 & 122.69 & 0 & 0 & 0 & 0 & -12.25 & 2.08 \\
\hline $847(-4.52 / 5.56)$ & 0 & 0 & 0 & 51.12 & 0 & 0 & 0 & 0.12 & -4.37 \\
\hline $857(1.26 / 5.65)$ & 0 & 0 & 0 & 0 & 0.36 & 0 & 0 & -0.01 & 0.19 \\
\hline $667(-6.3 / 5.65)$ & $\theta$ & 0 & 0 & 0 & $=0$ & 8 & 0 & 0.002 & 5.19 \\
\hline & 0 & 0 & 0 & 0 & 0 & 0 & 5.65 & -0.02 & -0.28 \\
\hline $8 B 7(0.02 / 5.65)$ & 0 & 0 & ) & 0 & 0 & 0 & $\hat{0}$ & -0.003 & 0.01 \\
\hline
\end{tabular}




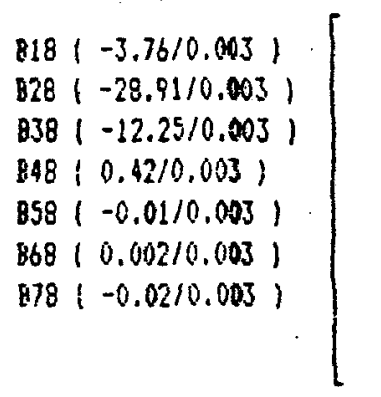

$\begin{array}{rr}39.48 & 0 \\ 0 & 29.47 \\ 0 & 0 \\ 0 & 0 \\ 0 & 0 \\ 0 & 0 \\ 0 & 0 \\ 0 & 0\end{array}$

$\left.\begin{array}{rrrrrrr}0 & 0 & 0 & 0 & 0 & 0: & -7.24 \\ 0 & 0 & 0 & 0 & 0 & 0:-103.59 \\ 122.69 & 0 & 0 & 0 & 0 & 0:-38.75 \\ 0 & 51.12 & 0 & 0 & 0 & 0: & -2.97 \\ 0 & 0 & 0.36 & 0 & 0 & 0: & 0.16 \\ 0 & 0 & 0 & 8 & 0 & 0: & 0.2 \\ 0 & 0 & 0 & 0 & 5.65 & 0: & -0.35 \\ 0 & 0 & 0 & 0 & 0 & -0.003: & 0.01\end{array}\right)$.

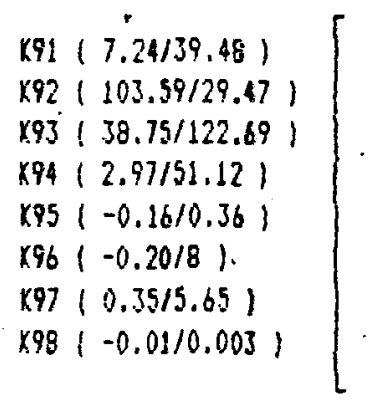

39.48
0
0
0
0
0
0
0

0
29.47
0
0
0
0
0
0

0
0
122.69
0
0
0
0
0

0
-0
0
51.12
0
0
0
0

0
0
0
0
0.36
0
0
0

0
0
0
0
0
8
0
0

$$
\left.\begin{array}{rrr}
0 & 0: & 0 \\
0 & 0: & 0 \\
0 & 0: & 0 \\
0 & 0: & 0 \\
0 & 0: & 0 \\
0 & 0: & 0 \\
5.65 & 0: & 0 \\
0 & -0.003: & 0
\end{array}\right]
$$

Jadi $r(A / B)=8$

sehingga $r|A|=r|A / B|=n=8$,

aka persaaan tersebut eampunyai penyelesaian tunggal!

sehingga atrik:

$\left[\begin{array}{rrrrrrrrr}39.48 & 42.43 & 202.64 & 184.71 & 49.74 & 303.37 & 121.26 & -66.75: & 9.96 \\ 42.43 & 75.07 & 319.84 & 203.87 & 66.98 & 364.09 & 169.31 & -111.35: & 11.87 \\ 202.64 & 319.84 & 1516.24 & 952.63 & 300.16 & 1653.4 & 677.81 & -491.93: & 56.9 \\ 184.71 & 203.87 & 952.63 & 917.87 & 243.93 & 1502.62 & 617.07 & -317.8: & 46.9 \\ 49.74 & 66.98 & 300.16 & 243.93 & 70.69 & 411.73 & 144.7 & -102.03: & 13.37 \\ 303.37 & 364.09 & 1653.4 & 1502.62 & 411.73 & 2502.78 & 1010.95 & -560.11: & 77.1 \\ 121.26 & 148.31 & 677.81 & 603.07 & 164.7 & 1010.95 & 42.29 & -228.34: & 29.77 \\ -66.75 & -111.35 & -491.94 & -317.8 & -102.03 & -560.11 & -271.34 & 167.29: & -18.59\end{array}\right]$




\begin{tabular}{|c|c|c|c|c|c|c|c|c|c|}
\hline & 39.49 & 42.43 & 202.64 & 184.71 & 49.74 & 303.37 & 121.26 & $-66,67:$ & 9,96 \\
\hline $821(42.43 / 39.48)$ & 0 & 29.47 & 102.07 & 5.36 & 13.52 & 38.05 & 17.99 & $-39.7:$ & 1.17 \\
\hline $531(-202.64 / 39.48)$ & 0 & 102.08 & 476.14 & 4.56 & 44,86 & 96.29 & 55.42 & $-149.74:$ & 5.78 \\
\hline $841(-184,71 / 39,48)$ & 0 & 5.36 & 4.56 & 53.69 & 11.22 & 83.28 & 35.75 & $-5.88:$ & 0.3 \\
\hline $851(-49.74139 .48)$ & 0 & 13.52 & 44.86 & 11.22 & 8.02 & 29.52 & 11.93 & $-18.03:$ & 0.82 \\
\hline $851(-303.37139 .18)$ & 0 & 38.05 & 96.29 & 83.28 & 29.52 & 170.64 & 79.17 & $-47.81:$ & 0.87 \\
\hline $871(-121.26 / 39.48)$ & 0 & 17.99 & 55.12 & 35.75 & 11.93 & 79.17 & 49.85 & $-23.57 i$ & -0.82 \\
\hline $881(66.67 / 39.48)$ & 0 & -39.7 & $-\$ 19.74$ & -5.88 & -18.03 & -17.81 & -23.57 & $54.7:$ & -1.75 \\
\hline
\end{tabular}

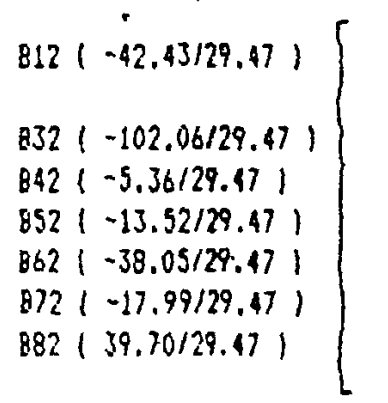

39.48

$$
\begin{array}{rr}
0 & 55.7 \\
29.47 & 107.06
\end{array}
$$

102.06

122.69

$-14$

$-1.96$

$-35.48$

$-6.88$

$-12.25$
176.99
3.36
-14
52.72
0.76
76.36
32.18
1.34

30.27

13.52

-1.96
8.76

1.82

12.06

3.60

3.68

0.18
248.59

38.45

35.48

76.36

12.06

121.51

55.94

3.45
95.36

17.99

$-6.88$

32.48

3.68

55.94

38.87

0.66

$\left.\begin{array}{rl}-9.51: & 0.28 \\ -39.7: & 1.17 \\ -12.25: & 1.73 \\ 1.34: & 0.09 \\ 0.18: & 0.28 \\ 3.45: & -0.64 \\ 0.66: & -1.53 \\ 1.22: & -0.17\end{array}\right\}$

39.48

$$
\begin{array}{rrr}
0 & 0 & 183.35 \\
29.47 & 0 & 17 \\
0 & 122.69 & -14 \\
0 & 0 & 51.12
\end{array}
$$

31.16

15.15

$-1.9 b$

8.54

1.79

11.49

$-3.57$

$-0.02$
264.7
67.56
-35.49
72.31
11.49
111.25
53.95
-0.09

98.

$-6.88-12.25: 1.73$

$31.69-0.06: 0.29$

$3.57 \quad-0.02: 0.31$

$53.95-0.09 ;-0.14$

$38.48-0.03:-1.43$

$-0.03-0.003: 0.003$
$23.71-29.51:-0.27$

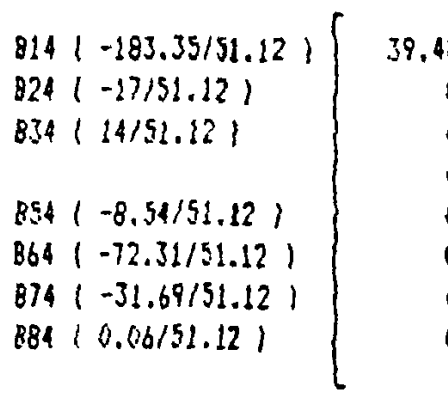

$$
\begin{array}{rr}
0 & \\
29.47 & \\
0 & 122.69 \\
0 & \\
0 & \\
0 & \\
0 & \\
0 &
\end{array}
$$

$$
5 ! .12
$$

0.53

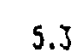

5.35
43.5

12.31

0.38

$-15.69$

72.31

0.36

$-0.59$

8.97

9.12

$-0.005$

$$
\begin{array}{rrr}
-15.18 & -3.73: & 0.45 \\
13.37 & -29.49: & -0.37 \\
1.8 & -12.27: & 1.81 \\
31.69 & -0.06: & 0.29 \\
-1.32 & -0.01: & 0.26 \\
9.12 & -0.005: & -0.55 \\
18.83 & 0.007: & -1.61 \\
0.007 & -0.003: & 0.003
\end{array}
$$




\begin{tabular}{|c|c|c|c|c|c|c|c|c|c|}
\hline & & & & & & & & ' & \\
\hline $815(-0.53 / 0.36)$ & 39.48 & 0 & 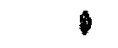 & 0 & 0 & 6.22 & -12.65 & $-3.72:$ & 6.07 \\
\hline $325(-12.31 / 0.36)$ & 0 & 29.47 & $\vartheta$ & 0 & 0 & 63.68 & 71.98 & $-29.15 ;$ & -9.26 \\
\hline $835(-0.38 / 0.36)$ & 0 & 0 & 122.69 & 0 & 0 & -15.06 & 3.62 & $-12.26:$ & 1.54 \\
\hline \multirow{2}{*}{$845(-8.54 / 0.36)$} & 0 & 0 & 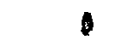 & 51.12 & 0 & 86.31 & 72.49 & 0.18 ; & -3.88 \\
\hline & 0 & 0 & 0 & 0 & 0.36 & -0.59 & -1.72 & $-0.01:$ & 0.28 \\
\hline $865(0.5910 .36)$ & 0. & 0 & $\bullet$ & 0 & 0 & 8 & 6.3 & $-0.02:$ & -0.12 \\
\hline $075\{1.72 / 0.36\}$ & 0 & 0 & 1 & 0 & 0 & 6.3 & $10.61^{\prime}$ & $-0.04:$ & -0.37 \\
\hline $885(0.01 / 0.36)$ & 0 & 0 & 1 & 0 & 0 & -0.02 & -0.04 & $-0.003:$ & 0.01 \\
\hline
\end{tabular}

$816(-6.22 / 8)$
$826(-53.68 / 8)$
$836(15.06 / 8)$
$846(-85.31 / 8)$
$856(0.5918)$
$876(-6.318)$
$886(0.0218)$$\quad\left[\begin{array}{rrrrrrrrr}39.48 & 0 & 0 & -0 & 0 & 0 & -17.55 & -3.7: & 6.61 \\ 0 & 29.47 & 0 & 0 & 0 & 0 & 21.83 & -28.99: & -8.3 \\ 0 & 0 & 122.69 & 0 & 0 & 0 & 15.48 & -12.3: & 1.31 \\ 0 & 0 & 0 & 51.12 & 0 & 0 & 4.52 & 0.4: & -4.59 \\ 0 & 0 & 0 & 0 & 0.36 & 0 & -1.26 & -0.01: & 0.25 \\ 0 & 0 & 0 & 0 & 0 & 8 & 6.3 & -0.02: & -0.12 \\ 0 & 0 & 0 & 0 & 0 & 0 & 5.65 & -0.02: & -0.28 \\ 0 & 0 & 0 & 0 & 0 & 0 & -0.02 & -0.003: & 0.01\end{array}\right)$

\begin{tabular}{|c|c|c|c|c|c|c|c|c|c|}
\hline & & & & & & & & : & \\
\hline $817(17.55 / 5.65)$ & 39.48 & 0 & 0 & 0 & \% & 0 & 0 & -3.76 & 5.29 \\
\hline $827 \mid-21.83 / 5.65\}$ & 0 & 29.47 & 0 & 0 & 0 & 0 & 9 & $-28.9:$ & -7.22 \\
\hline $837(-15.48 / 5.65)$ & 0 & 0 & 122.69 & 0 & 0 & 0 & 0 & -12.25 & 2.08 \\
\hline 84) $(-4.52 / 5.56)$ & 0 & 0 & 0 & 51.12 & 0 & 0 & 0 & 0.12 & -4.37 \\
\hline $857(1.26 / 5.65)$ & 0 & 0 & 0 & 0 & 0.36 & 0 & 0 & -0.01 & 0.19 \\
\hline $867(-6.3 / 5.65)$ & 0 & 0 & 0 & 0 & -0 & 8 & 0 & $0.002:$ & 0.19 \\
\hline & 0 & 0 & 0 & 0 & 0 & 0 & 5.65 & -0.02 & -0.28 \\
\hline $887\{0.02 / 5.65\}$ & 0 & 0 & 0 & 0 & 0 & 0 & 0 & -0.003 & $0.0 p^{*}$ \\
\hline
\end{tabular}


SAMBUNGAN LAMPIRAN 3

\begin{tabular}{|c|c|c|c|c|c|c|c|c|c|}
\hline & & & & & & & & & \\
\hline $018(-3.76 / 0.003)$ & 39.48 & 0 & 0 & 0 & 0 & $t$ & 0 & 0 & -7.24 \\
\hline $828(-28.91 / 0.003)$ & 0 & 29.47 & 0 & 0 & 0 & 0 & 0 & 0 & -103.59 \\
\hline B.38 $(-12.25 / 0.003)$ & 0 & 0 & 122.89 & 0 & 0 & $\theta$ & 0 & 0 & -38.75 \\
\hline $848 \div 0.42 / 0.003)$ & 0 & 0 & 0 & 51.12 & 0 & 0 & 0 & 0 & -2.97 \\
\hline $858(-0.0210 .003)$ & 0 & 8 & 0 & 0 & 0.36 & 0 & 0 & 0 & $: 0.16$ \\
\hline $068(0.002 / 0.003)$ & 0 & 0 & 0 & 0 & 0 & 8 & 0 & 0 & 0.2 \\
\hline $878(-0.02 / 0.003)$ & 0 & 0 & 0 & 0 & 0 & 0 & 5.65 & 0 & -0.35 \\
\hline & 0 & 0 & .0 & 0 & 0 & 0 & 0 & -0.003 & 0.01 \\
\hline
\end{tabular}

Dari perhitungan diatas dapat diferoleh hasil:

\begin{tabular}{|c|c|c|c|c|c|}
\hline 39.48 & $81=-7.24$ & $\$ 1=-0.1$, & 0.36 & $B 5=2.16$ & $B S=0.44$ \\
\hline 29.47 & $82=-103.59$ & $B 2=-3.5$, & 8 & $B 6=0.20$ & $16=0.03$ \\
\hline 122.69 & $33=-36.75$ & $B 3=-0.3$ & 5.65 & $87=-0.35$ & $87=-4.06$ \\
\hline 31.12 & $84=-2.97$ & $84=-0.0$, & 0.003 & $18=0.62$ & $18=-3.33$ \\
\hline
\end{tabular}

